\title{
Tabularia
}

TABULARIA Sources écrites des mondes normands médiévaux

\section{The Acta archiepiscoporum Rotomagensium: study and edition}

Les Acta archiepiscoporum Rotomagensium : étude et édition

\section{Richard Allen}

\section{(2) OpenEdition}

\section{Journals}

Electronic version

URL: http://journals.openedition.org/tabularia/2531

DOI: $10.4000 /$ tabularia. 2531

ISSN: $1630-7364$

\section{Publisher:}

CRAHAM - Centre Michel de Boüard, Presses universitaires de Caen

\section{Electronic reference}

Richard Allen, «The Acta archiepiscoporum Rotomagensium: study and edition», Tabularia [Online], Sources en ligne, Online since 18 December 2009, connection on 19 April 2019. URL : http:// journals.openedition.org/tabularia/2531 ; DOI : 10.4000/tabularia.2531 


\title{
The Acta archiepiscoporum Rotomagensium: study and edition ${ }^{1}$
}

\section{Les Acta archiepiscoporum Rotomagensium: étude et édition}

\author{
Richard ALLEN \\ St John's College, Oxford \\ richard.allen@sjc.ox.ac.uk
}

\begin{abstract}
:
This article edits and analyses the Acta archiepiscoporum Rotomagensium. Written by an anonymous clerk of Rouen cathedral towards 1070, this short text was reviewed and augmented twenty years later by Theoderic, a monk of Saint-Ouen de Rouen, who used the $A A R$ to promote an alternative history of the archbishops of Rouen. The following not only presents the first critical edition, and an English translation, but also a discussion of the history of the text and the archdiocese which produced it.
\end{abstract}

Keywords: Acta archiepiscoporum Rotomagensium, John of Ivry, archbishop of Rouen, gesta episcoporum, Theoderic, monk of Saint-Ouen de Rouen.

Résumé:

Cet article édite et analyse les Acta archiepiscoporum Rotomagensium. Rédigé de manière anonyme à la cathédrale de Rouen vers 1070, ce petit texte a été 20 ans plus tard revu et augmenté par Thierry, moine de Saint-Ouen de Rouen, ce dernier ayant utilisé les AAR pour promouvoir une histoire des archevêques différente. L'article suivant présente non seulement la première édition critique, et une traduction anglaise, mais également une discussion de l'histoire du texte et de l'archidiocèse qui l'a produit.

Mots-clés: Acta archiepiscoporum Rotomagensium, Jean d'Ivry, archevêque de Rouen, gesta episcoporum, Thierry, moine de Saint-Ouen de Rouen.

The Acta archiepiscoporum Rotomagensium (henceforth $A A R$ ), as this text is commonly known, is a short history of the archbishops of Rouen from the foundation of the see to the archiepiscopate of William Bona Anima (1079-1110).

1. The author is indebted to Pierre Bauduin, Véronique Gazeau and Stephen Marritt, who read earlier drafts of this article. Any errors that remain, of course, are entirely my own. Thanks must also go to Roger Green and Karla Pollmann, who patiently answered queries regarding the quotations from De civitate Dei, and to the staff of the Bibliothèque municipale de Rouen, who provided me with colour reproductions of the relevant folia of the two manuscripts that contain the $A A R$.

Tabularia «Documents», n 9, 2009, p. 1-66, 18 décembre 2009 http://www.unicaen.fr/mrsh/craham/revue/tabularia/print.php?dossier=sources\&file=09allen.xml 
Classified as a gesta episcoporum ${ }^{2}$, the text is the last of three historiographical works produced by the cathedral chapter of Rouen in the eleventh century, the others being a set of annals and a metrical chronicle in elegiac distiches ${ }^{3}$. A key base resource for the history of the church of Rouen, and fundamental to our understanding of the ecclesiastical history of ducal Normandy, editions of the $A A R$ have, until now, remained confined to scattered and outdated seventeenth- and eighteenth-century collections. In a period infamous for its paucity of sources, especially those produced by the secular church, this apparent neglect is somewhat surprising. The $A A R$ is one of only two works of this genre produced by a Norman cathedral chapter during the ducal period ${ }^{4}$, and its importance as a text means that historians both medieval and modern have relied upon it ${ }^{5}$. A new edition of the $A A R$, therefore, not only makes this essential resource more accessible, but an analysis of it also allows us to better understand circumstances in the archdiocese as it entered a period of reform, and the means by which it hoped to define both its own history and the religious heritage of the region. Since the $A A R$ was also copied and augmented by a monk of Saint-Ouen de Rouen towards 1090, it is also fundamental to our understanding of the rivalry that existed between this house and the cathedral of Rouen during the second half of the eleventh century. The individual responsible for this copy also worked anonymously, but can now be identified as the monk Theoderic. He used the $A A R$ to promote an entirely different history of the archbishops, and sought in particular to tarnish the reputation of Archbishop John of Ivry $(1067-1079)^{6}$, with whom the monks had come into conflict. It is his account of this discord that has, in the past, drawn most scholars to the text, and it has become, in the well-known words of Michel de Boüard, "un incident héroïcomique souvent narré" 7 .

2. Sот, 1981, p. 13 .

3. The annals have only been edited once before, from a manuscript now lost, Chronicon Rotomagense, in LABBÉ, 1657 , i, p. 364-39o. The Metrical chronicle has never been edited and published in full, although it is often incorrectly cited as being printed in MARTÈNE, 1700, part II, p. 248250. Martène only printed the distiches dedicated to William Bona Anima and his successors to Peter de Collemezzo (1237-1245). These can be found in the Livre noir (Bibl. mun. Rouen, ms Y 41 Omont 1406, fol. 14v), and differ from those in the Livre d'ivoire (Bibl. mun. Rouen, ms Y 27 Omont 1405, p. 39-40). Orderic Vitalis incorporated the poem into his work (OV, iii, p. 50-94), although the last verse is his own composition. An unpublished version including all interpolations can be found in VioletTe, 1994, ii, p. 449-454.

4. The other is the so-called Gesta Gaufridi, which was written at Coutances during the reign of Henry I (1100-1135), Gallia Christiana, 1865-1870, xi, Instr., cols. 217-224. Unlike the AAR, all medieval copies of this text have been lost, and the earliest now surviving is partial and dates from the sixteenth century, BnF, ms lat. 10068, fol. 101r-104r. For discussion of the Gesta Gaufridi, see JACQUELINE, 1980, p. 227-239. For an unpublished critical edition, with a French translation, see Devos, 2007, p. 42-68.

5. It appears that Orderic Vitalis used the $A A R$ while writing certain sections of his history, $O V$, i, p 6o; iii, p. xxvi.

6. For his career, see AlLen, (forthcoming; early view).

7. BOÜARD, 1959a, p. 176 
Although the $A A R$ is written as a continuous narrative, its contents can be roughly divided into four sections. Having opened with a brief prologue describing the ecclesiastical province, the first details the careers of the early archbishops from the foundation of the see to the sixth century. Of greatest interest is a discussion concerning the primacy of St. Nicasius as first bishop of Rouen, which was inserted into the second version of the text written at the abbey of SaintOuen. There are few historical details, however, and at times the work is little more than a list of names. The second section begins with an account of the deposition and murder of St. Pretextatus (567-577 and 584-586), which is adapted from that found in Gregory of Tours' Decem libri historiarum ${ }^{8}$, and concludes with a note on Archbishop Franco, the alleged baptiser of the first Norman duke, Rollo. The third section records the careers of the Norman archbishops, including a lengthy development on Archbishop Maurilius (1055-1067), and ends with a note on his successor, John of Ivry.

The final section is comprised of a lengthy account of a violent confrontation between John of Ivry and the monks of Saint-Ouen, which occurred on 24 August 1073. Like the development on Nicasius noted above, it was written by Theoderic of Saint-Ouen in a second version of the $A A R$. The tumult itself occurred after John, who was supposed to conduct the feast day Mass of St. Ouen, arrived at the abbey late and found that proceedings had started without him. Clearly feeling that his jurisdiction had been undermined, the archbishop flew into a rage. He excommunicated the monks on the spot, and drove the officiating prelate, the abbot of Saint-Martin de Sées, from the altar, placing him under an interdict. He then began to celebrate Mass himself, but was interrupted when someone offended by his behaviour began to ring the monastery bell. The individual responsible then ran to the square, and shouted that John was trying to take the relics of St. Ouen-he was not-back to the cathedral. Enraged, the people of Rouen entered the church and attacked the archbishop. The cathedral clerks and Saint-Ouen monks soon began to brawl, and the situation only dissipated with the arrival of the local vicomte. The vivid description of such an event, and its aftermath, has understandably held a certain attraction for scholars, and the account is important not only for the historical information it relates, but also the fascinating insight it provides into episcopal-monastic relations in this period. The final paragraph, which also appears only in the abbey version of the text, is comprised of a short biographical note on William Bona Anima.

\section{Manuscripts}

The AAR survives in two eleventh-century manuscripts. The possible existence of a lost third is also discussed.

A = Rouen, Bibliothèque municipale, ms Y 27 Omont 1405, p. 26-36. It is a manuscript belonging to the cathedral, which is known from its finely carved

8. KRUSCH, 1937, p. 216-225, 337-338, 397-400. 
cover as the Livre d'ivoire. The codex was not bound together until the thirteenth century, with some documents inserted as late as the eighteenth ${ }^{9}$. The AAR covers ten pages of the collection, both recto and verso, and is entitled on the first page by an early modern hand Cathalogus archiepiscoporum Rothomagensium. The text has some rudimentary illumination. The first letter of the first word is an illuminated initial, and certain letters throughout the text have also been rubricated. This begins quite regularly at first, but stops at the bottom of page twentyseven and only resumes rather infrequently from page thirty-three onwards.

Two different hands are responsible for the text of the $A A R$. The first is found only on the opening page. It is distinguished by its lower case single-story " $\mathrm{g}$ ", whose tail is topped with an angled crossbar, and its z-shaped " $r$ ", which is used after the letter "o" (fig. 1). Outside its use in the abbreviation for "-rum/-run", the latter of these features appears only once (the auctoritatis of page twentyeight) in the second hand, which is responsible for the rest of the text. The lowercase "g" of the second hand is also much thinner in form, and usually of the two-story variety (fig. 2). The ink of the first page is much darker than the light brown text found on the other ten, although their faded appearance may simply be the result of exposure to sunlight. The last word of the AAR (disciplinis) is also written in darker ink than the majority of the text, making the letters slightly bolder. It has been conjectured that this is the result of another hand ${ }^{10}$, although this remains controversial ${ }^{11}$. The manuscript has, at some point in its life, been in contact with a partisan of York in the York-Canterbury primacy dispute, for the words et primatem Anglorum have been carefully erased from a sentence concerning Lanfranc of Bec. It is impossible to identify the perpetrator, although a number of cathedral dignitaries in the ducal period had been associated with the church of York ${ }^{12}$. The text's margins also contain notes made in two later medieval hands. The first, which is of the fourteenth/fifteenth century, has written and numbered the names of each archbishop beside the passages corresponding to them ${ }^{13}$. The second, which is of the eleventh or early twelfth century, has written the words "Mihi autem" next to the passage recording how Archbishop Maurilius restored certain religious rites to the church ${ }^{14}$. It is possible that this is a reference to the Introit antiphon of the same name, and therefore records one of the rites that the archbishop was remembered within the cathedral com-

9. Sauvage, 1891, p. 422; Lifshitz, 1990, p. 338 n. 8; Violette, 1997 a, p. 117.

10. Lifshitz, 1990, p. 339.

11. Violette, 1997a, p. 126 n. 46.

12. The best suspect is Ralph de Warneville, treasurer of York (1167-1181) and Rouen (1146-1172), archdeacon of Rouen (1170-1181), chancellor to Henry II and finally bishop of Lisieux (1181-1191). Although the primacy dispute erupted again during his lifetime, there is no evidence that he was involved at any level, or held a strong opinion on the matter. Other Rouen clerks with York ties include the subchanter Robert de Scola, the canons Robert Magnus and Jeremy II, and the precentor (of York) William of Eu. For details, see SpEAR, 2006, p. 214, 219, 222, 226 and 246, and GreENWAY, 1999, p. 14, 18, 22-23, 37 and 41.

13. These sometimes include epithets, such as Malgerius malus or Maurilius monachus, Bibl. mun. Rouen, ms Y 27 Omont 1405, p. 33 (marginalia).

14. Bibl. mun. Rouen, ms Y 27 Omont 1405, p. 35 (marginalia). 
munity for having revived ${ }^{15}$. The text of the $A A R$ is immediately followed by the Metrical chronicle of the archbishops ${ }^{16}$, which is written in a different hand and was composed during the archiepiscopate of Maurilius ${ }^{17}$. The AAR in this manuscript ends with a note on John of Ivry, and as it does not mention his death was probably written during his archiepiscopate, perhaps c. 1070.

$\mathrm{B}=$ Rouen, Bibliothèque municipale, ms Y 41 Omont 1406, fol. 1r-11r. This is an hagiographical dossier belonging to the abbey of Saint-Ouen de Rouen, which is known as the Livre noir. The text of the $A A R$, which covers just over eleven folia, is entitled in an early modern hand Historia archiepiscoporum Rothomagensium. The presentation is far neater than that of the Livre d'ivoire, and the text is written in a regular hand until folio $9 \mathrm{r}$, when the script becomes noticeably different. Although it has been argued that it is the work of one scribe not all have been convinced that this is the case ${ }^{18}$, and it will be demonstrated below that as many as three different hands are to be found. It too has some rudimentary illumination, the text being interspersed with red, green and dark brown initials. This ceases on folio $8 \mathrm{r}$, just two folios before the ink becomes darker and the hand more angular. This version is concordant with that in the Livre d'ivoire insofar as it opens with the description of the ecclesiastical province and the episcopate of St. Mallonus, but it includes shortly thereafter a development on St. Nicasius, who is alleged to be the founder of the episcopal seat. The text of the Livre noir version also differs in that, after the five eulogistic lines devoted to John of Ivry, it continues with the account of the dispute between this prelate and the monks of Saint-Ouen.

A number of factors have been used to date the text. The codex in which it is found is the result of a single scriptorium at a single time, and contains the hands of perhaps as few as three different scribes. Geneviève Nortier dated it (and by consequence the $A A R$ ) to the abbatiate of Nicholas (1042-1092), based on the presence of an anathema written in his name on folio $23 \mathrm{v}^{19}$, while Felice Lifshitz further narrowed the date to between 1090 and c. $1093^{20}$. The fact that this version of the $A A R$ ends with a note on William Bona Anima, who is qualified as the bishop domnus, suggests that the author probably wrote during his archiepiscopate ${ }^{21}$. As with the version in the Livre d'ivoire, a copy of the Metrical chronicle follows the $A A R$ in the Livre noir, but unlike its diocesan counterpart, which places this work immediately after the $A A R$, there are two blank pages between the texts. The verses dedicated to archbishops Geoffrey Brito (1111-1128) through Peter II de Collemezzo (1237-1245) also differ from those found in the Livre d'ivoire.

$\mathbf{M}=$ The lost manuscript of Dom Le Tellier. According to the editors of the Histoire littéraire de la France, Edmond Martène produced his edition of the

15. Mihi autem was the traditional introit for apostolic feasts, HESBERT, 1935, p. 136-139, 162-163, 168169. For Maurilius' own liturgical treatise, the Enchiridion, see Delamare, 1923, p. xlviii-lvii.

16. Bibl. mun. Rouen, ms Y 27 Omont 1405, p. 36-40.

17. For discussion of this text, see Violette, 1994, p. 109-130.

18. SHOPKOW, 1997, p. 282.

19. Nortier, 1971, p. 186.

20. Lifshitz, 1990, p. 337.

21. Violette, 1997a, p. 115. 
$A A R$, details of which are below, from a manuscript belonging to Dom Le Tellier, grand-prior of the abbey of Saint-Ouen ${ }^{22}$. Their comments are noteworthy enough to be reprinted in full here:

Dom Mabillon qui a publié ces Actes des Archevêques de Rouen, les avoit tirés de l'original même de l'Auteur. Après ce premier Editeur, Dom Martène les a réimprimés de noveau, sur un manuscrit de Dom le Tellier grand-Prieur de l'abbaïe de S. Ouen: manuscrit qui selon toute apparence n'est autre que le précédent, ou une copie de celui-ci. Toute la plus grand difference qu'il y a entre l'une et l'autre edition, est que le titre de la premiere porte: Acta, et celui de la seconde: Historia archiepiscoporum Rotomagensium.

À la suite de ces actes dans le manuscrit de Dom le Tellier, vient une autre histoire encore plus abregée que la précédente, des mêmes Archevêques. Celle-ci est comprise en quarante-six distiques autant que l'on compte d'Archevêques de cette eglise, depuis S. Mallon, sans y comprendre S. Nicaise, jusqu'à Guillaume BonneAme inclusivement ${ }^{23}$.

The first thing to note about this description is that the editors of the Histoire littéraire believed the manuscript used by Martène was almost certainly the Livre noir. Although they acknowledged that it could have been a copy, they maintained that the only major difference between the editions of Mabillon and Martène was that the latter had entitled his Historia (rather than Acta) archiepiscoporum Rotomagensium, which itself recalls the designation in the Livre noir.

The reality is, however, very different. Unlike Mabillon, whose errors are generally slight, the mistakes made by Martène, which are tabulated below, are often significant (table 1). Word forms are not simply mistranscribed with slight alterations in spelling; they are often replaced with entirely different words ${ }^{24}$. Such are their nature, in fact, that Martène's transcriptional "errors" seem more representative of a medieval scribe than an esteemed eighteenth-century erudite. The second noteworthy assertion is that the copy of the Metrical chronicle in the manuscript of Le Tellier, which like that in both the Livre d'ivoire and the Livre noir followed the $A A R$, is said to have had forty-six distiches on all the archbishops of Rouen from Mallonus to William Bona Anima, "sans y comprendre S. Nicaise". This statement makes it unlikely that Martène consulted the Livre noir, for not only does the Metrical chronicle here contain a development on Nicasius that is thirty-two lines in length, but it also concludes with a verse on Eudes Rigaud (1248-1275). He also cannot have consulted the Livre d'ivoire, for he prints a version of the AAR similar to that in the Livre noir (i.e. with the development on Nicasius and the account of the events of 24 August 1073).

22. Jean-Baptiste Le Tellier, professed at Saint-Ouen in 1642, became prior at Beaumont-en-Auge in 1659, was elected grand prior of Saint-Ouen in 1675, and died in this charge on 24 August 1701, aged 75, MARTiMORT, 1978, p. 196.

23. Rivet de la Grange, 1733-, viii, p. 369.

24. Elphège Vacandard mistakenly claimed that Martène's edition contained only three errors, which were of little importance, VACANDARD, 1893, p. 121 n. 2. 
Unfortunately, the identity of Jean Le Tellier's manuscript is unknown. There is no record at the Bibliothèque municipale de Rouen that the Livre noir was ever in his possession, and no list survives cataloguing those manuscripts once owned by him. He was clearly wealthy enough to afford such possessions ${ }^{25}$, however, while Martène's version of the $A A R$ is not the only text edited by him from a manuscript belonging to Le Tellier ${ }^{26}$.

There are also various early modern manuscripts that contain copies of the $A A R$, but since these are based on the versions found in either the Livre d'ivoire or Livre noir, their texts will not form part of the edition given below ${ }^{27}$.

\section{Controversy over authorship}

The existence of two different versions of the AAR has long caused problems for historians. Unaware of the version in the Livre d'ivoire, Jean Mabillon first published the AAR of the Livre noir among his Veterum analectorum. Although there is nothing in the text to indicate an author, he posited that it was written either by Theoderic, monk of Saint-Ouen and author of the Vita metrica Audoeni (BHL no. 754), or Fulbert, of the same monastery, known for his Miracula s. Audoeni (BHL no. $760)^{28}$. Neither Edmond Martène nor Jacques-Paul Migne ${ }^{29}$, who produced the only other full editions of the text, proposed their own candidates, while the extracts printed by Guillaume Bessin, among others, simply repeat either Mabillon's suppositions, or make no comment on the matter ${ }^{30}$. The discovery of the version in the Livre d'ivoire led scholars of the late nineteenth and early twentieth century to reassess the origins of the text, all linking its production to the cathedral ${ }^{31}$. This has led recent scholars, including Marjorie Chibnall, to suggest that the author was perhaps Fulbert, an archdeacon of the cathedral between c. 1047 and c. 1075. He may be the same person as Fulbert the sophista, who was present with Archbishop Maurilius

25. An eighteenth-century manuscript records that upon his death, Le Tellier left 1,200 livres for a great copper eagle to be made, which was erected in the choir of Saint-Ouen on 2 August 1703, Bibl. mun. Rouen, ms Y 114 Omont 1203, p. 27. I am extremely grateful to M. Jean-Marc Colange for bringing this entry to my attention.

26. Martène edited a text concerning the blessing of abbots at Saint-Ouen "ex ms. codice D. le Tellier Rotomagensis s. Audoeni monasterii magni prioris", MARTÈNE, 1788, ii, p. 160-161. This is perhaps BnF, ms nouv. acq. lat. 946, which contains other Saint-Ouen texts edited by Martène, MARTIMORT, 1978, p. 195, 366, 445-446.

27. BnF, ms lat. 5659, fol. 1r-13r (s. xvi, from Livre d'ivoire); BnF, ms lat. 13816, fol. 128r-133v (s. xvii, from Livre noir); BnF, ms nouv. acq. lat. 645 , fol. 1r-48v (s. xvi, from Livre d'ivoire); Arch. dép. Seine-Maritime, $14 \mathrm{H} 151$ (s. xvii, from Livre noir). Misleading catalogue entries also give the impression that two other manuscripts contain copies of the $A A R$, but these are either original works, which use the eleventh-century text as inspiration (BnF, ms lat. 5195, fol. 2r-7r), or an extended version of the Annals of Rouen (BnF, ms lat. 5530).

28. Mabillon, 1675-1685, ii, p. 456. Both of these works are in the Livre noir, Bibl. mun. Rouen, ms Y 41 Omont 1406, fol. 181r-209v, 230r-25or.

29. Martène, 1788, p. 233-248; Migne, $P L$, 1844-1864, clxvii, cols. 273-280.

30. Bessin, 1717, p. 63-64; MANSI, 1757-1798, xx, cols. 395-398; Recueil des historiens..., 1869-1904, xi, p. 70-73; GILES, 1844, i, p. 363-366.

31. Vacandard, 1893, p. 117-118 and 121; Sauvage, 1891, p. 411-412 and 421-424; Duchesne, 19071915, ii, p. 202-203. 
at the monastery of Saint-Évroult on 29 June $1056^{32}$. The primacy of the Livre noir version was championed again recently by Felice Lifshitz ${ }^{33}$, but the matter seems to have finally been settled in favour of the cathedral version ${ }^{34}$.

\section{Author}

Perhaps the most frustrating aspect of the $A A R$ is its total anonymity. As noted above, three candidates (two for the Livre noir and one for the Livre d'ivoire) have been put forward as possible authors, yet none have had their candidacy scrutinised in full until now. Through a palaeographical analysis of the hands themselves, and the manuscripts in which the AAR appears, some clarity is possible with regards to the identity of at least one of the authors. Moreover, in pursuing this investigation, previously unidentified quotations and allusions have been discovered, which themselves provide a better sense of the sources used by those responsible for the $A A R$, their respective levels of learning, and their tastes. For matters of convenience and clarity each version shall be examined individually, beginning with that in the Livre d'ivoire.

Only a handful of manuscripts produced or owned by the cathedral during the eleventh century survive. These include the benedictional of an archbishop Robert, a missal, and a copy of Gregory the Great's Liber pastoralis curae ${ }^{35}$. None contain the hands of the AAR in the Livre d'ivoire, whose distinctive capital "G" and $\mathrm{z}$-shaped "r" serve as useful points of comparison (figs. 1 and 3 ) $^{36}$. The hands are also not repeated in the Livre d'ivoire itself, although some have argued otherwise ${ }^{37}$, nor are they found in the surviving charters produced by the cathedral scriptorium during the eleventh and early twelfth centuries ${ }^{38}$. The script from the second page onwards, while quite untidy, is uniform throughout, except for the last word (disciplinis), which is in a different hand. Felice Lifshitz believed this was evidence that the cathedral version was a scrappy copy of that in Livre

32. $O V$, iii, p. xxvi-xxvii. Others who support Fulbert as author include PotTHAst, 1896, p. 476. For Fulbert at Saint-Évroult see OV, ii, p. 66; for details of his career, see SpEAR, 2006, p. 206-207.

33. LifshitZ, 1990, p. 337-347.

34. Violette, 1997a, p. 113-129; Violette, 1997b, p. 343-365; ViOlette, 2003, p. 57-67; Violette, 1994, ii, p. 131-271; Diard and Gazeau, 2003, p. 210-218.

35. Bibl. mun. Rouen, ms Y 7 Omont 369, Bibl. mun. Rouen, ms A 260 Omont 500 and Bibl. mun. Rouen, ms A 566 Omont 275.

36. A number of later additions in the benedictional, which is Anglo-Saxon in origin, are written in hands that share certain other characteristics with those of the $A A R$, Bibl. mun. Rouen, ms Y 7 Omont 369, fol. 1v-3r, 81v-82v, 177r, 188r-19or, $191 \mathrm{v}$.

37. There are five other pieces within the Livre d'ivoire written in hands of the period, including a vita of Gildardus (p. 42-56); an account of the deposition of the relics of St. Romanus (p. 62-85); the office of St. Romanus (p. 86-91); a vita of St. Ouen (p. 92-128) and one of St. Ansbert (p. 129164). All subsequent material dates from between the fourteenth and eighteenth centuries. Lifshitz believed that the vita of Gildardus up to p. 46 was in the same hand as the AAR (LifSHITZ, 1990, p. 341), but while it shares some similarities with the hands of the $A A R$, I am not convinced.

38. Arch. dép. Seine-Maritime, G 1846, G 4014, G 8739, G 8740 and 14 H 189 (lower half). The hand of the third of these documents does contain some features similar to the hands of the $A A R$, but enough are different to suggest a different scribe. 
noir, and that the word had been inserted later. But a closer examination of the parchment reveals that (perhaps badly faded) it was simply scratched away and rewritten more clearly by a later scribe, who may also have been responsible for inserting into the Metrical chronicle the verse to St. Nicasius, which is written in a hand of the late twelfth or early thirteenth century (fig. 4).

Unfortunately, as Jean-Michel Bouvris has noted somewhat wryly, this remains a period in which the capitulary school of Rouen is "riche en œuvres mais pauvre en mentions d'hommes" ${ }^{39}$. Even with David Spear's prosopographical survey of the dignitaries of the chapter of Rouen to hand, one struggles to find a candidate even vaguely suitable to fulfil the role of author ${ }^{40}$. Irrespective of his identity, the scribe responsible for the $A A R$ in the Livre d'ivoire was clearly a highly capable individual. In writing the $A A R$ he not only processed and collated a great deal of existing information, but also created his own when necessary. While there is nothing extraordinary about the Latin he employs, the poem in dactylic hexameters dedicated to Mallonus has the correct versification (except the last verse), and is of a relatively sophisticated nature that at one time acted as proof that the monk Theoderic of Saint-Ouen, a skilled poet, had written the "original" version of the AAR in the Livre noir ${ }^{41}$. Its similarity in style to the Metrical chronicle of the archbishops has already been commented on elsewhere ${ }^{42}$. The cathedral author had access to, and made good use of, a wide range of sources, including the vitae of SS. Romanus, Ouen, Ansbertus, Gildardus and Hugh (either the Jumièges or Saint-Wandrille version), as well as the Vita sancti Medardi by Venantius Fortunatus, the Miracula sancti Benedicti by Adrevaldus of Fleury, Gregory of Tours' Decem libri historiarum, a number of charters and two papal letters. He was also apparently familiar with the work of St. John Chrysostom, since he appears to have lifted text, which he amends slightly, from a Latin translation of the saint's sermon on the sale of Joseph by his brothers ${ }^{43}$. The cathedral scribe may, moreover, have used a copy of the Annales regni Francorum, for his reference to the consecration of Pippin III (741-768) by Pope Stephen (752-757) must originate from a written source ${ }^{44}$, while certain other assertions suggest he may have seen a copy of Dudo of Saint-Quentin's De moribus et actis primorum Normanniae ducum ${ }^{45}$. Of course, none of this brings us any closer to his exact identity, and until further evidence surfaces to prove otherwise, the most likely candidate remains Fulbert the archdeacon.

39. BOUVRIS, 1986, p. 97.

40. Spear, 2006, p. 195-268.

41. Rivet de la Grange, 1733-, viii, 367.

42. Violette, 1997 b, p. 357.

43. Compare the author's "sed quia vita iustorum est detrimentum pessimorum" with "sic bonorum vita detrimentum est pessimorum" of John Chrysostom, "De Joseph, ubi a fratribus venditur", in Divi Ioannis Chrysostomi..., p. 427.

44. The consecration took place in 754, Kurze, 1895, p. 12. The Annals of Rouen note Pippin's ascension to the throne under the year 752 (Chronicon Rotomagense..., p. 365), but make no mention of the role of the pope, while it is unlikely that such information would have formed part of the collective memory of the community at Rouen.

45. E.g. that Rollo was baptised by Archbishop Franco, Dudo of Saint-Quentin, De moribus..., p. 170. 
The situation is much better for the AAR in the Livre noir. The hand that appears on folios $1 \mathrm{r}-8 \mathrm{v}$ (fig. 5 ) is so distinctive that it can be easily identified from others of the codex, while the script on folios 9 r-11r (figs. 6 and 7), previously thought to be the same as that on folios $1 \mathrm{r}-8 \mathrm{v}^{46}$, can now be shown as the work of two completely different scribes. We can also now definitively identify the original scribe as Theoderic, a monk at Saint-Ouen during the reign of Abbot Nicholas.

The script that appears on folios $1 \mathrm{r}-8 \mathrm{v}$ of the Livre noir has two distinctive letters: the lowercase " $\mathrm{e}$ " and the uppercase " $\mathrm{N}$ ". Unlike the other hands predominant in the Livre noir (including those on folios 9r-11r), the lowercase " $\mathrm{e}$ " that appears on folios $1 \mathrm{r}-8 \mathrm{v}$ is broad in style, and the line which forms the bottom of the upper compartment is flat, running parallel with the ruled line (fig. 8). In other hands in the Livre noir, including those on folios 9r-11r, the line which forms the bottom of the top compartment of the letter " $\mathrm{e}$ " is at an oblique angle to the ruled line, making the compartment smaller and the letter as a whole more angular (fig. 9). Similarly, the uppercase "N" of the first eight folios is always formed by three straight pen strokes, with the bridge between the two ascenders always running obliquely from just above the halfway point on the left vertical line, to just below the same point on the right (fig. 8). In contrast, the capital "N"s which appear elsewhere in the Livre noir, including folios 9r-10v, take two forms: they are either straight lined with the bridge running obliquely from the top of the left ascender to the bottom of the right, or in a looped form (figs. 9 and 10). The appearance of the latter on folio $9 \mathrm{v}-\mathrm{a}$ form which is never used in the 139 folia of the codex where the hand of folios $1 \mathrm{r}-8 \mathrm{v}$ appears-clearly demonstrates that it was written by a different scribe. There is also a dramatic increase in the use of abbreviations on folios $9 \mathrm{r}-10 \mathrm{v}$, especially suspension marks ${ }^{47}$, while the line amounts decrease from twenty-eight per folio on folios $1 \mathrm{r}-8 \mathrm{v}$ to twenty-seven on folios $9 \mathrm{r}-1 \mathrm{ov}$. All this points to a single conclusion: a different scribe was responsible for these folia. Similarly, the hand on folio 11r can be considered distinct from that on folios $1 \mathrm{r}-8 \mathrm{v}$ and $9 \mathrm{r}-1 \mathrm{ov}$ for it is calligraphically very different, as figure 7 clearly demonstrates.

Unfortunately, the hand on folio 11r does not occur again in the Livre noir, while the process of identifying the other two is challenging. Jean-François Pommeraye, Jean Mabillon and the editors of the Histoire littéraire de la France identified four different monks whom they claimed had produced works in the Livre noir. These include Theoderic, who they alleged composed the $A A R$, the Metrical chronicle and the metrical vita of St. Ouen; the dean and monk John, who allegedly wrote four sermons on SS. Nicasius and Ouen, two lives of St. Nicholas and an amended version of Theoderic's metrical vita; Ambrose, who it is

46. For Felice Lifshitz, the AAR and the Metrical chronicle in the Livre noir "are written by the same hand and form a codicological unit" (Lifshitz, 1990, p. 339), while Louis Violette argued that the hand is the same throughout and simply "devient... plus cursive au cours du texte", ViOLETTE, 1997a, p. 114 .

47. On folios $1 \mathrm{r}-8 \mathrm{v}$ there are a total of 488 suspension marks, which is an average of 30.5 per folio, or just over 1 per line. In contrast, there are 280 suspension marks on folios 9 r-10v, which is an average of 70 per folio, or almost 3 per line. 
claimed wrote two passions, one in prose and one in verse, on St. Agnes; and Fulbert, whom it is held composed the Miracula s. Audoeni ${ }^{48}$. Regrettably, these identifications are confused and highly misleading. The Ambrose acknowledged by the Histoire littéraire as a monk of Saint-Ouen is actually St. Ambrose, bishop of Milan from 374 to $397^{49}$. The passion in prose dedicated to St. Agnes in the Livre noir (fol. 61v-69v) is merely a corrupted version of his Vita s. Agnetis (BHL no. 156), while the metrical version (fol. 69v-83r) is the work of an unidentified Saint-Ouen monk ${ }^{50}$. Furthermore, while there was a monk of Saint-Ouen called John active in the early twelfth century ${ }^{51}$, he did not compose the prose vita of St. Nicholas (fol. 250r-278v) as is claimed ${ }^{52}$. This was instead the work of John the dean of St. Januarius, who lived in Italy in the early tenth century ${ }^{53}$, and who also wrote the Historia translationis of St. Severinus of Noricum and the acta of St. Januarius and his companions ${ }^{54}$. There is also nothing to link the metrical vita of St. Nicholas (fol. 305r-331v) in the Livre noir with the Saint-Ouen monk John, while of the four sermons attributed to him, which it is claimed Edmond Martène edited from the Livre noir ${ }^{55}$, only two are found complete in the codex, while none make any reference to John ${ }^{56}$. The other two (the translations of St. Ouen) are fragmentary in form ${ }^{57}$, and are only found in their entirety in a thirteenth-century manuscript belonging to the abbey ${ }^{58}$. Moreover, it has recently been argued that both the translations of St. Ouen (fol. 211r-216r) were most likely composed around the year 1000, and therefore anyone producing the texts in the late eleventh century was only doing so as a copyist ${ }^{59}$. As for the claim that John produced an amended version of Theoderic's metrical vita of

48. Pommeraye, 1662, p. 339; Rivet de la Grange, 1733-, viii, p. 364-37o; x, p. 262-264; Mabillon, 1675-1685, ii, p. 456.

49. The Histoire littéraire de la France says the following on Ambrose, an alleged monk of Saint-Ouen: "Il ne faut point séparer du moine Jean, Ambroise, religieux de la même abbaye [i.e. Saint-Ouen], qui employa sa plume a célébrer en prose et en vers l'illustre sainte Agnès, vierge et martyre”, Rivet De LA Grange, 1733-, x, p. 264.

50. Both works are written in the hand of folios $9 \mathrm{r}-10 \mathrm{v}$. The foliation also skips from $69 \mathrm{v}$ to 8 or.

51. John is perhaps most famous as the recorder of the canons of the Council of Reims (1119), OV, vi, p. 274.

52. “Jean n'avoit pas encore vingt ans, lorsqu'il composa en prose et en vers la vie de saint Nicolas", Rivet de la Grange, 1733-, x, p. 263.

53. AASS, Feb. 9, II, p. 313.

54. It seems the editors of the Histoire litterraire misinterpreted the following sentence in the prologue of the vita of St. Nicholas: "Quod ego Ioannes indignus diaconus servus sancti Ianuarii multum devitans, tibi me saepius roganti, frater Athanasi, rusticitatis obstaculum opponebam”, Bibl. mun. Rouen, ms Y 44 Omont 1406, fol. 250v. For John's other works, see AASS, Jan. I, Ad VIII Ianuarii, p. 1098-1103; Sep. VI, Ad XIX Septembris, p. 873-884.

55. Rivet de la Grange, 1733-, x, p. 263. Martène's edition was republished in Migne, PL, 18441864, clxii, cols. 1153-117o.

56. That is the Translatio B. Nicasii martyris (fol. $32 \mathrm{v}-36 \mathrm{r}$ ) and the Sermo in festivitate sanctorum (fol. 87r-9ov).

57. The first and last folios of the Translatio prima are missing (fol. $214 \mathrm{r}-216 \mathrm{v}$ ), while the last folio of Translatio secunda is also absent (fol. 211r-213v).

58. Bibl. mun. Rouen, ms U 64 Omont 1411, fol. 95r-98v.

59. Arnoux, 1999, p. 30, 35-36, 38; Trân-Duc, 2006 p. 526. 
St. Ouen ${ }^{60}$, which seems to be a reference to the compendium of the vita found in the Livre noir ${ }^{61}$, this text also contains no mention of John.

Fortunately, the association of Theoderic with his works in the Livre noir rests on slightly firmer ground. The distinctive features of the script on folios $1 \mathrm{r}-8 \mathrm{v}$ of the $A A R$ noted above are easy to find elsewhere, and of the eight times that the hand appears in the codex, one is a copy of Theoderic's metrical vita of St. Ouen ${ }^{62}$. This is considered autograph ${ }^{63}$, and also contains a statement that links Theoderic to the abbey in the time of Abbot Nicholas ${ }^{64}$. Since it is written in the same hand as the $A A R$, it seems that Theoderic was most probably the scribe responsible for the amended copy of this work in the Livre noir. As for the Miracula s. Audoeni (fol. 181r-209r) associated with the monk Fulbert, it not only contains no mention of his name in the text, but it is also in the same hand as folios $1 \mathrm{r}-8 \mathrm{v}$ of the $A A R$, which suggests that it was in fact produced by Theoderic.

The reason behind the different hands in the $A A R$ of the Livre noir remains unclear. The palaeographical consistency of the other works in the codex is noteworthy, while Theoderic himself was clearly capable of producing lengthy and sophisticated works in a remarkably regular script. The longest is written over forty-six folia ${ }^{65}$, and is itself evidence that the script on folios 9r-11r cannot be, as Louis Violette suggested, simply a more cursive version of his hand ${ }^{66}$. One explanation for the change in hands might be that Theoderic had died, for a previously unidentified quote in the $A A R$, which is taken from the second book of the Maccabees, suggests he may have been an old man by the early $1090 \mathrm{~s}^{67}$. Once popular exemplars for both the laity and clergy, by the end of the eleventh century the Maccabees were seen as increasingly outdated models ${ }^{68}$. The fact that Theoderic neither draws attention to the verse, nor quotes it verbatim, could suggest that, while keen to quote from one of his favourite pieces of Scripture, he recognised the need to do so subtly. But if he did pass away, he certainly chose to do so at a very convenient moment, for he ceased to write exactly at the end of folio $8 \mathrm{v}$. A more

60. Rivet de la Grange, 1733-, x, p. 263.

61. Bibl. mun. Rouen, ms Y 41 Omont 1406, fol. 223r-229r.

62. Excluding Theoderic's vita of St. Ouen the hand can also be found at fol. 17r-23v (a passion of St. Nicasius); 91r-109r (a vita of St. Ouen); 124r-180r (a vita of St. Ouen); 181r-209r (miracula of St. Ouen); 250r-278v (a vita of St. Nicholas); 279r-289r (a vita of St. Vulgani) and 331v-end (translation of St. Vulgani).

63. Rivet De La Grange, 1733-, viii, p. 366.

64. Theoderic's vita begins with the assertion that Abbot Nicholas asked him to compose a life of the saint: "Patri sincero, tranquilla pace sereno | Patri proelaro virtutum flore beato | Abbati sancto Theodericus Nicolao | Commissi curam gregis, ut dat virga figuram | Qua trahit imbelles, procul expellendo rebelles $\mid$ En quae mandasti: vel quae scribenda rogasti $\mid$ De sancta sancti vita, meritisque beati | Praesulis Audoeni; proprio pro posse peregi", Bibl. mun. Rouen, ms Y 41 Omont 1406, fol. 23 or.

65. Bibl. mun. Rouen, ms Y 41 Omont 1406, fol. $124 \mathrm{r}-18 \mathrm{ov}$. The foliation skips from $169 \mathrm{v}$ to $18 \mathrm{or}$, hence the reduction in the number of folios by ten.

66. Violette, 1997a, p. 114.

67. Theoderic writes "Non enim inhabitantes propter locum, sed propter inhabitantes locum Dominus elegit". The actual passage runs "verum non propter locum gentem sed propter gentem locum Dominus elegit”, Maccabees II 5:19.

68. For discussion, see Dunbabin, 1985, p. 31-41. 
likely explanation is that the last three folia of the $A A R$ were at some time damaged on two separate occasions and then replaced: once in the period soon after initial composition, and then again in the late twelfth or early thirteenth century (the hand of folio 11r). In fact, the Livre noir might have been subjected to greater upheavals than previously thought. None of its pages have medieval foliation (all are poorly numbered in an early modern hand using Arabic numerals), while in at least one place a page has been torn out ${ }^{69}$. The last folio of the Translatio secunda of St. Ouen on folios 211r-213v is also missing, as are the first and last of the Translatio prima on folios $214 \mathrm{r}-216 \mathrm{v}^{70}$. The fact that none of the folia between $9 \mathrm{r}$ and $11 \mathrm{r}$ contain the illuminated initials so obvious in the preceding pages may suggest they were replaced in a hurry ${ }^{71}$. The lack of medieval foliation could indicate that the codex is perhaps not bound in the order as originally envisaged, and if folia were torn, and others missing, there is every chance some were also damaged.

Having identified Theoderic as the scribe responsible for the AAR in the Livre noir, it is unfortunate that we know nothing of the man himself ${ }^{72}$. His name, which is German in origin ${ }^{73}$, is not common in the duchy, and it is possible he came from outside Normandy, perhaps from Burgund ${ }^{74}$. He was clearly fairly well read, since his version of the $A A R$ includes quotations, often slightly amended, from the works of Gregory the Great ${ }^{75}$, St. Augustine (see below), and perhaps even the Venerable Bede ${ }^{76}$. There is, however, a certain diffidence to Theoderic's learning, for the allusions he makes are seldom referenced explicitly or quoted verbatim. Perhaps the best example of this practice is the reference made to a passage of De civitate Dei, which runs as follows: Dicto nil subripit quod refragetur, tantum ratio ipsa a toto pendens suffragatur ${ }^{77}$. Of course, the decision to quote De civitate Dei, one of the most popular texts for medieval authors to reference, is hardly surprising. There is nothing noteworthy about

69. This is between fol. 9ov-91r. Four coloured initials are visible on the remaining fragment and appear as follows: xvi Q (beginning of a line of text) xvii D xviii Q xix D.

70. The complete text can be found in Bibl. mun. Rouen, ms U 64 Omont 1411, fol. 97r-98v.

71. A space has been left for an initial " $S$ " on folio 11r, but it was never filled in. An early modern hand provides the letter (see fig. 7).

72. The longest, but highly inaccurate, account of his life and works is RIVET DE LA GRANGE, 1733-, viii, p. 364-37o. A shorter biography can also be found in Pommeraye, 1662, p. 339.

73. MORLET, 1965-1987, i, p. 69.

74. One of the few prominent individuals called Theoderic operating in Normandy during the ducal period came from Dijon, Gazeau, 2007, ii, p. 30, 148, 204. It is possible our Theoderic shared similar connections.

75. Compare Theoderic's “... in fluxum usque superbię ipso potentie fastigio lenocinante corrumpere” with "... in fluxum superbiae ipso potentiae fastigio lenocinante corrumpitur" in Gregory the Great's Liber pastoralis curae, Migne, PL, 1844-1864, lxxvi, col. 375.

76. The phrase "tales non pastores sed crudeles exactores" may be an amended version of "tales non pastores, sed mercenarios", which appears in one of Bede's Homilies, Migne, PL, 1844-1864, xciv, col. 217.

77. This paraphrases the following passage from Augustine’s work: “...; deinde, quia testimonium quod profertur, de contextione totius Psalmi debet habere suffragium ut certe nihil sit quod ei refragetur, si non omnia suffragantur,...", Augustine of Hippo, De civitate Dei contra Paganos, Liber XVII, caput XV, in Migne, $P L, 1844-1864$, xli, col. 548. 
the composition of Theoderic's rephrasing, although it is taken from the section of De civitate Dei on the Psalms ${ }^{78}$. Given that Theoderic's other major work is a verse-based vita, it is possible the Psalms held a special attraction for him. This idea is given credence by the appearance in the $A A R$ of text lifted from this part of the Bible ${ }^{79}$, which, on occasion, St. Augustine quoted very similarly ${ }^{80}$. Unfortunately, there is no surviving Psalter from Saint-Ouen in which we can find his hand, while he appears to have had no part in producing the works he references. The only surviving copy of De civitate Dei produced at Saint-Ouen dates from the mid-twelfth century ${ }^{81}$, while the only surviving eleventh-century Bible in Saint-Ouen's possession that includes the books of the Maccabees was produced at the abbey of Lyre ${ }^{82}$. With over fifty manuscripts from the eleventh and twelfth centuries belonging to the abbey of Saint-Ouen in the collection of the Bibliothèque municipale de Rouen alone, a complete examination of every codex in search of Theoderic's distinctive hand was beyond the scope of this article. Nevertheless, the above has hopefully enlightened some of the hazier aspects of the authorship of the AAR in the Livre noir.

\section{Historical value}

Louis Violette has already established the important part played by the $A A R$ in the program of clerical reform pursued by the eleventh-century archbishops of Rouen, and its place within the rivalry that existed between the cathedral of Rouen and the abbey of Saint-Ouen ${ }^{83}$. Consequently, the value of the AAR considered here concerns its factual efficacy. The text is, of course, partly panegyrical and hagiological, which means that its authors were not necessarily concerned with historical accuracy. It nevertheless contains some unique details concerning the eleventh-century archbishops, as well as some interesting ambiguities that, although they are undoubtedly a consequence of the $A A R$ 's eulogistic nature, have hitherto never been examined in detail.

78. I am indebted to Roger Green and Karla Pollmann, who patiently answered my queries concerning this allusion (pers. comm.).

79. Theoderic reminds the reader to "strive continuously to serve the Lord in fear, and to rejoice, but with trembling" (studendum continue Domino servire in timore, et exultare ei, sed cum tremore), which echoes Psalms 2:11, "Serve the Lord with fear, and rejoice with trembling" (servite Domino in timore et exultate ei in tremore).

80. Towards the end of the AAR, Theoderic asks the reader to contemplate "the judgements of God, which are like the great deep" (iudicia Domini que velut abissus multa sunt). This echoes Psalms 35:7, which is rendered in the modern Vulgate as "iustitia tua sicut montes Dei iudicia tua abyssus multa homines et iumenta salvabis Domine". Interestingly, St. Augustine quotes from the verse of this psalm in his letter to Honoratus, which he entitled "De Gratia Novi Testamenti Liber", and uses phrasing similar to Theoderic: "Et iterum: Iudicia tua velut abyssus multa" and "...continuo in eodem psalmo ... subiunxit, Judicia tua velut abyssus multa”, MIgne, PL, 1844-1864, xxxiii, cols. 565,569 .

81. Bibl. mun. Rouen, ms A 108 Omont 482 (the quote rephrased by Theoderic is on fol. 117r).

82. Bibl. mun. Rouen, $\mathrm{ms} \mathrm{A}_{3}$ Omont 3. It was transferred to Rouen after the French Revolution.

83. For bibliographical details see n. 34 . 
This is particularly true of the entry concerning Archbishop Maurilius. Despite containing numerous details of the archbishop's life before he came to Rouen, and from his later career, the passage is almost completely devoid of chronological information. When chronological reference points are given they are often indistinct. For example, the $A A R$ states that Duke William deposed Maurilius' predecessor Mauger at Lisieux "with the authority of Pope Leo and in the presence of the papal legate Ermenfrid, bishop of Sion". As Leo IX died on 19 April 1054, it was often assumed that the deposition council was held in the same year ${ }^{84}$. It is likely, however, that Ermenfrid of Sion did not become legate until $1055^{85}$, while various Norman annals place the council in this same year ${ }^{86}$. H.E.J. Cowdrey has argued that perhaps the confusion in the $A A R$ suggests the chain of events that resulted in the deposition of Mauger may have begun, at least, with a request by Duke William to Pope Leo ${ }^{87}$. This does not explain why, however, in a work that was obviously designed to honour Maurilius to a certain extent, and was perhaps written by Fulbert, an archdeacon of the cathedral who worked intimately with the archbishop, such uncertainties should exist.

The other ambiguities concern Maurilius' conciliar legacy. Those councils held by the archbishop, the years in which they were convened, the location of the meeting, the business under discussion, and the source for the information can be easily tabulated (table 2). Of these five, three are difficult to assign a date: those of $1055,1055 \times 1063$ and 1061. The easiest to reject is that of 1061, which Guillaume Bessin claimed was held at Caen ${ }^{88}$. Anne Brinkworth demonstrated that his "canons" are little more than a Latin translation of events described by Gabriel du Moulin and Charles de Bourgeville, who mistakenly attributed information relating to the Truce of God meeting convened at Caen in October 1047 to a separate meeting fourteen years later ${ }^{89}$. There was a synod convened in 1061 at which Maurilius was present, but it was held at Rouen, and concerned the election of Osbern, prior of Cormeilles, as abbot of Saint-Évroult ${ }^{90}$. The other two councils, those of 1055 and $1055 \times 1063$, are more difficult to identify. Not only is it hard to decide whether one should place the date for the council in either of these two timeframes, but the possibility also exists that neither of these councils occurred and both are in fact misplaced references for a council that took

84. For arguments in favour of 1054, see Douglas, 1964, p. 69, n. 3.

85. This is the opinion of BoÜARD, 1959b, i, p. 89. The most recent biographer of Ermenfrid is not convinced, however, CowDREY, 1969, p. 226 n. 1.

86. Chronicon Rotomagense..., p. 366; Annalis Cadomensis..., in GILES, 1845, p. 165; Annales Uticenses, in Le Prévost, 1838-1855, v, p. 157; Annales de Jumièges..., in LAPORTE, 1954, p. 56; The Hague, Koninklijke Bibliotheek, ms 128 E 14, fol. 1or (annals of Saint-Wandrille). I am extremely grateful to Alison Alexander for supplying me with a photocopy of the last of these.

87. COWDREY, 1969, p. 227 n. 1.

88. BESSIN, 1717 , p. 48

89. Brinkworth, 1966, p. 337-338. Raymonde Foreville, however, held that the council took place, despite her admission of an obvious corruption in the first canon, Foreville, 1976, p. 22, 26 and n. 18. David Bates followed these conclusions, BATES, 1982, p. 199.

90. OV , ii, p. 92. This synod was not included among those studied by Raymonde Foreville. 
place on 1 October 1063. The cause of all this uncertainty is the $A A R$ itself, which contains the following passage:

Hic [Maurilius] æcclesiam a Rotberto archiepiscopo inceptam complevit, et astante Guillelmo Normannorum duce, postea Anglorum rege cum omnibus suffraganeis suis, concilium in Rotomagensi æcclesia de castitate conservanda, et cęteris sanctorum patrum institutionibus pastorum incuria neglegenter postpositis viriliter restituendis religiose cęlebravit. Postea perfecta æcclesia dedicavit eam astante Guillelmo Normanorum duce anno.MLXIII. Dominicę Incarnationis, regnante Henrico nobilissimo rege Francorum, astantibus etiam cumprovintialibus episcopis, scilicet Odone Baiocensi, Iohanne Abrincensi, Hugone Luxoviensi, Guillelmo Ebroacensi, Ivone Sagiensi, Gaufrido Constantiniensi, cęterisque venerabilibus abbatibus, presidente etiam sedi apostolicę papa Victore secundo.

Two problems arise from this. First, the statement that Henry was king of France and Victor was pope is chronologically impossible, since Victor II died in 1057 and Henry I in 1060. The statement that the dedication took place in 1063 appears correct, however, as various Norman annals corroborate this date ${ }^{91}$. The second problem arises when the assumption is made that the date of 1063 attributed to the dedication is also intended to apply to the council mentioned just before. Such an assumption is understandable, since the author, after describing the convening of the council, begins the sentence that goes on to describe the consecration with the word "afterwards" (postea). The key to resolving these chronological difficulties depends on when Maurilius promulgated his elaborate eucharistic confession of faith, which was issued "against the immoral Berengar [of Tours], and the voices of his followers" ${ }^{92}$. Previously assigned to either 1055 or $1063^{93}$, Robert Somerville has recently demonstrated that Maurilius must have issued the confession during the earlier of these years ${ }^{94}$. Consequently, the council in 1055 did not deal with the issues of celibacy, and is therefore not the council mentioned by the $A A R$, while the council held on 1 October 1063 did not deal with the Berengar controversy.

Of course, there is still the possibility that there was a separate council that was held neither in 1055 nor on 1 October 1063, but sometime between 1055 and 1063. However, even if the $A A R$ is taken at face value, then the possibility of a separate council held between 1055 and 1063 appears unlikely. Indeed, it is important to note the one element that remains constant in the AAR's narration of both the council and the dedication: the completed cathedral. It could of course be suggested that the cathedral was completed before 1063 and that a council was held in 1062 or early 1063, and that all those involved were summoned back to Rouen

91. Chronicon Rotomagense..., p. 366; Annales Uticenses..., p. 157; Annales de Jumièges..., p. 56.

92. “... contra spurcissimas Berengarii eiusque successorum voces”, Recueil des historiens..., 1869-1904, xi, p. 529.

93. For 1055, see Recueil des historiens..., 1869-1904, xi, p. 529; for 1063, MignE, PL, 1844-1864, cxliii, col. 1383 .

94. Somerville, 1972 , p. 57-58, n. 11. 
for the dedication in October. However, although an insertion into an eleventhcentury benedictional assumed that two provincial councils were to be held each year ${ }^{95}$, with some actually claiming this right ${ }^{96}$, such organised regularity does not become apparent in Normandy until after 1066, and even then it still fails to meet the standards set ${ }^{97}$. It would seem strange, therefore, not to use such a solemn occasion as a consecration to hold a council ${ }^{98}$. We certainly see the combination of the two later in the duchy's history, when a synod was held following the dedication of the abbey of La Trinite de Caen on 18 June $1066^{99}$. The date of the consecration is also important. We know that when Geoffrey de Montbray, bishop of Coutances, came to dedicate his cathedral seven years earlier he had waited until 8 December, the feast day of the conception of the Blessed Virgin Mary, a festival of some importance in the city ${ }^{100}$. Similarly, when Odo, bishop of Bayeux, dedicated his cathedral on 14 July 1077, the day not only commemorated the anniversary of the translation of the relics of SS. Exupère and Loup (former bishops of Bayeux) to the cathedral, but also their feast day ${ }^{101}$. It appears Maurilius did the same: 1 October was the feast day of St. Vedast of Arras, a saint whose cult was especially important at Rouen ${ }^{102}$. It is hard to imagine a more opportune occasion to hold a council that discussed important aspects of the restoration of the Norman Church, than at the dedication of the duchy's primary cathedral on the feast day of a man famed for restoring the faith of his people, and the churches in which they worshipped ${ }^{103}$.

While such chronological irregularities cause numerous problems for the historian, there are a number of interesting details within the AAR that compensate for these lapses. Most notable of these is the pontifical letter from Pope Alexander II to Archbishop John. Although this must have once constituted part of the cathedral archives, it is no longer to be found. Details in the letter allow us to confirm the version of events preserved by the Vita Lanfranci and Orderic Vitalis, both of which state that Lanfranc was dispatched to Rome to secure papal approval for the translation of John from Avranches to Rouen, and was successful ${ }^{104}$. The cathedral author of the $A A R$ also included extracts from another papal letter, this time sent from Pope Innocent I (401-417) to Bishop Victricius (386-c. 404), the full text of which can be found elsewhere ${ }^{105}$. The $A A R$ also has some diplomatic value. The text confirms that a charter of Charles the Bald (843879) granted to Bishop Riculfus in 875 , which mentions the benefice of Cramoisy

95. Wilson, 1903, p. 154.

96. "Etiam si episcopus defuerit, abbas cum duobus de canonicis bis in anno debet esse ad synodum...", Keats-Rohan, 2006, Appendix 2, $\mathrm{n}^{\circ} .5$.

97. See Foreville, 1976, p. 22 for the councils post-1066.

98. Such a suggestion is made, but not explored, in BRINKWORTH, 1966, p. 336.

99. Fauroux, 1961, $\mathrm{n}^{\circ}$. 229. For the date of the dedication, see Fauroux, 1961, $\mathrm{n}^{\circ} .231$.

100. LELEGARD, 1995, p. 296.

101. BATES, 1970, p. 47.

102. GRoteFEND, 1991, p. 105.

103. For his vitae, see AASS, 6 Feb., I, p. $792-794$ and Migne, $P L, 1844-1864$, ci, cols. 663-681.

104. $O V$, ii, p. 200; Gibson, 1993, p. 682.

105. For the full text, see Migne, PL, 1844-1864, xx, cols. 469-481; lvi, cols. 519-527. 
(Cramisiacum) donated by Bishop Rainfredus (748), was to be found among the cathedral records in the eleventh century. The author does not appear to have consulted it very closely, however, for he incorrectly states that Cramoisy lies in the Vexin, whereas the charter states (correctly) that it is in the Beauvaisis ${ }^{106}$. Moreover, the Saint-Ouen version of the $A A R$ seems to confirm the details of a donation made by Archbishop John while he was still bishop of Avranches. In 1066, he donated parts of his honour of Vièvre to the cathedral of Avranches on the condition that as long as he lived they should remain in his power ${ }^{107}$. This condition was apparently observed as John, according to the AAR in the Livre noir, retired to Saint-Philbert (within Vièvre) two months before his death.

The additions to the AAR made by Theoderic are also not without value, although he is not always a reliable authority. He incorrectly identifies Robert, abbot of Sées, as Richard, and states that Archbishop John became paralysed three years after the tumult and was ill for three more before dying. John, however, suffered his attack of apoplexy in July 1077, and died two years later ${ }^{108}$. Theoderic does, however, provide us with interesting details regarding John's capacity after his stroke of July 1077, about which there is some confusion. According to Orderic Vitalis, Gilbert Maminot was consecrated the new bishop of Lisieux sometime between 25 July and 23 October 1077 in John's presence, although the actual service was performed by Michael, bishop of Avranches (1068-1094), due to the archbishop's incapacity ${ }^{109}$. The editors of Gallia Christiana attributed the consecration of the church of Saint-Amand de Rouen on 29 September 1078 to John, but according to Orderic the attack of apoplexy caused the archbishop to lose the power of speech, and such a statement must therefore be regarded with scepticism ${ }^{110}$. Similarly, one can now moderate Orderic's assertion regarding the consecration of Bec, which he stated was carried out by John and his bishops ${ }^{111}$. This event actually took place after John's attack of apoplexy, and was performed by the abbey's former prior, Lanfranc. John was apparently unable to attend, even as an observer, as he is not included in the list of those present given in the Chronicle of Bec ${ }^{112}$. The beginning of the end of his archiepiscopate is typically seen in April 1078, when Pope Gregory VII wrote to the English king stating that he had heard that the see of Rouen was without a pastor through infirmity, and that he was sending his legate Hubert to investigate. Should Hubert find John unable to fulfil his duties another archbishop was to be

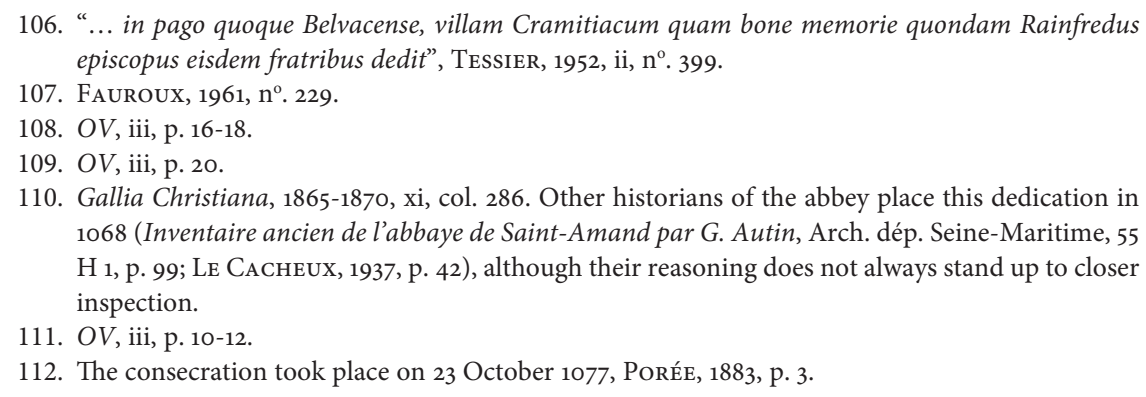


elected in his place ${ }^{113}$. Although no record of an assembly to force the resignation of John survives, it has been argued that it was likely one took place ${ }^{114}$.

Theoderic, however, claims that John, having begun to recover from his illness, attended the feast day Mass of St. Ouen in August $1078^{115}$. Gilbert, bishop of Évreux (1071-1112), officiated at the ceremony, and the incapacitated archbishop, unable to control his bladder, wet himself during the reading of the Gospel, soaking his clothes and leaving a puddle on the floor ${ }^{116}$. Clearly he was in a poor state of health, but despite being so severely incapacitated John was, according to Theoderic, still archbishop, almost four months after the date usually assigned to his deposition council ${ }^{117}$. It is even possible that he clung to his position at least until early 1079. At Lillebonne in this year Ralph the chamberlain conceded and confirmed the grant made by Fulk de Mirville of the church, six acres and all the tithe of Mirville to the abbey of Jumièges ${ }^{118}$, to which John, as archbishop of Rouen, consented. This donation formed part of a pancarte of this same abbey drawn up sometime between 1079 and c. $1087^{119}$. The absence of signa on the original led David Bates to suggest that it was never presented for confirmation, but it is likely that the details of the donation by Ralph the chamberlain came from a pre-existing document, which is now lost, and that, at least in the mind of this document's scribe, John was still to be considered archbishop. It is only with the consecration of Anselm as abbot of Bec on 22 February 1079 by Gilbert of Évreux that John seems to have left his office permanently, for the Libertate Beccensis monasterii states that the bishop of Évreux officiated because Rouen was without a pastor ${ }^{120}$.

Theoderic also inadvertently addresses issues of a secular nature within his narrative. The significance of the architectural details mentioned during the account of the riot has already been examined in full elsewhere ${ }^{121}$. We are also given insight into the role of the local vicomte (unnamed, but most likely Ansfredus), who is said to have raised troops under the royal ban (regis bannum) to

113. JAFFÉ, $1885-1888$, i, nº. 5074 .

114. Bessin, 1717, p. 66; see Foreville, 1976, p. 24 for discussion.

115. Theoderic gives no date for this event, but it seems to belong to the year 1078 , for he wrote that John had been struck with paralysis a few months before the feast day; if he was describing the celebration of 1077 that would only be a month after John's stroke of late July.

116. According to an agreement drawn up between Archbishop Maurilius and Nicholas, abbot of Saint-Ouen, which regulated the arrangements for the feast of St. Ouen, the bishop of Évreux would have already been present in Rouen, having officiated at vespers on the day itself, Arch. dép. Seine-Maritime, 14 H 156. For a critical edition, see Allen, 2009, ii, Appendix G, nº. 57.

117. ForeVille, 1976, p. 22.

118. Mirville, Seine-Maritime, cant. Bolbec.

119. BATES, 1998, $\mathrm{n}^{\circ} .164$.

120. De libertate Beccensis monasterii, in Constable and Smith, 2008, p. 138. The existence of a papal letter, sent to an unnamed archbishop of Rouen on 20 April 1079 commanding him to accept the primacy of Lyons (JAFFÉ, 1885-1888, i, nº 5126), has led some to argue that John was still archbishop at this date (BRINKWORTH, 1966, p. 72). However, it was not unknown for unnamed documents to be addressed to vacant sees, Johnson and Cronne, 1956, ii, $n^{\circ}$. 1389. I owe this observation to Stephen Marritt.

121. Allen, (forthcoming). 
rescue the archbishop ${ }^{122}$. Such behaviour provides no new information on the functions of a local vicomte, but is important in confirming those established elsewhere ${ }^{123}$. The reference to the fact that Duke William was delayed at Le Mans with his expedition (Cinomannis cum expeditione sua morabatur) also highlights a number of interesting issues ${ }^{124}$. Not least of these is the illustration of the dual role played by Norman clergy in the eleventh century. Both Abbot Nicholas and Archbishop John are said to have been among the nobles (precores) advising the duke, and it is noted in particular that John was a man "of wise counsel". That an archbishop should provide advice on military matters ought not surprise us. The dioceses of Coutances and Bayeux were occupied at this time by the most famous of "warrior-bishops" (Geoffrey de Montbray and Odo), and John was himself a member of one of the most important military frontier families of the duchy ${ }^{125}$. With his elder half-brother occupying the bishopric of Bayeux until 1049, it is likely that he was initially intended to occupy a secular role within the governance of the duchy. It was perhaps only due to political expediency, and Duke William's desire to consolidate his power in the Avranchin (another border region), that John, in his early forties and without ever having taken Holy Orders, accepted his appointment to the episcopate ${ }^{126}$. His background would have therefore made him a particularly useful counsellor, able to dispense advice as easily on military matters as those of the church.

What is more interesting, however, is not that the meeting took place, but when and where. The events of 1073 are among the more obscure of the Conqueror's reign. Early in the year he launched a campaign into Maine, and, according to Orderic, he quickly subdued garrisons at Fresnay and Sillé, before entering Le Mans ${ }^{127}$. Diplomatic evidence appears to corroborate this version of events, as William confirmed two Manceaux charters at Bonneville-sur-Touques on 30 March $^{128}$. He had returned to England by 1074, for it was from here that he left for Normandy early in that year ${ }^{129}$. The evidence in the Saint-Ouen version of the $A A R$ is therefore highly significant, for it allows us to determine at least one location for the Conqueror during the nine months between the end of his

122. Ansfredus occupied the position from $1055 \times 1066-1081$, Bouvris, 1985, p. 161.

123. Yver, 1969, p. 325-330. For more complete bibliographical details of work dedicated to the vicomte, see Bouvris, 1986, p. 149, n. 1.

124. There can be no doubt that Cinomannis should be translated as Le Mans, rather than simply Maine, and that the author meant to imply William was in the city, rather than contemplating an attack elsewhere, for he uses the locative, which for 1st declension nouns (Cinomanna, Cinomannae) is the ablative plural. For translation of Cinomannis as Le Mans elsewhere, see OV, ii, p. 306.

125. His father was Ralph, count of Ivry. For his career, see BAUduIN, 2004, p. 197-209.

126. This age is based on the terminus a quo of the first and only mention of his mother in a charter of 1011, and the terminus ad quem of his father's last known donation of $1015 \times 1017$, FAuroux, $1961, n^{\circ} .13$ (Albereda), $n^{\circ} .21$ (Rodulf).

127. OV, ii, p. 306-308.

128. For details of William's itinerary, and discussion of the diplomatic evidence, see BATES, 1998, p. 75-84, esp. p. 76, 79-80; Douglas, 1964, p. 449-453.

129. William was back in Normandy at the latest by May, where he attested a charter at Rouen, BATES, $1998, n^{\circ} .261$. 
March campaign in Maine, and his return to England. The circumstances that forced William to return to Maine in August 1073 are unclear. David Douglas long ago established an accepted chronology for the Conqueror's military campaigns between 1073 and $1081^{130}$, and no clear evidence exists to suggest William's presence in the county until a charter of $1077 \times 1078$, confirmed by William in Le Mans ${ }^{131}$. Trouble had erupted in Maine before this date, when Fulk le Réchin, count of Anjou (1068-1109), made his first unsuccessful attack on La Flèche, but this did not occur until 1076 or early $1077^{132}$.

Unfortunately, there is no evidence recording any military activity in the region in 1073, outside that which took place in its early months. Consequently, we are forced to conclude one of two things. Either Theoderic, who was writing almost twenty years after the events he describes, is in error, or Orderic Vitalis, who provides the only detailed account of events in Maine in 1073, is himself confused $^{133}$. That Theoderic is wrong seems unlikely for a number of reasons. The year is definitely correct, as the tumult at Saint-Ouen is recorded in various Norman annals under the year $1073^{134}$, while the premise that John was in Le Mans is the whole reason that he was late for the feast day Mass of St. Ouen and that it was celebrated without him. Alternatively, the reference that William was in Le Mans cannot refer to March of 1073, as John would not have taken almost five months to get from Le Mans to Rouen, and we are told the reason that he left the duke was that the feast day of St. Ouen was imminent. Professor Douglas noted that Orderic is himself confused on other Maine matters, but while his account of the treaty of Blancheland is mistaken, it cannot have occurred at any other date than 1081, as the so-called Annales of Renaud confirm a treaty was made between William and Fulk le Réchin in this year ${ }^{135}$. The $A A R$ therefore contains a reference to a previously unknown military campaign of the Conqueror in Maine. It is simply unfortunate that no other source corroborates this event, and that there is no indication as to what prompted William to return to the county in the first place.

\section{Reception of the $A A R$}

Unlike the Annals of Rouen and the Metrical chronicle of the Archbishops, the AAR did not enjoy a wide dissemination ${ }^{136}$. Only the abbey of Saint-Ouen reproduced the text, and then essentially hijacked it for its own purposes. The earliest known author to use the $A A R$ is Orderic Vitalis, who seems to have relied upon it for his

\footnotetext{
130. Douglas, 1964 , p. 401-407.

131. BATES, $1998, \mathrm{n}^{\circ} .174$.

132. Douglas, 1964, p. 403-405.

133. OV, ii, p. 306-308.

134. Chronicon Rotomagense..., p. 367; Annales de Jumièges..., p. 58; Annales Uticenses..., p. 158.

135. Annales de Rainaldi Archidiaconi sancti Mauricii Andegavensis, in Halphen, 1903, p. 88.

136. The Annals had been copied at Saint-Wandrille by 1066, at Saint-Évroult by 1098, at Mont-SaintMichel and Fécamp from c. 110o, at Saint-Étienne de Caen from c. 1100-1106, and at Jumièges from 1106, Annales de Jumièges..., p. 8-10. The Metrical chronicle was recopied by the monks of Saint-Ouen, the monastery at Mortemer and Orderic Vitalis, Bibl. mun. Rouen, ms Y 41 Omont 1406, fol. 13r-16r (Saint-Ouen); BnF, ms lat. 4863, fol. 112r-v (Mortemer); OV, iii, p. 50-94.
} 
section on the archbishops of Rouen ${ }^{137}$. It is not clear why the text was not reproduced elsewhere, but its limited appeal to those institutions without a direct link to the archbishops of Rouen probably did little to help. Within a few years of its composition the text was also robbed of two of its most important patrons. John's short archiepiscopate was cut even shorter by his incapacitating stroke of 1077, while Fulbert the archdeacon, one of the possible authors, was dead by c. $1075^{138}$. Governing the province during the turbulent years of Robert Curthose (1087-1106), William Bona Anima may have had little appetite for continuing the work. If he did ever review the status of the $A A R$ he may have seen it as a lost cause, for it had perhaps already been commandeered by the abbey of Saint-Ouen, while the archbishop was perhaps himself engaged in a much grander project-the Norman Anonymous-which sought to define the position of the Norman church within Europe $^{139}$. The AAR did continue to live on within the Rouen community, however, and it not only provided the inspiration for a later chronicle of the archbishops, but was itself extended to include the deeds of later archbishops ${ }^{140}$.

\section{Previous editions}

Jean Mabillon was the first editor of the AAR, in Veterum analectorum tomus I [-IV], 4 vol., Paris, Louis Billaine, 1675-1685, ii, p. 424-457. This was republished in a new edition after his death in Vetera analecta, Paris, Montalant, 1723, p. 222226. Other later editions include those of Edmond Martène, Veterum scriptorum et monumentorum collectio nova, Rouen, Guillaume Behourt, 1700, part II, p. 233-248, who, as has been noted above, may have worked from a now lost version of the text, and Jacques-Paul Migne, $P L$, 1844-1864, cxlvii, cols. 9-14 and 273-280, who republished Mabillon's second edition. Extracts have also been published in various collections ${ }^{141}$. Mabillon's edition is reasonably conscientious, but there are numerous errors: accurate reproduction of the medieval punctuation and diphthong usage is non-existent, verbs have had their tenses changed, words are omitted, and sometimes they are included when they are not present in either manuscript version of the text. The editions of both Migne and Martène also contain mistakes, the significance of the latter having already been discussed in full. The $A A R$ was reproduced only once in the twentieth century, when Louis Violette translated it into French (without the Latin text) as part of a collective work celebrating the history of Rouen cathedral, La cathédrale de Rouen, seize siècles d'histoire, dir. J.-P. Chaline, Rouen, 1996, p. 49-60.

\footnotetext{
137. OV, iii, p. xxvi-xxvii; Violette, 2005, p. 75.

138. SPEAR, 2006, p. 206-207.

139. Williams, 1951, p. 102-125.

140. For bibliographical details see above n. 27.

141. Bessin, 1717, p. 63-64; MANSI, 1757-1798, xx, cols. 395-398; Recueil des historiens..., 1869-1904, xi, p. 70-73; GILES, 1844, i, p. 363-366.
} 


\section{The present edition}

The present edition is based on $\mathbf{A}$, with the interpolations of $\mathbf{B}$ printed in italics. To avoid confusion, quotation marks are used to indicate reported speech, scriptural quotations and letter extracts, although neither author of the $A A R$ uses them. Since it is believed the edition printed by Martène is taken from a lost manuscript, the variants of his edition are also noted under the sigla $\mathbf{M}$. With regards to variant readings, I have not tried to catalogue those concerning diphthong usage or words where classical practice has replaced " $c$ " with " $t$ ", e.g. provintice. The folio and page numbers of the two manuscripts are printed in square brackets in the Latin text, while full historical and bibliographical notes accompany the English translation. Every attempt has been made to preserve the medieval punctuation, though where necessary this has been modernised. Both versions of the $A A R$ are punctuated according to rules current at the time, although the Livre noir does not always follow the precedent set by its diocesan counterpart ${ }^{142}$. Two main stops are employed by the authors. Medial stops, which have the appearance of the modern full stop, mark a pause either between two parts of a sentence of rough equality, or between a main and a subordinate clause. The cathedral author tends to place these stops on the line, whereas Theoderic places them slightly above. When the medial point occurs in the middle of a sentence it is represented here as a comma. The other stop is the punctus elevatus, which looks like an inverted semicolon. Theoderic uses these more frequently, especially where the sentence simply consists of the names of a preceding and succeeding bishop, although his usage is otherwise consistent with that found in the Livre d'ivoire. The stop itself is used to indicate a change in pitch (the voice being raised at the end of the first clause and then dropped for the following), which may suggest that the $A A R$ was to be read aloud ${ }^{143}$. It is here replaced with a modern equivalent, while " $i$ " is used for the equivalent of " $i$ " and " $j$ ", and " $v$ " for consonantal " $u$ ". The following abbreviations are used in the critical apparatus: abbr. = abbreviation; al. = alius, alia, etc.; al. man. = alia manu(s); corr. = correxit (correctio, etc.); del. = delevit (deletum, etc.); exp. = expunxit; incer. = incertus, incerta, etc.; lac. = lacuna, lacunae, etc.; leg. = legere; lin. = linea $(\mathrm{m}) ;$ marg. = margine; om.$=$ omisit; pri. $=$ primus, prima, etc.; scr. = scripsit; sec. = secundus, secunda, etc.; sup. $=$ super; tot. $=$ totus, tota, etc.

142. For discussion of these rules, see Southern, 1972, p. xxv-xxxiv.

143. A description of the Livre noir by Jean-François Pommeraye suggests this was certainly the case by the seventeenth century, for he says the manuscript was "un recueil de Vies de Saints qu'on lisoit autrefois aux collations ou conferences qui se tenoient dans le chapitre ou dans le cloistre avant compiles", Pommeraye, 1662, p. 248. 
Illustrations and tables

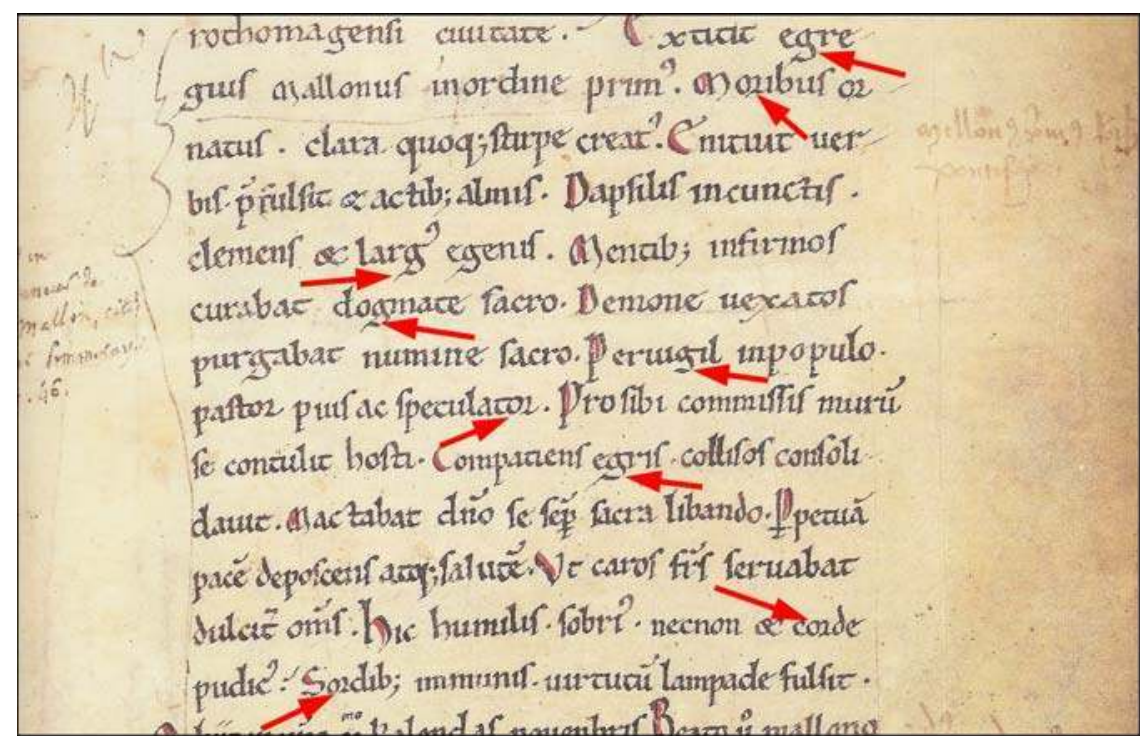

Fig. 1 : Distinctive single-story "g" and z-shaped " $r$ " of the first hand in the AAR of the Livre d'ivoire. Bibl. mun. Rouen, ms Y 27 Omont 1405, p. 26 (detail) Collections de la Bibl. municipale de Rouen. Photographie Thierry Ascencio-Parvy.

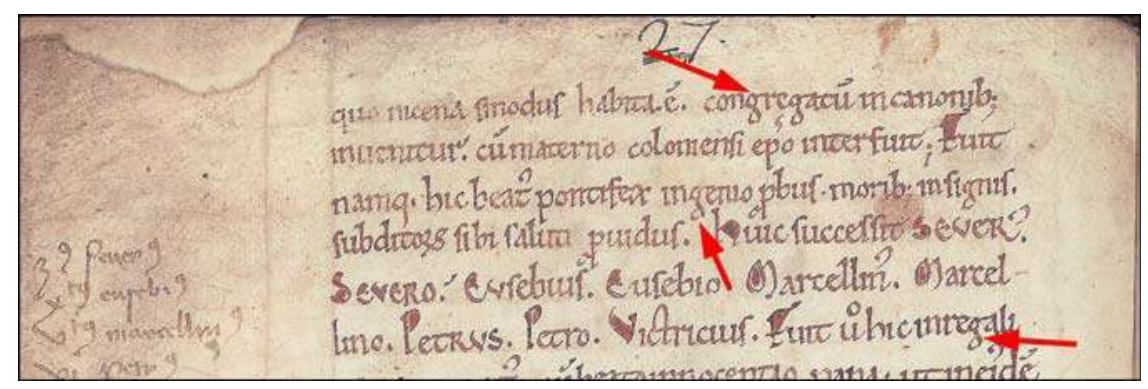

Fig. 2 : Two-story lower case "g" of the second hand in the AAR of the Livre d'ivoire. Bibl. mun. Rouen, ms Y 27 Omont 1405, p. 27 (detail)

Collections de la Bibl. municipale de Rouen. Photographie Thierry Ascencio-Parvy. 


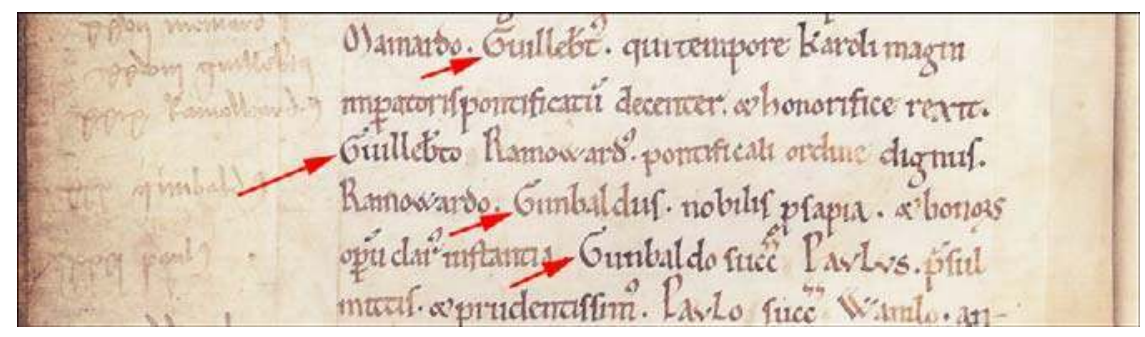

Fig. 3 : Distinctive capital "G" of the hand in the AAR of the Livre d'ivoire. Bibl mun. Rouen, ms Y 27 Omont 1405, p. 31 (detail)

Collections de la Bibl. municipale de Rouen. Photographie Thierry Ascencio-Parvy.

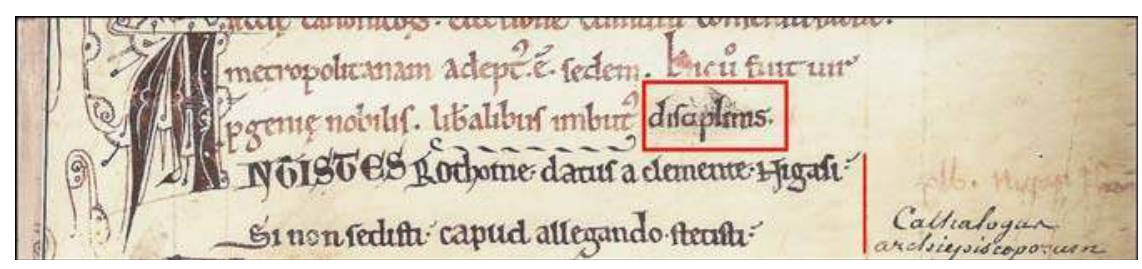

Fig. 4 : Last word of the in the AAR and the verse to St. Nicasius in the Metrical chronicle of the Livre d'ivoire. Bibl. mun. Rouen, ms Y 27 Omont 1405, p. 36 (detail) Collections de la Bibl. municipale de Rouen. Photographie Thierry Ascencio-Parvy. 


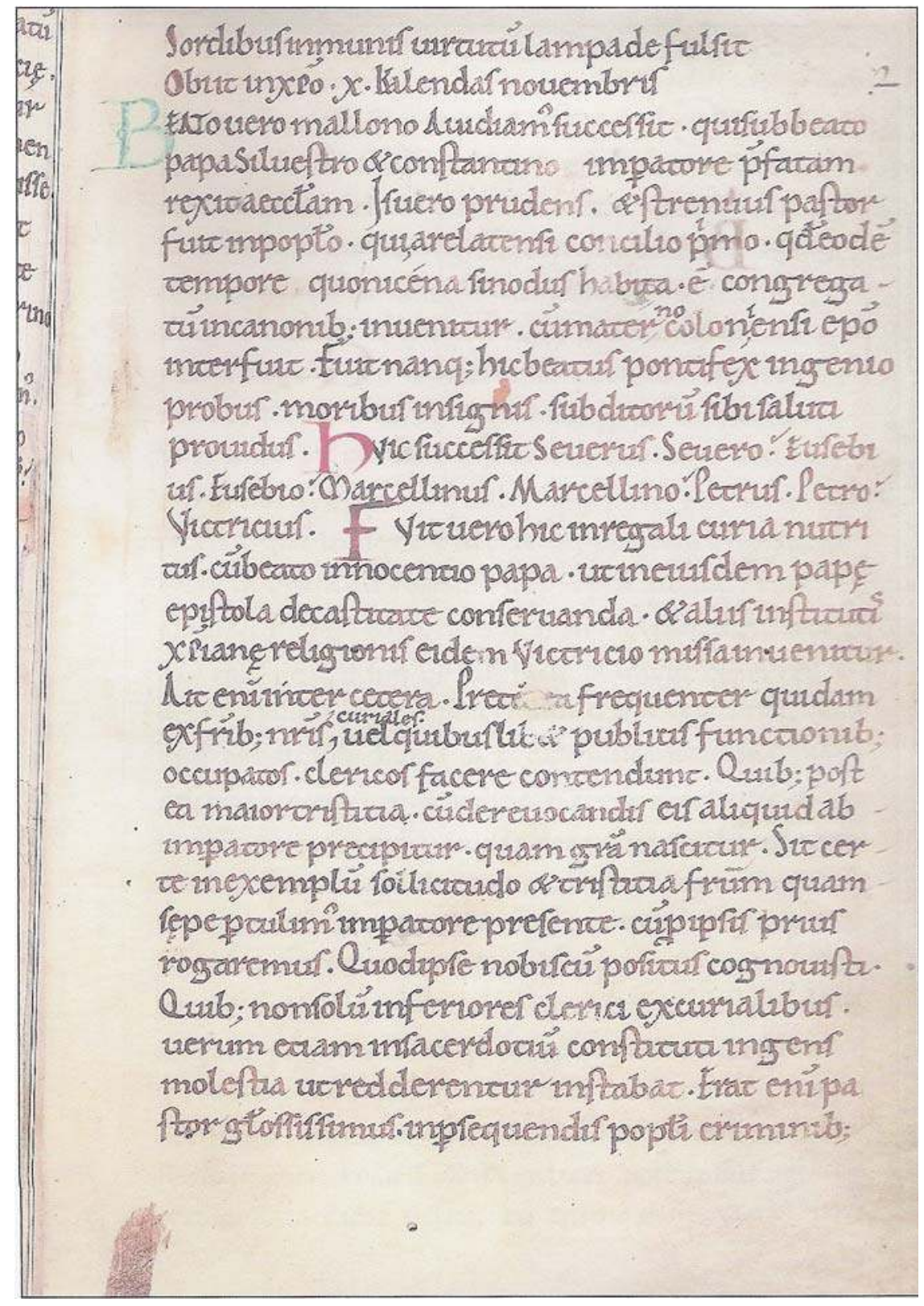

Fig. 5 : Bibl. mun. Rouen, ms Y 41 Omont 1406, fol. $2 \mathrm{r}$ Collections de la Bibl. municipale de Rouen. Photographie Thierry Ascencio-Parvy. 


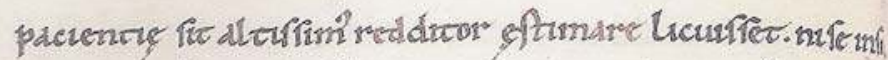

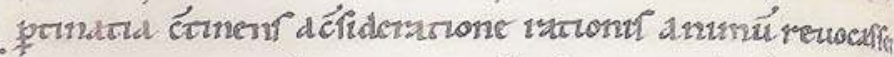

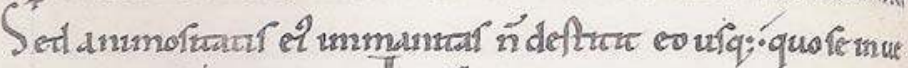

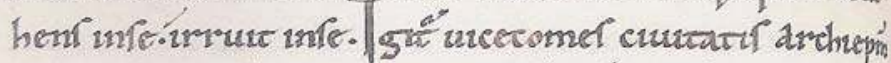

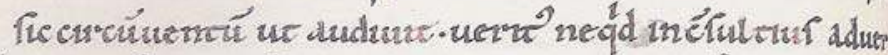

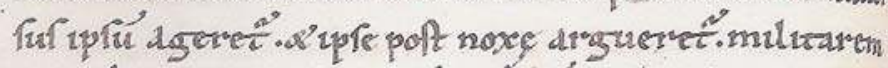

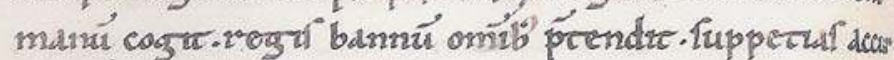

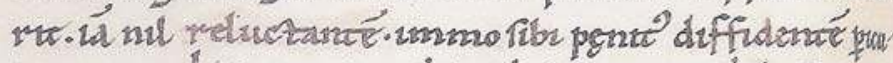

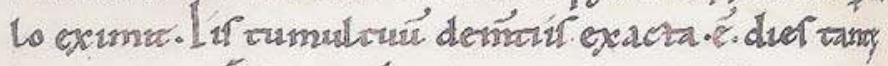

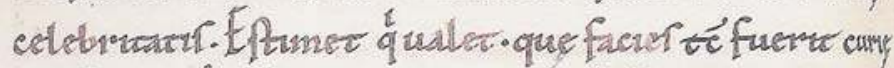
celefor.qua undugne vulem fur poedleneu înu curtiv dosvi fie éfurá. fie foedará fie propor dié fue remuntw

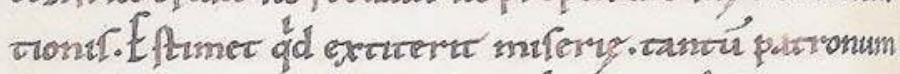

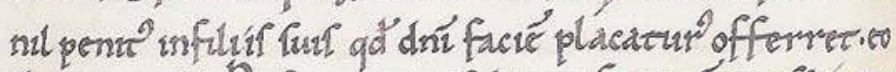

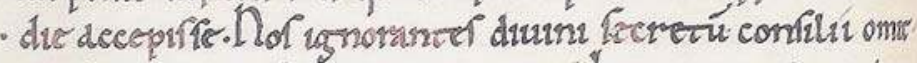
nm. de homusub humana periam. Incanca multrudint duferea fexu. ccare. oordme. ń eredinn defurfe: a qu mer camali fe mun nocurfte penumemr. dú nu medú quin cá fpeculi grudio proust forens dzcendexnn.d

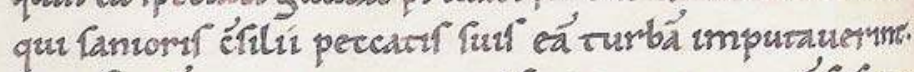

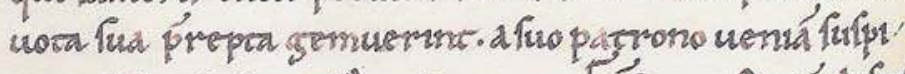

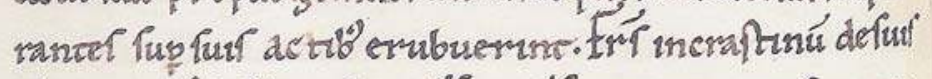
eluzun of of abbar fuo od factu fuern snmoreceret.

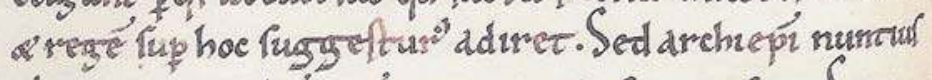

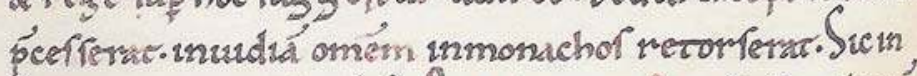
fecto negorw redicú eft. Rex luce poft up fut archupí

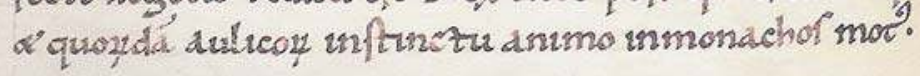

Fig. 6 : Bibl. mun. Rouen, ms Y 41 Omont 1406, fol. 9v

Collections de la Bibl. municipale de Rouen. Photographie Thierry Ascencio-Parvy. 


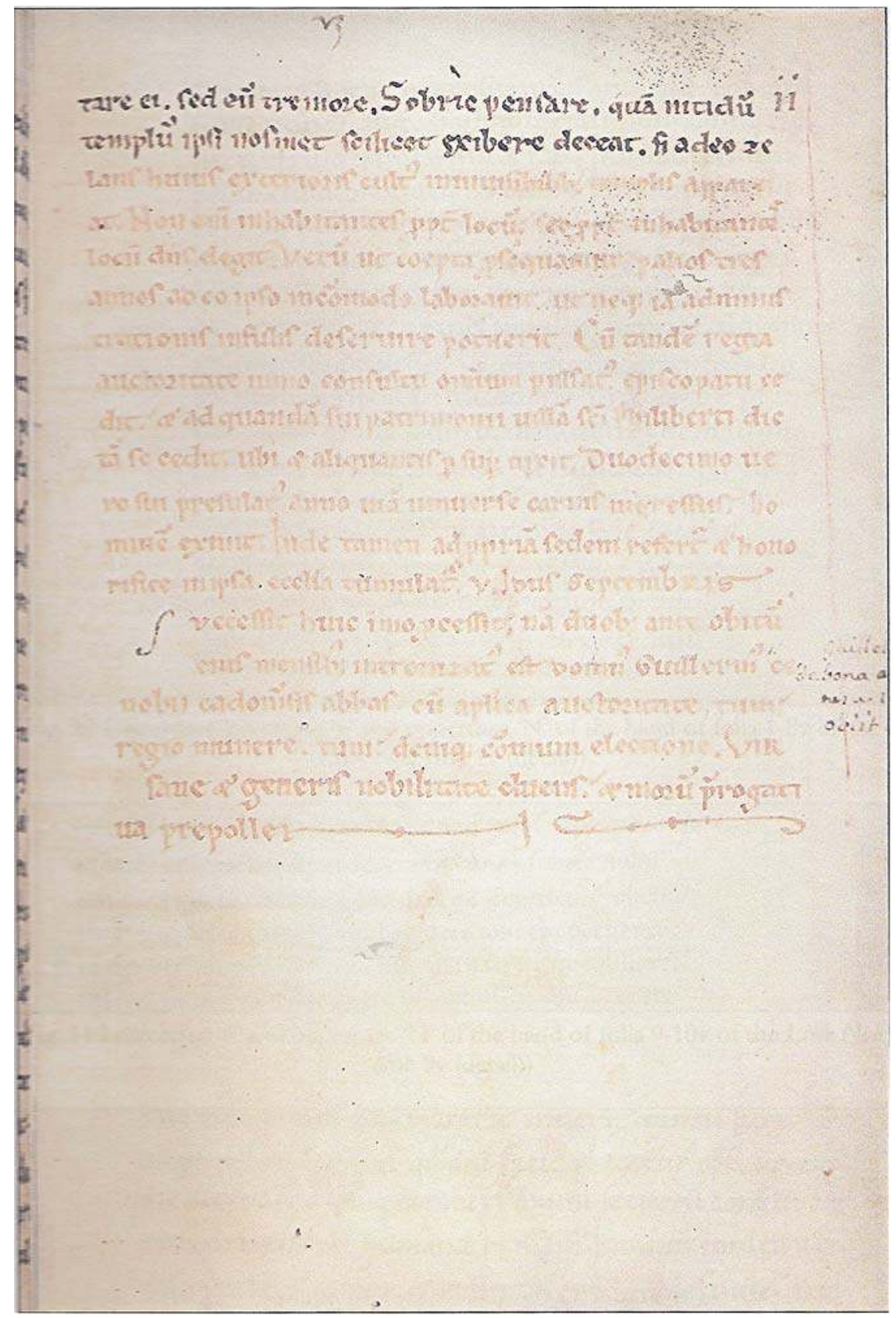

Fig. 7 : Bibl. mun. Rouen, ms Y 41 Omont 1406, fol. 11r Collections de la Bibl. municipale de Rouen. Photographie Thierry Ascencio-Parvy. 


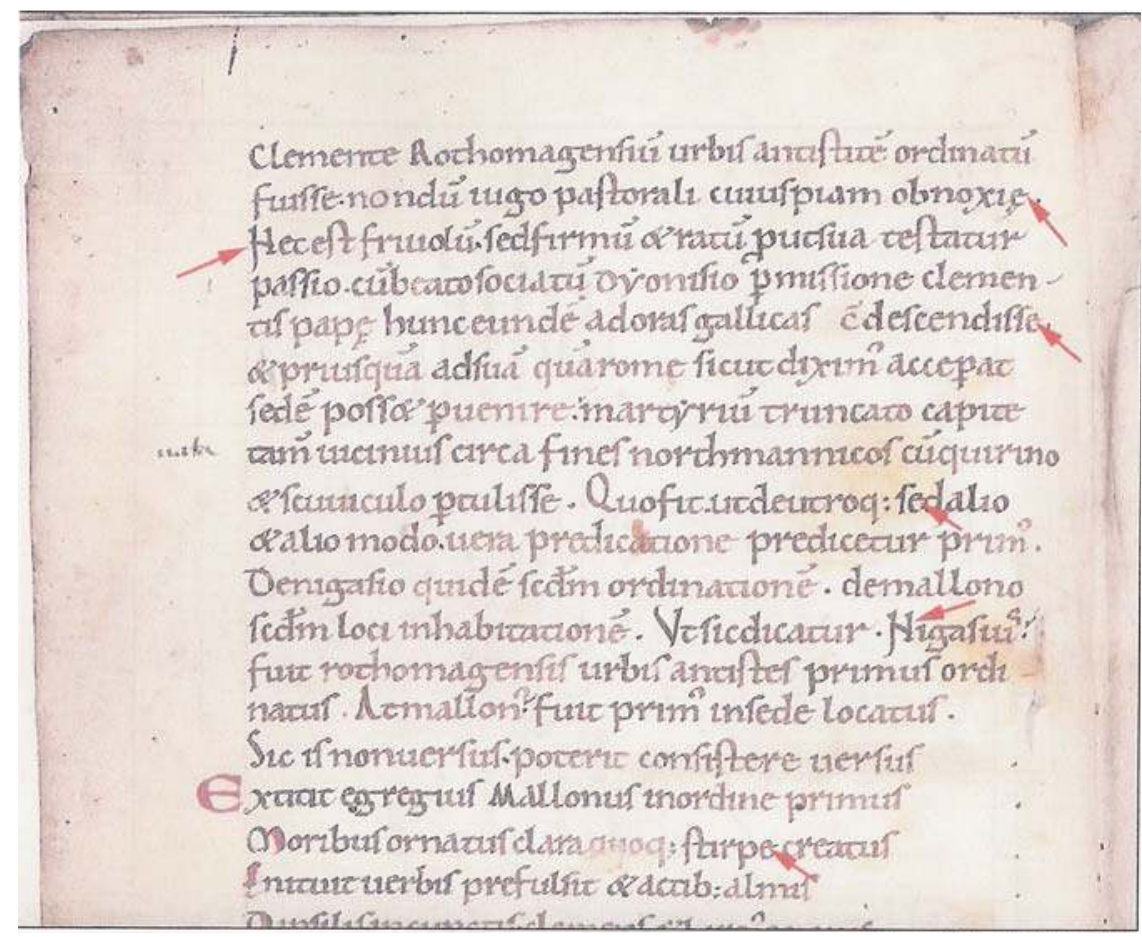

Fig. 8 : Distinctive lowercase " $\mathrm{e}$ " and uppercase " $N$ " of the hand of folios 1-8v of the Livre noir, fol. $1 \mathrm{v}$ (detail)

Collections de la Bibl. municipale de Rouen. Photographie Thierry Ascencio-Parvy.

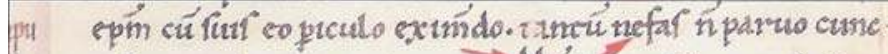

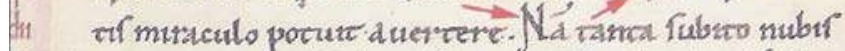

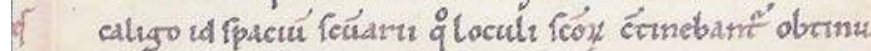

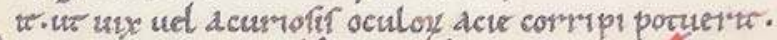

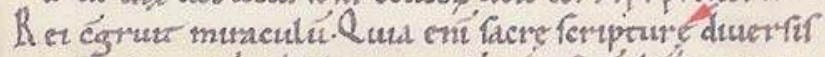

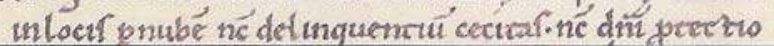

Fig. 9 : Lowercase "e" and uppercase " $\mathrm{N}$ " of the hand of folios 9-10v of the Livre noir, fol. 9v (detail)

Collections de la Bibl. municipale de Rouen. Photographie Thierry Ascencio-Parvy.

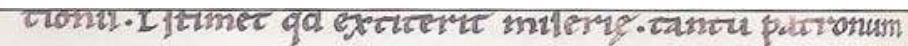

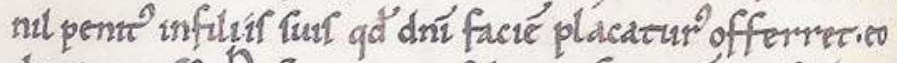

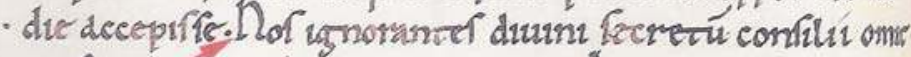
trm. de hom

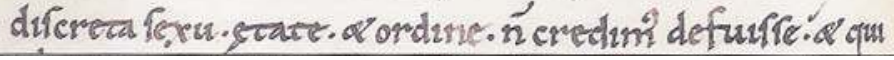

Fig. 10 : Looped form capital "N" on folio 9v of the Livre noir (detail)

Collections de la Bibl. municipale de Rouen. Photographie Thierry Ascencio-Parvy. 


\begin{tabular}{|c|c|c|c|}
\hline Folio & ms Y 41 Omont 1406 & Page & Martène \\
\hline \multirow[t]{2}{*}{$1 \mathrm{r}$} & $\begin{array}{l}\text {... Nigasium prænominatæ } \\
\text { civitatis primum antistitem... }\end{array}$ & 233 & $\begin{array}{l}\text {... Nigasium prænominatæ civitatis } \\
\text { antistitem... }\end{array}$ \\
\hline & ...nullatenus hac repugnatur... & & ...nullatenus hac repugnat... \\
\hline \multirow[t]{2}{*}{$1 \mathrm{~V}$} & ...sed firmum et ratum prout... & 234 & ...sed firmum et ratum pro $u t \ldots$ \\
\hline & $\begin{array}{l}\text {...vera predicatione predicetur } \\
\text { primus... }\end{array}$ & & $\begin{array}{l}\text {...vera predicatione predicetur } \\
\text { primum... }\end{array}$ \\
\hline \multirow[t]{2}{*}{$3 r$} & Ideo in tantum persecutus est... & 236 & Ideo in tantum prosequutus est... \\
\hline & $\begin{array}{l}\text { Modus expulsionis } s u \propto \text { talis } \\
\text { fuit. }\end{array}$ & & Modus expulsionis talis fuit. \\
\hline $4 \mathrm{~V}$ & $\begin{array}{l}\text { Precatus est autem præfatum } \\
\text { abbatem... }\end{array}$ & 238 & Precatusque præfatum abbatem... \\
\hline $5 \mathrm{r}$ & $\begin{array}{l}\text {...vir sapiens, et in cunctis } \\
\text { providus... }\end{array}$ & 239 & $\begin{array}{l}\text {...vir sapiens, et in multis } \\
\text { providus... }\end{array}$ \\
\hline \multirow[t]{4}{*}{$5 \mathrm{~V}$} & $\begin{array}{l}\text {...viro filio Hugonis de } \\
\text { Calvacamp... }\end{array}$ & & $\begin{array}{l}\text {...viro filio Hugonis de Cal- } \\
\text { vacaput... }\end{array}$ \\
\hline & $\begin{array}{l}\text {...et potentissimus, Ricardi } \\
\text { primi filius... }\end{array}$ & & ...et potentissimus, Ricardi filius... \\
\hline & $\begin{array}{l}\text {...et in mundialibus divitiis } \\
\text { adeo laudatus... }\end{array}$ & & $\begin{array}{l}\text {...et in mundialibus adeo } \\
\text { laudatus... }\end{array}$ \\
\hline & $\begin{array}{l}\text {...ceterisque } \\
\text { comprovintialibus... }\end{array}$ & 240 & ...ceterisque provincialibus... \\
\hline \multirow[t]{2}{*}{$6 r$} & $\begin{array}{l}\text { Qui nobili prosapia ex Remensi } \\
\text { pago exortus... }\end{array}$ & & $\begin{array}{l}\text { Qui nobili prosapia ex Remensi } \\
\text { agro exortus... }\end{array}$ \\
\hline & $\begin{array}{l}\text {...in Leodicensi æcclesia omni } \\
\text { liberalium... }\end{array}$ & & $\begin{array}{l}\text {...in Leodiensi æcclesia omnium } \\
\text { liberalium... }\end{array}$ \\
\hline $8 \mathrm{r}$ & $\begin{array}{l}\text {...et ab omni iure seu } \\
\text { consuetudine... }\end{array}$ & 243 & ...et ab omni iure seu consuedine... \\
\hline $8 \mathrm{v}$ & $\begin{array}{l}\text { Cum subito quidam meroris } \\
\text { impatiens... }\end{array}$ & 244 & $\begin{array}{l}\text { Cum subito quidam mœris } \\
\text { impatiens... }\end{array}$ \\
\hline $9 \mathrm{r}$ & ...in ipsa nube portendebatur... & 245 & ....in ipsa nube protendebatur... \\
\hline $9 \mathrm{v}$ & ...suis actibus erubuerint. & 246 & ...suis actibus erubuerunt. \\
\hline 1or & $\begin{array}{l}\text {...vero suum in futuro } \\
\text { vindictam... }\end{array}$ & & ...vero suum in futuro vindicta... \\
\hline $10 \mathrm{~V}$ & $\begin{array}{l}\text {...paucis ante mensibus paralisi } \\
\text { percussus... }\end{array}$ & 247 & $\begin{array}{l}\text {...paucis ante mensibus paralisi } \\
\text { perculsus... }\end{array}$ \\
\hline \multirow[t]{2}{*}{$11 \mathrm{r}$} & $\begin{array}{l}\text {...tres annos adeo ipso } \\
\text { incommodo... }\end{array}$ & 248 & ...tres annos adeo incommodo... \\
\hline & $\begin{array}{l}\text {...carnis ingressus, hominem } \\
\text { exiuit. }\end{array}$ & & ...carnis ingressus, hominem exuit. \\
\hline
\end{tabular}

Table 1 : Comparison between the Livre noir and the edition of the AAR by Martène. 


\begin{tabular}{|c|c|c|c|}
\hline Year & Location & Outcome & Source \\
\hline $1055 ?$ & Rouen & $\begin{array}{l}\text { Eucharistic confession of faith } \\
\text { against Berengar of Tours; or } \\
\text { imposition of celibacy on clergy }\end{array}$ & $\begin{array}{l}\text { (Berengar) Migne, PL, } \\
\text { 1844-1864, cxliii, cols. 1382- } \\
\text { 1383, Recueil des histo- } \\
\text { riens..., 1869-1904, xi, } \\
\text { p. 529; (celibacy) AAR, ms } \\
\text { Y } 27 \text { Omont 1405, p. 34-35 }\end{array}$ \\
\hline $1055 \times 1063 ?$ & Rouen & $\begin{array}{l}\text { Imposition of celibacy on } \\
\text { clergy }\end{array}$ & $\begin{array}{l}A A R, \text { ms Y } 27 \text { Omont } \\
1405, \text { p. } 34-35\end{array}$ \\
\hline $1061 ?$ & Caen & $\begin{array}{l}\text { Truce of God promulgated; } \\
\text { three canons: (i) abbots living } \\
\text { in country forbidden from } \\
\text { wandering around; } \\
\text { (ii) introduction of curfew; } \\
\text { (iii) criminals to be punished } \\
\text { according to law }\end{array}$ & Bessin, 1717, p. 47 \\
\hline 1 oct. 1063 & Rouen & $\begin{array}{l}\text { Imposition of celibacy on clergy; } \\
\text { repromulgation of confession } \\
\text { against Berengar of Tours? }\end{array}$ & $\begin{array}{l}A A R, \text { ms Y } 27 \text { Omont } 1405 \text {, } \\
\text { p. } 34-35 \text {; for Berengar cf. } \\
\text { Migne, } P L, 1844-1864, \text { col. } \\
1383 \text { and BESsin, } 1717, \text { p. } 49\end{array}$ \\
\hline 1064 & Lisieux & $\begin{array}{l}\text { Ten canons; provision for well } \\
\text { being of church and continuation } \\
\text { of work done by earlier councils; } \\
\text { consideration of the doctrine of } \\
\text { the Trinity and Eucharist }\end{array}$ & DELISLE, 1901, p. 516-521 \\
\hline
\end{tabular}

Table 2 : The councils of archbishop Maurilius, 1055-1064. 


\section{Edition}

\section{[Acta archiepiscoporum Rotomagensium]}

Gallię provincię sunt .x. ${ }^{144}$ et .viii. ${ }^{\text {to }}{ }^{145}$, quarum una existit que vocatur Lugdunensis .ii. ${ }^{146}$, in qua est nobilis et ampla civitas, quę vocatur Rodomus vel Rothomagus ${ }^{147}$, super fluium ${ }^{148}$ Sequane sita. Huius civitatis ęcclesia in honore beatę et gloriosę Dei genitricis semper virginis Marię est consecrata. Hęc vero est metropolis. Sex enim sub se civitates episcopales continet, scilicet primam civitatem Baiocatarum. Secundam civitatem, Abrincatarum. Terciam civitatem, Evatinorum, que dicitur Ebroicas. Quartam civitatem, Salanum, que vocatur Sagium. Quintam civitatem, Lexoviorum. Sextam civitatem, Constantinorum.

In prefata Rothomagensi civitate, ${ }^{149}$ extitit egregius Mallonus in ordine primus. Nonnullos horum positio verborum perturbat, non satis idonee speculantes, quoniam eorum velle, scilicet beatissimum Nigasium prenominate civitatis primum ${ }^{150}$ antistitem extitisse, nullatenus hac repugnatur ${ }^{151}$, si expositione quantulumcumque subtili fulciatur. Attendant igitur tam clerici quam monachi ne errent, qualiter scripturas perspicatius indagantes utrumque posse haud inconvenienter stare diiudicent. Decenter inquam, inquiunt, qui Mallonum in sede Rothomagensi fuisse primum asserunt. Nullus enim eum preivit, quantum ad archiepiscopatus usumfructum. Nec tamen male predicant, qui beatum Nigasium eiusdem sedis archiepiscopum fuisse primum comprobant. Quippe iam non paucis reor manifestatum esse, hunc Romę a beato papa [B iv] Clemente Rothomagensium urbis antistitem ordinatum fuisse, nondum ingo pastorali cuiuspiam obnoxię. Nec est frivolum, sed firmum et ratum prout ${ }^{152}$ sua testatur passio, cum beato sociatum Dyonisio ${ }^{153}$ permissione Clementis pape hunc eundem ${ }^{154}$ ad oras Gallicas condescendisse, et priusquam ad suam quam Rome sicut diximus acceperat sedem posset pervenire, martyrium truncato capite tamen vicinius circa fines Northmannicos cum Quirino et Scuviculo pertulisse. Quo fit, ut de utroque sed alio et alio modo, vera predicatione predicetur primus ${ }^{155}$. De Nigasio quidem secundum ordinationem, de Mallono secundum loci inhabitationem. Ut sic dicatur, Nigasius fuit Rothomagensis urbis antistes primus ordinatus. At Mallonus, fuit primus in sede locatus. Sic is non versus, poterit consistere versus.

\footnotetext{
144. .x.] decem BM.

145. .viii. $\left.{ }^{\text {to }}\right]$ octo $\mathrm{M}$.

146. que vocatur Lugdunensis .ii. $\left.{ }^{a}\right]$ Lugdunensis quę vocatur secunda BM.

147. Rothomagus] scr. sine -h- per tot. M.

148. fluium] fluvium BM.

149. Rothomagensi civitate] civitate Rothomagensi BM.

150. primum] om. $\mathbf{M}$.

151. repugnatur] repugnat $\mathbf{M}$.

152. prout] pro ut $\mathbf{M}$.

153. Dyonisio] Dionysio M.

154. eundem] eumdem $\mathbf{M}$.

155. primus] primum $\mathbf{M}$.
} 
Extitit egregius Mallonus in ordine primus, Moribus ornatus, clara quoque stirpe creatus. Enituit verbis, prefulsit et actibus almis, Dapsilis in cunctis, clemens et largus egenis. Mentibus infirmos curabat dogmate ${ }^{156}$ sacro, Demone vexatos purgabat numine sacro. Pervigil in populo pastor pius ac speculator, Pro sibi commissis murum se contulit hosti. Compatiens egris, collisos consolidavit. Mactabat Domino se semper sacra libando ${ }^{157}$, Perpetuam pacem deposcens atque salutem. Ut $\operatorname{caros}^{158}$ fratres, servabat dulciter omnes ${ }^{159}$, Hic humilis, sobrius, necnon et corde pudicus [B 2r].

Sordibus immunis ${ }^{160}$, virtutum lampade fulsit. Obiit in Christo .x. ${ }^{\text {mo }}{ }^{161}$ kalendas Novenbris ${ }^{162}$.

Beato vero Mallono Avidianus ${ }^{163}$ successit, qui sub beato papa Silvestro et Constantino imperatore prefatam rexit ecclesiam. Is vero ${ }^{164}$ prudens, et strenuus pastor fuit in populo, qui Arelatensi concilio primo quod eodem tempore [A p. 27] quo Nicena sinodus ${ }^{165}$ habita est congregatum in canonibus invenitur, cum Materno ${ }^{166}$ Coloniensi ${ }^{167}$ episcopo interfuit. Fuit namque ${ }^{168}$ hic beatus pontifex ingenio probus, moribus insignis, subditorum sibi saluti providus. Huic successit Severus; Severo, Eusebius; Eusebio, Marcellinus; Marcellino, Petrus; Petro, Victricius.

Fuit vero hic in regali curia nutritus, cum beato Innocentio papa, ut in eiusdem papę epistola de castitate conservanda, et aliis institutis Christianę religionis eidem Victricio missa invenitur ${ }^{169}$. Ait enim inter cętera. "Preterea frequenter quidam ex fratribus nostris, curiales ${ }^{170}$, vel quibuslibet pupblicis ${ }^{171}$ functionibus occupatos, clericos facere contendunt. Quibus postea maior tristitia, cum de revocandis eis aliquid ab imperatore precipitur, quam gratia nascitur. Sit certe in exemplum sollicitudo et tristitia fratrum quam sepe pertulimus imperatore

156. dogmate] docmate $\mathbf{B}$.

157. libando] litando BM.

158. caros] karos $\mathbf{B}$.

159. omnes] hostes BM.

160. immunis] inmunis $\mathbf{B}$.

161. .x. $\left.{ }^{\mathrm{mo}}\right]$.x. BM.

162. Novenbris] Novembris BM.

163. Avidianus] Avidiamus B.

164. vero] sed corr. ex sui A.

165. sinodus] synodus $M$.

166. Materno] -no sup. lin. B.

167. Coloniensi] -i- sup. lin. B.

168. namque] nanque $\mathbf{B}$.

169. invenitur] in marg. A

170. curiales] sup. lin. B.

171. pupblicis] sed corr. ex pupplicis A. publicis BM. 
presente, cum pro ipsis ${ }^{172}$ prius rogaremus. Quod ipse nobiscum positus cognouisti. Quibus non solum inferiores clerici ex curialibus, verum ætiam in sacerdotium constituti ingens molestia ut redderentur instabat". Erat enim pastor gloriossissimus inpersequendis populi criminibus [B $2 \mathrm{v}$ ] rigidus, viduarum et orphanorum pater mittissimus, misericors pauperibus, cunctis compatiens infirmis et dolentibus.

Cui successit, Innocentius; Innocentio, sanctus Evodus; Evodo, Silvester; Silvestro, Malsonus; Malsono, Germanus; Germano, Crescentius; Crescentio vero, beatus Gildardus, frater beati Medardi, quorum vitam magnifico stilo beatus Fortunatus scribit. Una enim die nati fuerunt, una ætiam die, ordinati, una quoque die migraverunt ad ${ }^{173}$ Christum.

Gildardo successit beatus Flavius, cuius pontificatus tempore [A p. 28] constructa est æcclesia in honore beati Petri apostoli, in suburbio urbis Rothomagensis, anno primo Lotharii regis Francorum, nobiliter ædificata, in qua corpus beati Audoeni successoris sui sepulturę traditum est. Hic vero beatus Flavius, anno quingentesimo, Dominicę Incarnationis, multis virtutibus preditus ${ }^{174}$, divini amoris flagrantia accensus, dapsilis pauperibus ${ }^{175}$, Rotomagensem rexit æcclesiam.

Huic successit Pretextatus, vir magnę sanctitatis, et omnibus iniquis odiosus. Hic vero fuit tempore Chilperici regis filii Clotharii, qui vir nimię crudelitatis cum Fredegonde ${ }^{176}$ impia uxore sua, ingenti contra pontificem odio exarsit. Causa vero odii nil ${ }^{177}$ aliud fuit nisi quia fratrem suum Sigibertum ${ }^{178}$ regem qui fraude Chilperici occisus fuit, multum dilexerat, et eandem ${ }^{179}$ dilectionem Childeberto filio eius et matri Brunichildi ${ }^{180}$ servabat. Hac ${ }^{181}$ de causa iratus Chilpericus sibi calumniam ${ }^{182}$ inposuit ${ }^{183}$, scilicet quod magnam partem [B $3 \mathrm{r}$ ] thesauri fratris sui Sigiberti ${ }^{184}$, apud se reconditam habuerat, quam postquam Childebertus nepos eius litem contra eum inierat, ei rediderat ${ }^{185}$. Ideo in tantum persecutus ${ }^{186}$ est eum quod eum ab episcopatu destitutum expulit, et in quandam insulam in Constantinensi pago in mari sitam exulavit ${ }^{187}$, et in loco eius Melantium archidiaconum, episcopum ordinari fecit.

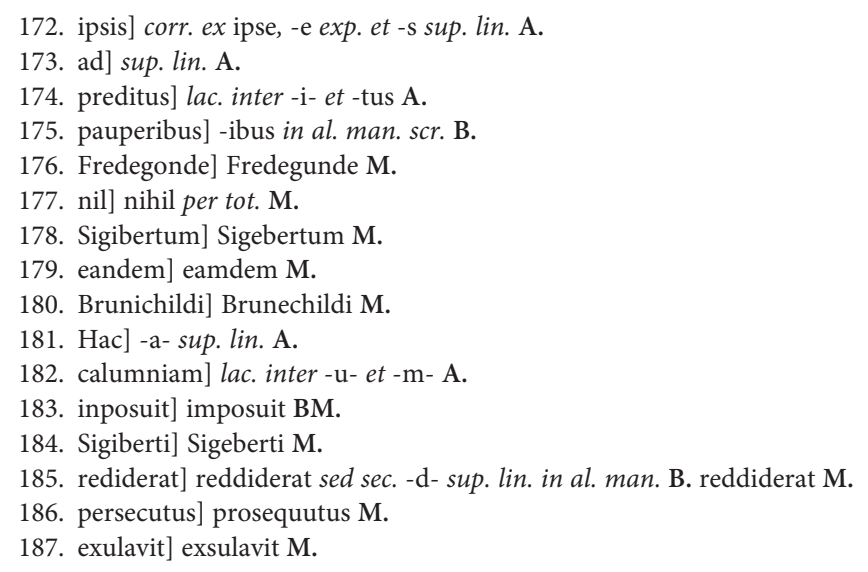


Modus expulsionis suę ${ }^{188}$ talis fuit. Rex concilium episcopos suos convocare fecit. Cui vir magnę auctoritatis, et probitatis Gregorius archiepiscopus Turonensis interfuit. Hic vero nec callidę machinationi ${ }^{189}$ qua episcopus deceptus est nec iniustę destitutioni assensum prebuit. Rex vero impia calliditate quibusdam episcopis [A p. 29] mandavit ei, quod si quę sibi obiecerat ${ }^{190}$ in concilio recognosceret et inde coram rege prostratus se reum proclamaret, omnino ei dimitteret. Qui ortatu ${ }^{191}$ impiorum coepiscoporum deceptus, fraudulentis regis mandatis ${ }^{192}$ adquievit. Tunc rex clamare cępit. "Audistis ${ }^{193}$ eum crimine convictum, nunc super hoc certam sententiam definite" ${ }^{194}$. Et ita deposuerunt eum, et in prefatum exilium ${ }^{195}$ rex retrudere iussit. Mortuo vero rege, omnium primatum et coepiscoporum consilio et iuditio, nolente Fredegonde ${ }^{196}$ regina, ad propriam æcclesiam est revocatus, et deposito Melantio in propriam sedem intronizatus ${ }^{197}$. Melantius vero in ${ }^{198}$ familiaritate Fredegondis ${ }^{199}$ impiissimę reginę permansit, quę beato Pretextato semper inimicata, et insidiata ${ }^{200}$ est in [B 3V] tantum ${ }^{201}$, ut pretio quorundam mentes cum prefato Melantio corrumperet, ita ut sicut beatus Gregorius Turonensis in scriptis suis narrat, nocte sancta Paschę in loco pontificali ubi stare consueverat, gladiis eum ${ }^{202}$ percuterent, et ita interficerent. Qui mox ut vulnera sensit, ad altare cucurrit, et illud amplexatus, viatico Dominici corporis, et sanguinis se muniens animam Deo reddidit; corpus vero eius omnes principes patrię cum magno eiulatu, et lamæntatione de tanti pastoris patrocinii desolatione, condolentes sepulture honorifice tradiderunt. Postea vero Melantius qui tempore sui exulatus ${ }^{203}$ episcopatum usurpaverat, consilio et ingenio prefatę reginę in eadem sede est restitutus.

Huic successit presul Hildulfus, vir prudens, et honestus. Hildulfo ${ }^{204}$ beatus Romanus, nobilis ortu, et virtute preclarus. Beato ${ }^{205}$ Romano, sanctus Audoenus, claris natalibus ortus, [A p. 30] et virtutum magnitudine exelsus ${ }^{206}$. Beato Audoeno successit, inclitus ${ }^{207}$, Ansbertus, venerabilis presul, et sanctis operibus

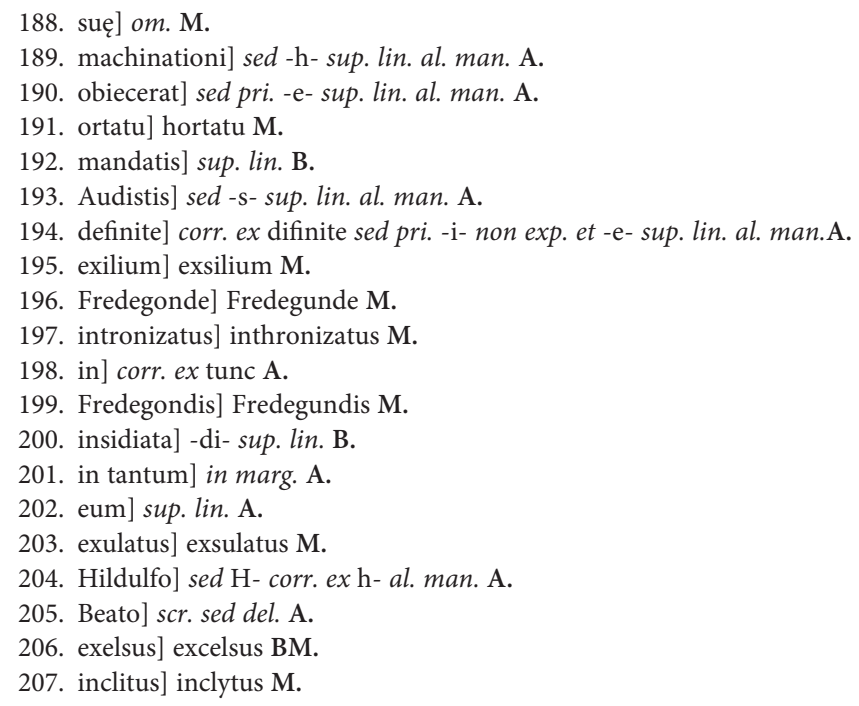


gloriosus. Horum vero trium ${ }^{208}$ ac beati Gildardi memoriam tantum tetigimus, quia eorum gesta a probatissimis viris luculenter apud nos conscripta habentur.

Ansberto successit venerabilis Grippo. Gripponi, Ranilandus, vir venerabilis et honestus ${ }^{209}$. Ranilando sanctus Hugo. Qui venerabilis vitę et magnę honestatis fuit ${ }^{210}$, ut vita eius testatur. Hugoni, Ratbertus, vir prudens et strenuus. Ratberto, Grimo. Hic ${ }^{211}$ nanque ${ }^{212}$ vir magnę nobilitatis et probitatis extitit, populumque sibi creditum tam bonorum [B $4 \mathrm{r}$ ] operum exemplis, quam predicationibus optime gubernavit, æcclesiamque sanctę Dei genitricis Marię cuius sedi pręsederat ${ }^{213}$, propriis prediis, ac pluribus beneficiis augmentavit. Fontanas enim ${ }^{214}$ super fluvium Itonam sitas, cum omnibus suis ${ }^{215}$ apenditiis ${ }^{216}$ dedit. Grimoni successit Rainfredus, vir nobili progenie ortus, et litterarum studiis imbutus, qui æcclesiam propriis beneficiis augmentavit. Dedit enim ei in territorio Villicasino ${ }^{217}$ villam quę dicitur Cramisiacum, et quamplurima beneficia ex nobilibus viris ad opus suę æcclesię adquisivit.

Rainfredo successit beatę memorię Remigius. Hic ${ }^{218}$ fuit filius Karoli ${ }^{219}$, qui maior domus regię apellatus ${ }^{220}$ est frater Carlomagni ${ }^{221}$ qui relicta parte regni quam possidebat, in monte Sorepte monachus effectus est, ubi æcclesiam in honore sancti Silvestri construxit, et inde ad monasterium ${ }^{222}$ sancti Benedicti in monte Casino ${ }^{223}$ transiit. Fuit etiam idem Remigius frater Pipini quem Stephanus papa regem consecravit. Hic ${ }^{224}$ vero Pipinus precibus Carlomagni monachi fratris sui ${ }^{225}$ mandavit Remigio prefato archiepiscopo ut ad locum qui dicitur Floriacus pergeret ${ }^{226}$ et corpus sancti Benedicti qui ibi requiescebat, legatis [A p. 31] Carlomagni redderet. Cumque ad locum veniret, et abbatem qui tunc temporis monasterium regebat, et Medo dicebatur vocaret, regis edicta edisserens ${ }^{227}$, cum legatis Karlomagni æcclesiam ingressus est. Cumque sepulchrum ${ }^{228}$ beati

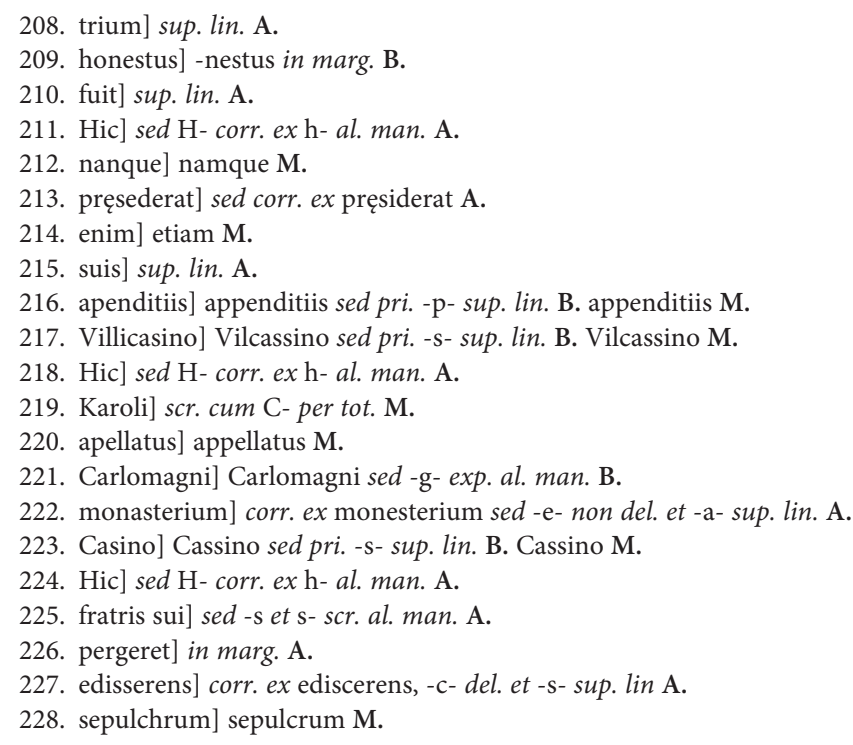


viri appropinquassent, repentina cecitate multati sunt. Proinde terrore valido concussi, ante prefatum abbatem fratresque ${ }^{229}$ [B 4V] loci illius solotenus prosternuntur, misericordiam deprecantes quatinus ${ }^{230}$ pro eis Dominum exorarent, ut eis indulgeret. Promititque ${ }^{231}$ beatus Remigius quod numquam ${ }^{232}$ sancti corpus inde amplius transferret. Quid plura? Ilico sunt exauditi, et beatus Remigius cum suis sodalibus pristinam sanitatem recepit. Precatus ${ }^{233}$ est autem ${ }^{234}$ prefatum abbatem ut corporis beati viri reliquias ${ }^{235}$ illis exiberet ${ }^{236}$, ne locus in quo Deo devote servierat, tanto patrocinio cassaretur, qui libenter adquievit. Sicque legatis ${ }^{237}$ remeantibus ${ }^{238}$ ad propria, beatus Remigius rediit ad sua. Ipse vero quam plura suę æcclesię adquisivit beneficia. Et de suis propriis largitus est multa. Super gregem sibi commissum vir nobilissimus pervigil, necnon moribus et opere clarus extitit, et beato fine quievit.

Beato Remigio, Meinardus ${ }^{239}$ venerabilis pontifex successit. Mainardo, Guillebertus, qui tempore Karoli magni imperatoris pontificatum decenter, et honorifice rexit. Guilleberto Rainowardus ${ }^{240}$, pontificali ordine dignus. Rainowardo $^{241}$, Gunbaldus ${ }^{242}$, nobilis prosapia, et bonorum operum clarus instantia. Gunbaldo successit Paulus, presul mittis ${ }^{243}$, et prudentissimus. Paulo successit Wanilo, antistes Deo devotus, et in cunctis reverentissimus. Waniloni, successit Adalardus, nepos Gunbaldi archiepiscopi, qui ${ }^{244}$ religiosus in cunctis operibus fuit. Adalardo, Riculfus, vir nobilis, et multis dives prediis, quibus æcclesiam sibi commissam hęreditavit. Fuit autem [B $5 \mathrm{r}$ ] tempore [A p. 32] Karoli regis patris Ludovici regis cuius fuit filius rex Lotharius, in quo progenies Karoli magni a regno funditus exstirpatur ${ }^{245}$. Hugo enim dux qui cognominatus ${ }^{246}$ est magnus, regnum sibi usurpavit, et rex consecratus est. Cui successit Rotbertus in regimine filius eius rex Deo devotus. Prefatus vero Riculfus cartas æcclesię supradictum regem fecit regali sanctione corroborare. Riculfo, successit Iohannes devotus ${ }^{247}$, et religiosus antistes. Iohanni, Witto, vir honorabilis, et reverentissimus pastor.

229. fratresque] corr. ex patresque, -p-del. et-fr- sup. lin. A.

230. quatinus] quatenus $\mathbf{M}$.

231. Promititque] Promittitque M.

232. numquam] nunquam $\mathbf{B}$.

233. Precatus] Precatusque M.

234. est autem] om. M.

235. reliquias] sed corr. ex leliquias A.

236. exiberet] scr. cum -h- per tot. M.

237. legatis] sup. lin. A.

238. remeantibus] -ibus scr. sed del. A.

239. Meinardus] Mainardus M.

240. Rainowardus] Rainouuardus sed-o- sup. lin. al. man. B. Rainovuardus M.

241. Rainowardo] Rainouuardo sed sec. -u- sup. lin. al. man. B. Rainovuardo M.

242. Gunbaldus] scr. cum -m- per tot. M.

243. mittis] mitis sed corr. ex miccis B. mitis $\mathbf{M}$.

244. qui] sup. lin. A.

245. exstirpatur] extirpatur M.

246. cognominatus] sed corr. ex. connominatus al. man. A.

247. devotus] lac. inter -e- et -v- B. 
Wittoni, Franco, prudens pontifex, et bonus populi auxiliator. Huius enim tempore Rollo dux Danorum patriam invasit, quę vocabatur ${ }^{248}$ Francia, nunc vero Normannia, eorum nomine insignita: cuius mentis feritatem tam divinis eloquiis quam devotis servitiis ita delinivit, ut terram sibi adquisitam cum pace, et iustitia regeret ${ }^{249}$. Postea predicatione prefati pontificis legem Christianam suscipiens, ab eodem baptizatus est, et in fide catholica perseverans bono fine migravit ad ${ }^{250} \mathrm{Christum}$. Franconi, successit Gunhardus vir sapiens, et in cunctis ${ }^{251}$ providus. Gunhardo, successit Hugo. Hic vero fuit prosapia clarus, sed ignobilis ${ }^{252}$ cunctis operibus. Monachus enim apud sanctum Dionisium ${ }^{253}$ erat, quando Willelmus filius Rollonis dux Normannorum ei episcopatum tradidit. Sed postpositis sanctę regulę institutis, carnis petulantię se omnino contulit. Filios enim [B 5v] quamplures procreavit. Ecclesiam et res æcclesię destruxit, Todiniacum enim qui in dominicatu archiepiscopi erat cum omnibus appenditiis suis fratri suo Radulfo potentissimo viro filio Hugonis de Cavalcamp ${ }^{254}$ dedit $^{255}$, et ita a dominicatu archiepiscopatus, usque, in presens alienavit.

Huic successit Rotbertus, vir nobilissimus, et potentissimus, [A p. 33] Ricardi primi ${ }^{256}$ filius. Hic vir magnę pietatis et honestatis fuit, et in mundialibus divitiis ${ }^{257}$ adeo ${ }^{258}$ laudatus, a secularibus ${ }^{259}$ viris. Sed carnis fragilitate superatus quamplures filios procreavit. Plura ætiam æcclesię bona fecit. Ecclesiam enim pręsentem miro opere, et magnitudine ædificare cępit. Ante obitum suum gratia Dei preveniente vitam suam correxit. Feminam enim reliqvit, et de hoc cęterisque pravis actibus suis penitentiam egit ${ }^{260}$. Et sic bono fine in quantum humana fragilitas capere potest ${ }^{261}$ quievit.

Rotberto successit Malgerus nepos eius; filius enim, Ricardi fratris sui fuit. Qui quia non electione meriti, sed carnali parentum amore, et adulatorum suffragio, in pueritia sedem adeptus est pontificalem, omni destitutus tutela. Potius adquievit carni, et sanguini, quam divinis mandatis. Voluptatem enim per omnia seqens ${ }^{262}$, ornamenta ecclesię cęteraque benefitia pueriliter erogavit. Et ideo auctore papa Leone, Willelmus dux Normannorum postea effectus ${ }^{263}$ rex Anglorum, asistente ${ }^{264}$ prefati papę legato, scilicet Hermenfrido Sedunensi episcopo,

248. vocabatur] vocatur BM.

249. regeret] rege- sup. lin. A.

250. ad] -d sup. lin. A.

251. cunctis] multis $\mathbf{M}$.

252. ignobilis] sed corr. ex innobilis al. man. A.

253. Dionisium] Dyonisium B Dionysium M.

254. Cavalcamp] Calvacamp B Calvacaput $\mathbf{M}$.

255. dedit] sup. lin. B.

256. primi] om. M.

257. divitiis] om. M.

258. adeo] -e- sup. lin. B.

259. secularibus] lac. inter -i- et -bus B.

260. egit] corr. ex fegit, f- del. A.

261. potest] sed corr. ex postest, -s- del. inter -o- et -t- A.

262. seqens] sec. -e- sup. lin. A. sequens BM.

263. effectus] -tus sup. lin. B.

264. asistente] assistente sed pri. -s- sup. lin. B. assistente M. 
cęterisque cumprovintialibus ${ }^{265}$ episcopis in Luxoviensi ${ }^{266}$ [B 6r] æcclesia ab episcopatu eum destituit. Deditque postea illi quandam ${ }^{267}$ insulam in Constantiniensi pago in mari sitam, in qua pluribus annis non quidem ut decuit vixit. Postæa vero, quo autem divino iuditio ignoratur, in mari submersus ${ }^{268}$ est.

Malgerio destituto elegit dux Willelmus quendam ${ }^{269}$ monachum nomine Maurilium; qui nobili prosapia ex Remensi pago ${ }^{270}$ exortus et in eiusdem civitatis æcclesia educatus. Inde ${ }^{271}$ in Leodicensi ${ }^{272}$ æcclesia omni ${ }^{273}$ liberalium artium peritia imbutus, Halverstitensis ${ }^{274}$ æcclesię scolasticus ${ }^{275}$ [A p. 34] effectus est qui locus in Saxonia ditissimus habetur, in quo pluribus annis honorifice vixit. Postea vero suscensus ${ }^{276}$ amore cęlestis patrię cuncta quę mundi sunt fastidiens, monasticam vitam appetiit. Sicque Fiscannense cęnobium ${ }^{277}$ adiens, monachus ibi effectus est in quo sanctę multo tempore vixit, cęterisque exemplum ${ }^{278}$ sanctitatis exibuit. Denique igne divini amoris exæstuans ${ }^{279}$, acriorem vitam eligens, licentia ab abbatę qui æcclesię preerat acepta ${ }^{280}$, Italiam petiit, eremique cultor solitariam vitam ducens, opere manuum vixit. Defuncto itaque abbate Florentinensis æcclesię quę in honore ${ }^{281}$ beatę Marię semper virginis constructa est, elegit eum marchio Bonefacius vir nobilis et potentissimus, et ita licet invitus, bonorum tamen virorum ammonitionibus superatus, abbas eiusdem loci ordinatus est, ubi multo tempore subditos pro posse suo sancte et regulariter ${ }^{282}$ rexit. Sed quia [B $6 \mathrm{v}$ ] vita iustorum est detrimentum pessimorum, monachi qui tempore predecessoris sui indisciplinate vixerant constantiam regulę patris Benedicti qua eos regulariter constrinxerat ferre nolentes, sed in omnibus bonis operibus sibi resistentes, detrimentum vitę ei machinati sunt. Et quia pluribus annis in hoc laborans nullo modo se in eis vidit proficere, saluti proprie prospitiens abbatiam deservit, et ad proprium locum scilicet Fiscannum rediit. In quo sancte usquequo in episcopatu intronizatus est vixit. Hic æcclesiam a Rotberto archiepiscopo ${ }^{283}$ inceptam complevit, et astante ${ }^{284}$ Guillelmo Normannorum duce, postea Anglorum rege cum omnibus suffraganeis suis,

265. cumprovintialibus] provincialibus $\mathbf{M}$.

266. Luxoviensi] Lexoviensi BM.

267. quandam] -n- sup. lin. al. man. A. quamdam M.

268. submersus] su(m)mersus vel su(b)mersus B summersus $\mathbf{M}$

269. quendam] quemdam $\mathbf{M}$.

270. pago] agro $\mathbf{M}$.

271. Inde] lac. inter inde et in A.

272. Leodicensi] Leodiensi M.

273. omni] omnium M.

274. Halverstitensis] -r-sup. lin. et lac. inter Hal- et -verstitensis A.

275. scolasticus] sed corr. ex scolaticus, -s- in al. man. scr. B. scholasticus M.

276. suscensus] succensus BM.

277. cęnobium] coenobium sed-e-sup. lin. B.

278. exemplum] corr. ex exemplo sed -o non del. et ù sup. lin. al. man. A.

279. exæstuans] -s- sup. lin. A.

280. acepta] accepta sed pri. -c- sup. lin. B.

281. in honore] in marg. A.

282. regulariter] sed corr. ex regulaliter A.

283. archiepiscopo] sed pri. -i- sup. lin. A.

284. astante] corr. ex adstante -d- del. A. 
concilium in Rotomagensi æcclesia de castitate conservanda, et [de] ${ }^{285}$ cęteris sanctorum [A p. 34] patrum institutionibus pastorum incuria neglegenter postpositis viriliter restituendis religiose cęlebravit. Postea perfecta æcclesia dedicavit eam astante Guillelmo Normanorum ${ }^{286}$ duce anno .MLXIII. ${ }^{287}$ Dominicę Incarnationis, regnante Henrico nobilissimo rege Francorum, astantibus etiam cumprovintialibus ${ }^{288}$ episcopis, scilicet Odone Baiocensi, Iohanne Abrincensi, Hugone Luxoviensi ${ }^{289}$, Guillelmo Ebroacensi, Ivone Sagiensi, Gaufrido Constantiniensi, cęterisque venerabilibus abbatibus, presidente etiam sedi apostolicę papa Victore ${ }^{290}$ secundo. Multa etiam bona de Christianę legis et æcclesisticę ${ }^{291}$ religionis restitutione fęcit, ieiuniis, et orationibus, et elemosinis ${ }^{292}$, [B $\left.7 \mathrm{r}\right]$ usque ad ultimum diem insistens, v idus Augusti animam Deo reddidit.

Defuncto venerabili antistite ${ }^{293}$ Maurilio, prefatus Guillelmus rex Anglorum Lanfrancum reverentissimum abbatem Cadomensis æcclesię, omnibus liberalibus artibus imbutum, sanctis moribus et operibus ornatum, quem postea Cantu[r]iensi ${ }^{294}$ æcclesię metropolitanum instituit ${ }^{295}$ episcopum, et primatem Anglorum ${ }^{296}$, Alexandro ${ }^{297}$ summo pontifici, et venerabili papę misit ${ }^{298}$, postulans eius clementiam, ut ei assensum preberet, quatinus eius ${ }^{299}$ auctoritate Iohannem Abrincatinę æcclesię episcopum, metropolitanę æcclesiæ pręficeret, eique ne aliqua occasione in hoc resisteret, litteris apostolicis mandaret. Ipse vero eius petitioni quia devotam vidit adquievit. Litteras inde pontifici misit, verba quę litterę continent hęc sunt: "Alexander episcopus servus servorum Dei, I. ${ }^{300}$, Abricensium venerabili episcopo, apostolicam benedictionem. Destituta Rotomagensi æcclesia pastore, conperimus ${ }^{301}$ Sedunensis episcopi, et Lanfranci abbatis relatione, te ex electione principis tui dilectissimi filii nostri Guillelmi regis Anglorum [A p. 36] ob vitę et morum probitatem, ad maiorem sedem promovendum, si ex auctoritate sedis apostolicę fuerit assensus, cui ${ }^{302}$ Deo auctore presidemus. Nos igitur moti illorum precibus ob salutem illius æcclesię, et omnium in tuis partibus volumus, atque dilectioni tuę apostolica auctoritate precipimus, ut quod

285. [de]] scr. sed del. A. om. BM.

286. Normanorum] Normannorum BM.

287. MLXIII] millesimo sexagesimo tertio sup. lin.B. millesimo sexagesimo tertio $\mathbf{M}$.

288. cumprovintialibus] comprovintialibus $\mathbf{M}$.

289. Luxoviensi] Lexoviensi BM.

290. Victore] -c- sup. lin. A.

291. æcclesisticę] æcclesiasticę B. ecclesiasticae M.

292. elemosinis] eleemosynis $\mathbf{M}$.

293. antistite] sec. -it- sup. lin. A.

294. Cantu[r]iensi] Cantiriensi BM.

295. instituit] in marg. A.

296. et primatem Anglorum] scr. sed del. et al. man. de s. xv misit scr. in lac. A.

297. Alexandro] -r- sup. lin. A.

298. misit] sup. lin. A.

299. eius] sup. lin. B.

300. I.] Ioh(ann)i sup. lin. B. Iohanni M.

301. conperimus] comperimus $\mathbf{M}$.

302. cui] sup. lin. A. 
divina dispensatio de te providit ${ }^{303}$, non contradicas, et electioni [B $\left.7 \mathrm{v}\right]$ te obedientem ${ }^{304}$ exibeas. Admonemus ${ }^{305}$ itaque fraternitatem dulcedinis tuę ut si in modico fuisti fidelis, in maiori bene operari non desinas, populum divini verbi pabulo reficias ${ }^{306}$, ut merearis audire illam benignam vocem Domini dicentis: 'Euge serve bone et fidelis, quia super pauca fuisti fidelis supra multa te constituam'. De cętero secretiorem animi nostri voluntatem, planius audies per nostrorum legatorum veridicam relationem".

Iohannes vero episcopus apostolica legatione recepta, et omnium conprovintialium ${ }^{307}$ episcoporum, cunctorumque ætiam eiusdem æcclesię canonicorum, electione cummuni ${ }^{308}$ consensu facta, metropolitanam adeptus est sedem. Hic vero fuit vir progenię nobilis, liberalibus imbutus disciplinis ${ }^{309}$. Is alias satis strenuus, animi fuit impatientissimus. Crudescebat in eo hic morbus, et ut ita dixerim exaggerabatur, tum carnis nobilitate, tum pręlationis dignitate. Solent enim hęc duo plerumque positos in culmine in fluxum ${ }^{310}$ usque superbie ipso potentie fastigio lenocinante corrumpere, adeo ut norme obliti iusticię ${ }^{311}$, unde animi sui furorem videntur pascere, hoc zelo iusticię velint deputare. Evenit autem aliquando, ut hi tales non pastores sed crudeles exactores occulto Dei iudicio coram ipsis quos iniuste vexaverunt corripiantur: quatinus exemplariter correpti, et posteris sibi similibus sint terrori, et parvulis spei. Quod totum in hoc de quo agitur Iohanne archiepiscopo divina censura exibuit, in eo quem is adversus sancti Audoeni cęnobitas inconsulte tumultum exercuit. Quod [B 8r] non derogatorie, non insultatorie, sed consultorie censuimus scribere. Primo, quia insolitum, incredibile, et quasi monstro simile, tantum tumultum, tantam turbam eo die sine sanguine accidisse. Secundo, ut loco nobilissimo et ab omni iure seu consuetudine $^{312}$ archipresulum huius urbis privilegio Karoli magni libero sit memoriale, quo se probent nec in magnis excessibus ipsorum aliquid iusticię debere.

Causa erat, qua Guillelmus Nortmannorum ${ }^{313}$ comes et Anglorum rex gloriosus, Cinomannis cum expeditione sua morabatur. Aderant ei inter reliquos proceres iste Iohannes sedis huius archiepiscopus, ut vir excellentis ingenii, et non mediocris consilii, Nicholaus ${ }^{314}$ quoque reverendus abbas supradicti cęnobii. Imminebat celeberrima, totisque votis excipienda sanctissimi Audoeni dies natalicia. Et quia moris est ut archiepiscopus ipsa die inibi missarum

\footnotetext{
303. providit] sup. lin. A.

304. obedientem] oboedientem B.

305. Admonemus] -d- sup. lin. al. man. A.

306. reficias] lac. inter pri. -i- et-c-, et sec. -i- sup. lin. A.

307. conprovintialium] comprovincialium $\mathbf{M}$.

308. cummuni] communi BM.

309. disciplinis] scr. sed del. et rescr. al. man. A.

310. fluxum] corr. ex flexum sed-e- non del. et u sup. lin. B.

311. iusticię] -ci-sup. lin. B.

312. consuetudine] consuedine $\mathbf{M}$.

313. Nortmannorum] -t-sup. lin. B.

314. Nicholaus] Nicolaus M.
} 
solennia ${ }^{315}$ celebret, non pro ulla quidem vel ipsius gentaculi ${ }^{316}$ vicissitudine, sed quasi in recompensationem consecrationis sue, quam non nisi in prefata ecclesia cuivis $^{317}$ sedis memorate licet accipere, missione a rege petita redibat concite, abbate prenominato interim ad occupatiora remanente. Quid plura? Adest dies veneranda, clerici maioris ęclesie, solito eo conveniunt. Et quia premisso nuncio venturum se mandaverat, solenne ${ }^{318}$ missarum interim differtur, post aliquandiu vero e communi consilio nequid tante diei subtraheretur, dum veniat iniciatur. Tanta vero morositate, tanta id factum est devotione, ut non mirum totis animis hostem humani generis ad hanc lęticiam turbandam exarsisse, qui maximo sibi lucro credidit accedere, sic illud veneno sue nequicie tempus inficere, quod interim sibi dolebat $[\mathrm{B} 8 \mathrm{v}]$ deperire.

Finito itaque Kyrrie ${ }^{319} \mathrm{cum}$ duobus rithmis, exacto Gloria in excelsis Deo, quod inceptum ab abbate Ricardo ${ }^{320}$ Sigiensi chorus celeberrime fuerat executus cum laudibus suis, id vero totum expendebatur in prestolationem archipresulis; ecce accurrit ut turbo ${ }^{321}$ tempestatis, omnem confundens illius gratiam celebritatis. Hic nanque 322 totam mentis indignationem animo concipiens quod non usquequaque fuisset expectatus, torvis oculis, ore furibundo cunctis maledixit, conversusque 323 ad ipsos monachos excommunicavit, ex auctoritate Dei et sua officium presens interdicens cessare fecit, abbatem ab altari evellens divini officium ministerii prohibuit. Meroris erat plenum et stuporis cernere, tante festum leticię, tot et tantas voces eam preconantes in subitum silentium obmutuisse. Ipse ad complendum se officium preparat, clericis suis ut a loco intercepto peragerent imperat. Nichil ${ }^{324}$ hic reticendum fore censemus, quod dum alteri parti favendo dissimulamus, alteri totum derogando imputare videamur. Verum, falsi astipulatione ${ }^{325}$ non indiget. Fratres etsi decorem sibi tanti sui gaudii preripi dolentes, pontificali tamen auctoritati cedunt, festivis se ornatibus exuunt, satis cum tumultu ecclesiam egrediuntur, huc quidam, pars illo, alii alio succedunt, invicem et ad suos super suo pudore merentes conqueruntur.

Cum subito quidam meroris impatiens, dubium quidem an ex ipsis vel eorum famulis, plus furoris, minus consilii, animo colligens, turrim properat, maius ęcclesię signum pulsat. Hinc forum ocior advolat, archiepiscopum sancti Audoeni glebam ad maiorem ecclesiam asportare velle proclamat. Prosiliunt omnes e domibus, alius gladium, hic bipennem, diversi quod primum [B 9r] manibus occurrerat arripiunt, ecclesiam cum furore irrumpunt. Quidam curiositate acti celata

\footnotetext{
315. solennia] solemnia $\mathbf{M}$

316. gentaculi] jentaculi $\mathbf{M}$.

317. cuivis] leg. cuius

318. solenne] solemne $\mathbf{M}$.

319. Kyrrie] Kyrie M.

320. Ricardo] sup. lin.B Richardo M.

321. turbo] -u-sup. lin. al. man. B.

322. nanque] nanque $\mathbf{M}$.

323. conversusque] -que sup. lin. al. man. B.

324. Nichil] Nihil $M$.

325. astipulatione] adstipulatione $\mathbf{M}$.
} 
monasterii conscendunt, quędam ex tabulatis auferunt, quid sic furens populus agere vellet rimantur. Plurimi eius intentionis erant, ut quia eis tante continuationem leticie interrupisset, nec sibi perficere liceret. Archiepiscopus circumcirca furentium se turmis appeti expavescens, plus tamen desuper imminentes metuens, ab altari ad valvas monasterii fugam arripuit, vix elapsus, infra ambitum earum ipsis prius clausis se recepit, undique circum se sedilia et formas aggerari fecit. Non nulli tamen partis ipsius arreptis candelabris, cereis, et perticis, in monachos efferati, sed ab eis non segniter excepti, pudet dicere, quam foedo exemplo res eo die debuit determinari.

Constitit satis ipso die meritum sancti omnibus affuisse, qui hinc sevientium manus comprimendo, hinc archiepiscopum cum suis eo periculo eximendo, tantum nefas non parvo cunctis miraculo potuit avertere. Nam tanta subito nubis caligo id spacium sanctuarii quo loculi sanctorum continebantur obtinuit, ut vix vel a curiosis oculorum acie corripi potuerit. Rei congruit miraculum. Quia enim sacre Scripture diversis in locis per nubem nunc delinquentium cecitas, nunc Domini protectio figuratur, iure hoc in ipsa nube portendebatur. ${ }^{326}$ Hinc nempe insensibiliter furentium nubilum velut fumus ascendens divine gratię serenum turbabat, hinc manum Domini reatu ipsorum ad feriendum provocatam sanctus Audoenus meritis suis protegendo continebat. Dicto nil subripit quod refragetur, tantum ratio ipsa a toto pendens suffragatur. Ipsi sane cuius [B 9v] pacientię sit altissimus redditor estimare licuisset, ni se in sua pertinatia continens a consideratione rationis animum revocasset. Sed animositatis eius immanitas non destitit eo usque, quo se invehens in se, irruit in se. Igitur vicecomes civitatis archiepiscopum sic circumventum ut audivit, veritus ne quid inconsultius adversus ipsum ageretur, et ipse post noxe argueretur, militarem manum cogit, regis bannum omnibus pretendit, suppetias accurrit, iam nil reluctantem, immo sibi pęnitus diffidentem periculo eximit.

Iis tumultuum dementiis exacta est dies tante celebritatis. Estimet qui valet que facies tunc fuerit curię cęlestis, quam indigne tulerit sui precellentissimi civis Audoeni sic confusam, sic foedatam, sic prereptam diem sue remunerationis. Estimet quid extiterit miserie, tantum patronum nil penitus in filis suis quod Domini faciem placaturus offerret, eo die accepisse. Nos ignorantes divini secretum consilii omittimus, de hominibus humana pensamus. In tanta multitudine discreta sexu, ętate, et ordine, non credimus defuisse, et qui mente carnali se minus nocuisse penituerint, dum nil medium quin tam speciali gaudio privati forent attenderint, ${ }^{327}$ et qui sanioris consilii peccatis suis eam turbam imputaverint, vota sua prerepta gemuerint, a suo patrono veniam suspirantes super suis actibus erubuerint ${ }^{328}$.

Fratres in crastinum de suis eligunt per quos abbati suo quod factum fuerat innotesceret, et regem super hoc suggesturus adiret. Sed archiepiscopi nuntius precesserat, invidiam omnem in monachos retorserat. Sic infecto negotio reditum

326. portendebatur] sed abbr. incer. B prætendebatur $\mathbf{M}$.

327. attenderint] adtenderint $\mathbf{M}$.

328. erubuerint] erubuerunt $\mathbf{M}$. 
est. Rex licet post ipsius archiepiscopi et quorundam ${ }^{329}$ aulicorum instinctu animo in monachos motus, [B 10r] rem tamen ex equo pensans, hinc immoderatam arrogantiam, hinc inconsultum tumultum iustis librationibus preponderat. Iubet igitur statim ecclesiam ab archiepiscopo reconciliari. Quod cum satis irato et reluctanti animo abnueret, rex Michaeli episcopo Abrincatensi loci reconciliationem iniunxit, pudorem vero suum in futuro vindictam ${ }^{330}$ pretendens dissimulavit. Quatuor igitur monachos loci quos et factionis auctores audierat totidem aliorum coenobiorum abbatibus commisit, quatinus et archiepiscopo satisfaceret, et illi in peregrinatione sua luerent, quod minus consulte peccassent.

Non multo post tamen et rationis consideratione et petitu abbatis ipsorum flexus in presentiam sui eos revocavit, et ecclesie reconciliatos reddidit. In his omnibus semper apud ipsum cautum extitit, ne quid sibi archiepiscopus quasi sub ecclesiastico vigore in causis huius ecclesie insolenter arrogaverit. Immo postquam ei gemino fratrum eorundem exilio satisfecit, rem in consilium ponit, concilium cogit, quod abbatiam suam irato et tumultuanti animo intrasset, quod totius turbe causa et materia extitisset, quod loci reconciliationem sibi denegasset, iudicio primatum suorum trecentas libras exegit. Delicti satis hac vindicta exsolvisset, si intime facti penituisset, Dominique pacientiam non neglegendam ${ }^{331}$ putasset. Sed animi rancorem nec tunc primum adversus sancti Audoeni coenobitas occeperat, et hoc modo potuit potius exaggerari, quam leniri. Trium annorum spatium evolutum erat, et semper repulsam sui dolore continuo secum corrodebat. Congruenti sane exemplo suspensus, velut evangelice illius ficulneę fructus. Unde sic quidam, "Expectata tribus, fruc[B 10v] tum non attulit annis".

Cum post id temporis redeunte eadem festivitate paucis ante mensibus paralisi percussus ${ }^{332}$, sed ab hac infirmitate iam respirans ad solennitatem ${ }^{333}$ venit, et quia per se missam celebrare non potuit, Gisleberto Ebroacensi episcopo vices suas commisit, ipse in medio cantorum specie precentoris stetit. Ut vero evangelium cepit legi, horribile dictu, sic ab intimis humoribus in secretiorem meatum profluentibus est subito angustiatus, ut raptim urina procurrens lineam usque super pellicialem ${ }^{334}$ indumentum omne infecerit, pavimentum etiam quo stabat perquam humectaverit. Hinc post fidelium oblationes cum amplius dissimulare non posset, ecclesiam egressus, pudore non oportet dici quantum et merore confusus ad sua reversus est.

Quod ut primum ad aures populi percrebuit, quis estimare, quis dicere suffecerit, in quas et quantas voces se derepente sparserit? Omnes tamen in commune Domini magnificentiam sanctique Audoeni meritum personabant; iure hunc ab integritate presentis leticie sic ignominiose repulsum, quam olim indigne nimis proturbaverat acclamabant. Nemo nobis succensere ${ }^{335}$ habet si vera dicimus, quia

\footnotetext{
329. quorundam] quorumdam $\mathbf{M}$.

330. vindictam] vindicta $\mathbf{M}$.

331. neglegendam] negligendam $\mathbf{M}$.

332. paralisi percussus] paralysi perculsus $\mathbf{M}$.

333. solennitatem] solemnitatem $\mathbf{M}$.

334. super pellicialem] superpellicialem $\mathbf{M}$.

335. succensere] succencere $\mathbf{M}$.
} 
nemini examen iudicis omnium in cuius manus horrendum est incidere improperandum scimus, et ex aliena culpa poenam incurrere valde formidamus. Sed enim iudicia Domini que velut abissus ${ }^{336}$ multa sunt mirari, ipsum in tam sancto viro predicare, quo affectu pietatis isdem devote sibi famulantes protegendo semper foveat, plus est sacrilegii ingrato silentio tegere, quam ut dicatur reverentię. Cęterum non parum intentionem piam dirigit, studendum continue Domino servire in timore, et exul[B 11r] tare ei, sed eum ${ }^{337}$ tremore. Sobrie pensare, quam nitidum templum ipsi nosmet scilicet exibere deceat, si adeo zelans huius exterioris cultus in invisibilibus templis appareat. Non enim inhabitantes propter locum, sed propter inhabitantes locum Dominus elegit.

Verum ut coepta prosequamur, per alios tres annos adeo ipso 338 incommodo laboravit ut neque iam administrationis infulis deservire potuerit. Cum tandem regia auctoritate inmo ${ }^{339}$ consultu omnium pulsatus, episcopatu cedit, et ad quandam sui patrimonii villam sancti Philiberti dictam se cedit ${ }^{340}$, ubi et aliquantisper supervixit. Duodecimo vero sui presulatus anno viam universe carnis ingressus, hominem exiuit ${ }^{341}$. Inde tamen ad propriam sedem refertur et honorifice in ipsa, ecclesia tumulatur, $v$ Idus Septembris.

[S] uccessit huic imo ${ }^{342}$ processit $^{343}$, nam duobus ante obitum eius mensibus intronizatus est domnus Guillermus cenobii Cadomensis abbas, cum apostolica auctoritate, tum regio munere, tum denique communi electione. Vir sane et generis nobilitate cluens, et morum prerogativa prepollens.

\section{Translation}

\section{[The acts of the archbishops of Rouen]}

There are eighteen provinces of Gaul, one of which is called the Second Lyons, and in which is the noble and great city called Rodomus or Rouen ${ }^{344}$, on the river Seine. The church of this city is consecrated in honour of the blessed and glorious mother of God, the always-virgin Mary. It is a metropolis, which comprises six episcopal cities, the first being the city of Bayeux, the second Avranches, the third Evatinorum, which is called Évreux, the fourth Salanum, which is called Sées, the fifth Lisieux and the sixth Coutances ${ }^{345}$.

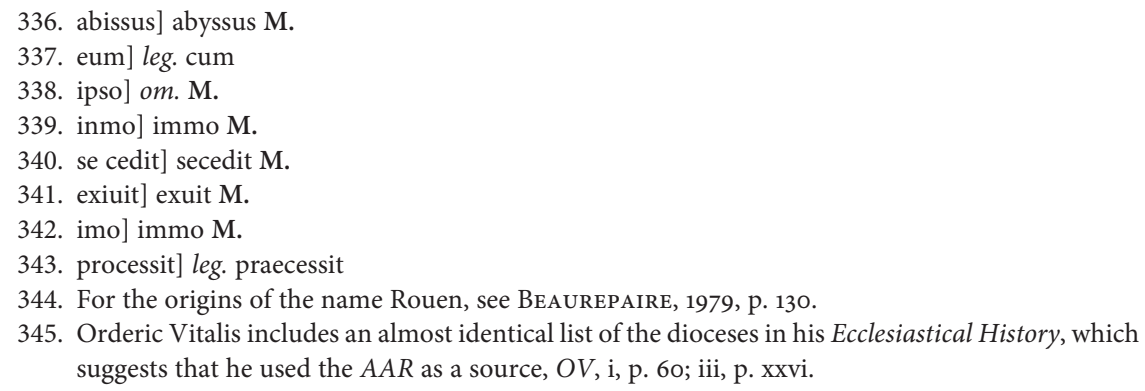


In this city of Rouen the excellent Mallonus ranked first ${ }^{346}$. Some people may be disturbed to read these words here, not observing that there is nothing contrary to their wish, namely that the most blessed Nicasius ranked as the first bishop of this city, which is not disputed here, if it were supported by a well worked statement. Therefore, let both clerics and monks pay attention so as not to go astray, however acutely they investigate the Scriptures, and let them decide that both these things can stand unopposed to each other. It is rightly said that Mallonus was first in the seat of Rouen, for no other preceded him with regards to the use and enjoyment of the archbishopric. Nor those who proclaim that blessed Nicasius was the first archbishop of this same seat are entirely wrong, for I think that there are many who know he was ordained in Rome by the blessed Pope Clement as the bishop of the city of Rouen, which until then had never been controlled by a pastor. Nor is it frivolous, but well founded and certain, exactly as his passion testifies, that united with St. Denis, and with the permission of Pope Clement, he came to the shores of Gaul. And before being able to reach his seat, which, as we said, he received in Rome, he suffered martyrdom, having his head cut off close to the borders of Normandy, along with Quirinus and Scubiculus ${ }^{347}$. Thus, of Nicasius or Mallonus, it is true to say, but in a different sense, that both were the first bishop of Rouen: Nicasius for the ordination, Mallonus for inhabiting the place. It may be said, therefore, that Nicasius was the first to be ordained bishop of Rouen, but Mallonus was the first placed on the seat. This does not contradict the following verse:

The excellent Mallonus ranked first,

Of honourable manners and from a famous family.

He shone by his words and stood out for his beneficial acts,

Lavish on any occasion, lenient and generous to the poor.

He looked after the weak spirited with sacred doctrine,

And purged those tormented by an evil spirit with sacred power.

Always taking care of his people, a pious and attentive pastor,

Before those entrusted to him, he made himself a wall against the enemy.

Sympathetic to the sick, he strengthened the crushed.

He magnified God by always offering Him the divine sacrifice,

Asking eternal peace and safety.

He took care of everyone with kindness, like dear brothers,

He was humble, moderate and full of reserve.

Free from baseness, he shone with the brilliance of his virtues.

He died on 23 October $^{348}$.

346. The terminus ad quem for Mallonus' episcopate is the appearance of his successor Avidiamus at the council of Arles in 314, "Liste des Archevêques...", in La cathédrale de Rouen..., 1996, p. 275, for which see all the archiepiscopal dates given in these notes.

347. For these two martyrs of the Vexin, see the passion of St. Nicasius in "Appendix ad catalogum codicum hagiographicorum civitatis Namurcensis”, Analecta Bollandiana, 1, 1882, p. 628-632.

348. The dating of Mallonus' death in both versions of the Acta archiepiscoporum as X kalendas novembris (23 October) demonstrates that, while his feast day was later celebrated on 22 October, this was obviously not the case in the eleventh century, VIOLETTE, 1997b, p. 357. 
Avidianus, who ruled the church under Pope Sylvester and Emperor Constantine, succeeded the blessed Mallonus ${ }^{349}$. He was a careful and diligent pastor for his people, who took part with Maternus, bishop of Cologne ${ }^{350}$, in the first council of Arles, which took place at the time of the synod of Nicea, as is found in the canons ${ }^{351}$. This blessed pontiff was an honest spirit, irreproachable in manners, and attentive to the salvation of the souls with which he was charged. To this succeeded Severus, and Severus by Eusebius, Eusebius by Marcellinus, Marcellinus by Peter ${ }^{352}$, and Peter by Victricius ${ }^{353}$.

He was brought up at the royal court with the blessed Pope Innocent ${ }^{354}$, as is found in a letter sent from this pope to him about preserving chastity, and other rules of the Christian religion. Indeed, it said among other things: "moreover, some of our brothers often seek to make curiales, or those occupied in public office, into clerks. But later they suffer more sorrow, when some order is made by the emperor to recall them, than they had joy in enlisting them. May the anxiety and sadness of our brothers, which we have frequently brought before the emperor when appealing earlier on their behalf, at least be an example. You yourself have become aware with us of these circumstances, and the great displeasure that was pressing not only those clerks of lower rank from the curiales to return, but also those appointed to the priesthood" ${ }^{355}$. He was in fact a most glorious pastor, inflexible in pursuing the crimes of his people, a most gentle father towards widows and orphans, merciful to the poor, and sympathetic to all the disabled and the sick ${ }^{356}$.

Innocent succeeded him, and he was succeeded by St. Evodus, Evodus by Sylvester, Sylvester by Malsonus, Malsonus by Germanus, Germanus by Crescentius $^{357}$, and Crescentius by the blessed Gildardus, brother of St. Medardus ${ }^{358}$, whose life the blessed Fortunatus wrote in splendid verses ${ }^{359}$. They were born the same day, were ordained the same day and both returned to Christ the same day.

Blessed Flavius ${ }^{360}$ succeeded Gildardus, during whose pontificate was constructed, in a suburb of the city of Rouen, the church in honour of St. Peter the Apostle ${ }^{361}$, nobly built, in the first year of the reign of King Clothar of the

349. We can say no more than Avidiamus was bishop in 314.

350. Maternus II, bishop of Cologne (c. 285-315).

351. For the proceedings of the council of Arles see MANSI, 1757-1798, ii, cols. 463-513.

352. Of these four prelates we can say no more than Eusebius was bishop in 346

353. Victor (386-c.404).

354. Innocent I (401-417)

355. The full text of this letter can be found in Migne, PL, 1844-1864, xx, cols. 469-481; lvi, cols. 519-527.

356. It was also during Victricius' pontificate that the primitive cathedral was completed, LE MAHO, 1991, p. 7-19. Victricius was also a correspondent of St. Paulinus of Nola (MigNe, PL, 1844-1864, lxi, cols. 237-243, 353-357), and was the author of the sermon De laude sanctorum, Herval, 1966, p. 109-153.

357. Of these five prelates we can say no more than that Germanus was bishop in 461 .

358. St. Medardus, bishop of Noyon (530-545).

359. Venantius Fortunatus, Vita sancti Medardi episcopi Noviomensis et Tornacensis, in Migne, PL, 1844-1864, lxxxviii, cols. 533-540.

360. Flavius (538-541).

361. I.e. Saint-Ouen de Rouen. 
Franks ${ }^{362}$, and in which the body of St. Ouen, his successor, was carried in burial. This blessed Flavius was imbued with multiple virtues, ignited by divine love and generous to the poor, he ruled the church of Rouen in the year of our Lord $500^{363}$.

To this succeeded Pretextatus, a man of great holiness and an enemy to all injustice $^{364}$. He was archbishop at the time of King Chilperic ${ }^{365}$, son of Clothar, a man of excessive cruelty who was ignited, along with his impious wife Fredegund ${ }^{366}$, by unlimited hatred against the pontiff. This hatred had no other origin except that Pretextatus loved Chilperic's brother King Sigebert ${ }^{367}$, whom Chilperic had killed treacherously, and that he had the same love for Sigebert's son Childebert ${ }^{368}$, and his mother Brunhilda ${ }^{369}$. Irritated by this, Chilperic charged Pretextatus of a crime, namely that the bishop had hidden a great part of the treasure of the king's brother Sigebert, and that when Chilperic's nephew Childebert had entered into conflict against him, the bishop had given it to Childebert. For this reason he persecuted him, expelled him destitute from the episcopate, and exiled him to a certain island in the pagus of Coutances ${ }^{370}$, located in the open sea, and in his place he ordained the archdeacon Melantius archbishop ${ }^{371}$.

Here is how he expelled him. The king convened in council his bishops, among whom was Gregory, archbishop of Tours, a man of great authority and integrity ${ }^{372}$. He neither gave his approval to this crafty trick, by which a bishop was deceived, nor to his unjust dismissal. The king, with a certain impious audacity, let Pretextatus know through certain bishops that if he acknowledged what had been exposed to the council, and if he were to publicly proclaim it prostrate before the king, all would be forgiven. Deceived by the exhortation of impious bishops, he acquiesced to the misleading suggestions of the king. Then the king began to exclaim: "You have heard he is associated with this crime, and now on that lay down a sure sentence". And thus they deposed him, and the king ordered that he be removed in exile. After the death of the king, with Queen Fredegund unwilling, all the primates and their suffragans, with debate and judgement, called him back to his church, and Melantius was deposed and

362. Clothar I (511-561).

363. The date of 500 for Flavius' pontificate is obviously incorrect, and comes from the Vita Audoeni II (BHL no. 751), which the author of the AAR used to compose his entry on Flavius. It too mentions the building of the church of St. Peter, and the translation of the body of St. Ouen to this church, VioletTe, 1997b, p. 356.

364. Pretextatus, (567-577 and 584-586).

365. Chilperic I, king of Soissons (561-584).

366. Fredegund, queen consort (d. 597).

367. Sigebert I, king of Metz (561-575).

368. Childebert II, king of Austrasia and Burgundy (575-595).

369. Brunhilda (545-613).

370. The island was probably Jersey, KRUSCH, 1937, p. 223 n. 4.

371. Melantius (577-584 and 586-601).

372. Gregory, archbishop of Tours (573-c. 594). 
Pretextatus established in his own seat ${ }^{373}$. Yet Melantius remained close to the most impious Queen Fredegund, who never liked the blessed Pretextatus and tried to obstruct him. Along with the aforesaid Melantius, therefore, she tainted certain minds with a reward, and as Gregory of Tours recounts in his writings, during the night of Holy Passover, in the pontifical place, where Pretextatus usually stood, they struck him with swords and killed him. As soon as he felt the wounds he ran to the altar and embraced it, and, fortifying himself with the sacrament of the body and blood of the Lord, he returned his soul to God. All the princes of the land honourably delivered his body to burial with great cries and lamentations about the abandonment of so great a pastor and protector. Afterwards Melantius, who during the time of Pretextatus' exile had usurped the episcopate, was placed on the same seat through the counsel and scheming of the above said queen ${ }^{374}$.

To this succeeded the prelate Hidulfus, a man prudent and honest ${ }^{375}$. Hidulfus was succeeded by the blessed Romanus, of noble origin and famous for his virtue. The blessed Romanus was succeeded by the celebrated St. Ouen, of illustrious birth and excellent virtue. Saint Ouen was succeeded by Ansbertus, a worthy prelate, and glorious through his holy works. We have only alluded to the memory of these three and blessed Gildardus ${ }^{376}$, because we have their deeds in the splendidly composed works of trustworthy men ${ }^{377}$.

The venerable Grippo succeeded Ansbertus. Grippo was succeeded by Ranilandus, a man worthy and honest. Ranilandus was succeeded by St. Hugh, who had an honourable life and was of great honesty, as his vita testifies ${ }^{378}$. Hugh was succeeded by Ratbert, a man prudent and diligent, and Ratbert by Grimo ${ }^{379}$. He was a man of great nobility and integrity, and he governed his people in an exemplary way as much by the example of his good works, but even better by his sermons. He increased the goods of the church of Holy Mary Mother of God, the seat over which he presided, with his own goods and several other benefices. Indeed, he donated Fontaine, on the river Iton, with all its dependences ${ }^{380}$. Grimo was succeeded by Rainfredus ${ }^{381}$, a man of a noble family and imbued in

373. Melantius (577-584 and 586-601).

374. For discussion of this entry, see Violette, 1997b, p. 359-362.

375. We can say no more than Hidulfus was bishop in 614 .

376. For the life of Gildardus, see PonCELET, 1889, p. 389-406.

377. Romanus (631-641), Ouen (641-684) and Ansbertus (684-687). The scholarship on Ouen is extensive. A good general introduction is VACANDARD, 1902. For Romanus, and the dossier of texts dedicated to him, see Lifshitz, 1988, p. 160-433. For Ansbertus, who was actually more revered at the abbey of Saint-Wandrille than at Rouen, see Lifshitz, 1995a, p. 39-56 and Lifshitz, 1995b, p. $185-186$.

378. It is unknown whether this is the Vita Hugonis, of poor quality and produced at Jumièges (VAN Der Straeten, 1969, p. 215-260), or the Gesta Hugonis (AASS, 9 April, I, p. 844-846), of better quality and written at Saint-Wandrille.

379. Of these five prelates we only know the pontificates of Grippo (696-697), Hugh (723-730) and Grimo (after 744-748).

380. Most likely in the vicinity of Hondouville, Eure, cant. Louviers.

381. Rainfredus (748). 
the study of letters, who increased the goods of the church through his own benefices. He in fact gave a vill in the Vexin, which is called Cramoisy, and he acquired from noble men very many benefices for the work of his church ${ }^{382}$.

Remigius, of blessed memory, succeeded Rainfredus ${ }^{383}$. He was the son of Charles ${ }^{384}$, who was called mayor of the palace, and brother of Carloman ${ }^{385}$, who after giving up his share of the kingdom, became a monk at Mount Soracte, where he built a church in honour of St. Sylvester, and from where he left for the monastery of Saint Benedict in Monte Cassino. The same Remigius was also the brother of Pippin ${ }^{386}$, who was consecrated king by Pope Stephen ${ }^{387}$. This Pippin, on the pleas of his brother, the monk Carloman, entrusted to Archbishop Remigius the mission of going to the place known as Fleury, so that he might return to the legates of Carloman the body of St. Benedict, which was resting there ${ }^{388}$. And when he arrived there, he called on the abbot then ruling the monastery, who was called Medo ${ }^{389}$, and announcing the decision of the king, he entered the church with the legates of Carloman. As they approached the tomb of the saint they were suddenly struck by blindness. Shaken with great terror, they lay prostrate in front of the aforesaid abbot and the brothers of the place, entreating them to beg the Lord for mercy, so that he might grant it to them. The blessed Remigius promised that never again would he move the body of the saint. What more? At once they heard clearly, and Remigius and his companions recovered their former health. However, he requested that the aforesaid abbot might show him the relics of the blessed man, lest the place where Benedict had faithfully served God lose such great protection: this was granted willingly. And thus the legates returned to their own home, and blessed Remigius to his. He acquired many benefits for his church, and he granted much from his own property. This very noble man was always watchful over the flock that was entrusted to him, and he also shone by his manners and works, and he had a pious end.

The blessed Remigius was succeeded by the venerable pontiff Mainardus, and Mainardus by Guillebertus, who directed the church appropriately and with honour at the time of the emperor Charles the Great ${ }^{390}$. Guillebertus was

382. Cramoisy (Oise, cant. Montataire) is not in the Vexin, but the Beauvaisis. This benefice is cited in the charter of Charles the Bald, which confirmed the goods of the cathedral at the time of Bishop Riculfus, Tessier, 1952, ii, $n^{\circ}$. 399. It was confirmed by Duke Robert I in $1028 \times 1033$, FAuroux, $1961, \mathrm{n}^{\circ} .66$.

383. Remigius (755-762).

384. Charles Martel (719-741).

385. Carloman, mayor of the palace (along with Pippin III) (741-747). He died in 754.

386. Pippin III (741-768).

387. Pope Stephen II (752-757). The consecration took place in 754, KuRZE, 1895, p. 12.

388. This story can be found in a vita of Remigius (BHL no. 7174), in a thirteenth-century collection of saints' lives belonging to the abbey of Saint-Ouen (Bibl. mun. Rouen, ms U 64 Omont 1411, fol. 63v-65r), and in the Miracula sancti Benedicti by Adrevaldus of Fleury, Certain, 1858, p. 34-42. It is most likely that the cathedral author relied upon the last of these, VIOLETTE, 1997b, p. 363.

389. Medo, abbot of Fleury-Saint-Benoît (738-759). For his career, see CHENESSEAU, 1931, p. 11-12, 67.

390. Archbishop Guillebertus actually served during the reign of Louis the Pious (814-840), and is mentioned in a capitulary of 825 as missus dominicus, Duchesne, 1907-1915, ii, p. 209. 
succeeded by Rainowardus, worthy of the position of pontiff. Rainowardus was succeeded by Gunbaldus, of a noble family and celebrated for the frequency of his good works. Gunbaldus was succeeded by Paul, a prelate gentle and most prudent. Paul was succeeded by Wanilo, a bishop devoted to God and most reverent in all things. Wanilo was succeeded by Adalardus, the nephew of Archbishop Gunbaldus, who was very religious in all deeds ${ }^{391}$. Adalardus was succeeded by Riculfus, a noble man, and rich in many estates, which he bequeathed to the church that was entrusted to him. He was archbishop in the time of King Charles, father of King Louis, whose son was King Lothar. It was in his time that the descendents of Charles the Great were driven from the throne ${ }^{392}$, for Duke Hugh, called the Great ${ }^{393}$, usurped the throne and was consecrated king, and was succeeded by his son Robert, a king devoted to God ${ }^{394}$. Riculfus had the king confirm the charters of the church by royal decree ${ }^{395}$. Riculfus was succeeded by John, a devout and religious prelate. John was succeeded by Guy, an honourable man and a most reverent pastor ${ }^{396}$.

Guy was succeeded by Franco, a prudent pontiff and of an invaluable help to his people ${ }^{397}$. During his time, Rollo, leader of the Danes, invaded the country which was being called Francia, but which, marked by their name, is now Normandy. And Franco soothed Rollo's savage mind, as much by divine words as by pious deeds, in order that he could rule the land he had acquired with peace and justice. Afterwards, introduced by the preaching of the aforesaid pontiff to Christian law, Rollo was baptised by him, and persevering in the catholic faith, he went to Christ by a pious end ${ }^{398}$. Then Franco was succeeded by Gunhardus, a man wise and provident in everything ${ }^{399}$. Then Gunhardus was succeeded by Hugh, from a famous family but unworthy in many deeds. He was, in fact, a monk at Saint-Denis when William, son of Rollo, duke of the Normans ${ }^{400}$, made him bishop, but after having put aside the obligations of the Holy Rule, he gave himself over entirely to desires of the flesh. He had very many sons, and

391. Mainardus (c. 772), Guillebertus (c. 818), Rainowardus (c. 828), Gunbaldus (c. 843), Paul (849) and Wanilo (c. 858).

392. The author is confused at this point, and places the episcopate of Riculfus (874) during the reign of Charles the Simple (898-922), rather than Charles the Bald (843-879). This error is also found in the Annals of Rouen, which the author of the AAR must have used, ViOLETTE, 1997a, p. 119.

393. Hugh Capet (987-996).

394. Robert the Pious (996-1031).

395. See Tessier, 1952, ii, $\mathrm{n}^{\circ} .399$.

396. John (c. 876) and Guy (c. 892)

397. Franco (c. 911-919)

398. Here the author echoes the statement by Dudo of Saint-Quentin that Franco was the baptiser of Rollo, Dudo of Saint-Quentin, De moribus..., p. 170. Olivier Guillot, however, has argued that it was Archbishop Guy, Franco's predecessor, who was actually the baptiser of Rollo, and that Franco was simply used by Dudo to symbolise the privileged relationship enjoyed by Rollo with the Franks, Guillot, 1981, p. 200-202.

399. Gunhardus (c. 920-942).

400. William Longsword, duke of Normandy (927-942). 
destroyed the church and its goods ${ }^{401}$. Indeed, he gave Tosny ${ }^{402}$, which was in the archbishop's demesne, with all its dependences, to his brother Ralph, a most powerful man, son of Hugh de Calvacamp, and thus this benefice remains alienated from the archbishop's demesne until this day ${ }^{403}$.

He was succeeded by Robert ${ }^{404}$, a man most noble and powerful, the son of Richard the first ${ }^{405}$. This man was of great piety and honesty, and was much admired among laymen for his wealth, but he was overcome by the weakness of the flesh and had very many sons ${ }^{406}$. Still, he did good things for his church. He in fact began the present church with massive construction and remarkable works ${ }^{407}$. Before his death, by the grace of God, he corrected his life. He left his wife, and for this and other perverse acts he repented; and thus, thanks to a pious end, in so much as human fragility can redeem itself, he rests in peace.

Robert was succeeded by his nephew Mauger, who was the son of his brother Richard ${ }^{408}$. It was not the distinction of his merit, but the love of his parents and the support of sycophants that raised him to the episcopal see as a young boy. Following pleasure through everything, in fact, he childishly distributed the ornaments of the church and other benefices. This is why, William, duke of the Normans, later king of the English ${ }^{409}$, with the authority of Pope Leo ${ }^{410}$, and in the presence of the papal legate Ermenfrid, bishop of Sion ${ }^{411}$, and the other bishops of the province, relieved him of the episcopate in the church of Lisieux. And afterwards he gave to him a certain island in the pagus of Coutances, located in the sea, on which he lived, not that it is fitting, for many years. After which, although one does not know by what divine judgement, he drowned in the sea ${ }^{412}$.

401. This negative view of Archbishop Hugh (942-c. 989) has had a lasting effect. Orderic Vitalis wrote that "he received no praise from any of the writers who have described him" and that "he was a monk in dress but not in deed", while the Metrical chronicle also confirms that he was regarded as anathema: "Hugh followed, violator of God's law | Worthy enough by birth, but blind to Christ", OV, iii, p. 80-82. Felice Lifshitz sought to revive his standing (Lifshitz, 1998, p. 505-524), and while he certainly seems to have played an important role in the governance of the duchy, it is possible his close cooperation with King Louis IV d'Outremer, who occupied Rouen during the minority of Richard I, may account for Hugh's negative reputation, Le МАHO, 2001, p. 15-16, 28-29.

402. Tosny, Eure, cant. Gaillon.

403. See Musset, 1977, p. 48-49.

404. Robert (c. 989-1037).

405. Richard I, duke of Normandy (942-996).

406. Archbishop Robert had three sons, one of whom (Richard) inherited the comté of Évreux from him. For Robert's secular activities while archbishop, see BAUDUIN, 2004, p. 325-330.

407. Controversy remains over the archbishop's exact role in the building of his cathedral. For discussion, see BAYLÉ, 1995, p. 153-158.

408. Mauger (1037-1055) was the son of Richard II, duke of Normandy (996-1026).

409. William the Conqueror, duke of Normandy (1035-1087) and king of England (1066-1087).

410. Leo IX (1049-54).

411. Ermenfrid, bishop of Sion and papal legate $(1054 \times 1055$-c.1088).

412. The island was Guernsey, where, according to Wace, he lived with his woman Gisla and fathered many children, the most notable of whom was Michael of Baynes, who later became a knight of Henry I. He fell out of the boat he was in as it made harbour at Wincant (an unidentified port on the Cotentin), and his body was taken to Cherbourg for burial, Wace, Roman de Rou, BurGESS, 2002, lines 4541-4618. 
With Mauger abandoned, Duke William selected a certain monk, named Maurilius. He came from a noble family from the pagus of Reims, and was trained in the church of that city. He was then imbued with the knowledge of all the liberal arts in the church at Liège, and then became scholasticus at the church of Halberstadt, the richest place in Saxony, where he lived honourably for many years. After which, ignited by love of the celestial homeland, and tiring of the riches of the world, he wished to embrace the monastic life. And thus, visiting the monastery of Fécamp, he there became a monk, where he lived holily for a long time, and gave various examples of holiness to all the others ${ }^{413}$. Then, burning with the fire of divine love, he chose a harder life, and with the agreement of the abbot who directed the church ${ }^{414}$, he made for Italy, where he carried out a solitary life in the wilderness and lived off the work of his hands ${ }^{415}$. With the death of the abbot of the church of Florence ${ }^{416}$, which was constructed in honour of the blessed always-virgin Mary, the marquis Boniface, a noble and most powerful man, selected him ${ }^{417}$. And although reluctant, Maurilius was overcome by the admonitions of good men, and was ordained abbot of this place, where for a long time he directed his subordinates holily and in accordance with the rule. But because the life of the just is a detriment to the wicked ${ }^{418}$, the monks, who had lived without discipline during the time of his predecessor, did not want to endure the rigour of the rule of father Benedict to which he forced them, and resisting his good initiatives, plotted an attack against his life ${ }^{419}$. And because he worked there for many years and had not seen them progressing in any way, having his own safety in mind, he left the abbey and returned to an appropriate place, namely Fécamp, where he lived devoutly until he was established in the bishopric ${ }^{420}$. He completed the church started by Archbishop Robert, and, in the presence of William, duke of the Normans, later king of the English, and with all his suffragans, he reverently celebrated a council in the church of Rouen so that chastity was observed, and that other instructions of the Saintly Fathers, neglected heedlessly by the carelessness of pastors, were firmly restored. Afterwards, the completed church was dedicated in the presence of William, duke of the Normans, in the year of our Lord 1063, during the reign of Henry, most noble king of the Franks, and in the presence of the bishops of the province, namely, Odo of Bayeux, John of Avranches, Hugh of Lisieux, William of Évreux, Ivo of Sées, Geoffrey of Coutances and other

413. Maurilius made his first visit to Fécamp sometime in the 1030s, BoüARD, 1959b, p. 82

414. The abbot was John of Ravenna (1028-1078).

415. Maurilius most likely lived as a hermit in either Fonte Avellana, San Vincenzo, near the confluence of the Furlo and Metauro, or at San Salvatore, near Bibbiena, BoüARD, 1959b, p. 83 .

416. Maurilius' predecessor was probably Albizo, who replaced Abbot Peter (fl. 1038). For discussion, see BOÜARD, 1959b, p. 84-85.

417. Boniface III, marquis of Tuscany (1027-1052).

418. Cf. "sic bonorum vita detrimentum est pessimorum", "De Joseph...", in Divi Ioannis Chrysostomi..., p. 427

419. Orderic informs us that he found a poisoned cup prepared for him, $O V$, iii, p. 88.

420. Maurilius returned to Fécamp at an unknown time in the 1050s, BoÜARD, 1959b, p. 85. 
worthy abbots ${ }^{421}$; Pope Victor II being in the pontifical see. He made many benefits for the re-establishment of the Christian law and religious rites of the Church ${ }^{422}$. He dedicated himself to fasting, sermons and alms giving until the end of his days, and on 9 August his soul returned to God.

With the death of the venerable bishop Maurilius, William, king of the English, sent Lanfranc, the very reverend abbot of Caen ${ }^{423}$, imbued in all the liberal arts, a saint by manners and deeds, who was afterwards established as archbishop of Canterbury and primate of the English, to the supreme pontiff, the worthy Pope Alexander ${ }^{424}$. There he asked mercy of him, as well as that he might offer approval, in so far as that, by his authority, John, bishop of the church of Avranches, might be put in charge of the metropolitan church ${ }^{425}$, and that he send apostolic letters, in order that John might not by some pretext resist. The pope acquiesced to this proposal, as he saw it was devout. He thereupon sent his pontifical letters, of which the words are here: "Bishop Alexander, servant of the servants of God, to J., worthy bishop of Avranches, apostolic blessing. We learned, by the report of the bishop of Sion and Abbot Lanfranc that, with the church of Rouen being deprived of a pastor, our most dear son William, king of the English, your prince, had promoted you in consideration of your integrity and your morality to this vacant seat, provided that you have the assent of the apostolic see, which by the authority of God we occupy. This is why, with regard to their supplications, and desiring to contribute to the blessings of this church and all those of your country, we wish and command on your charity, in accordance with apostolic authority, that you do not resist that which divine will has provided, and that you show yourself obedient by accepting your election. We therefore remind the fraternity of your kindness, in the hope that, since you have been faithful in your moderate role, you will not cease doing good in this large one, and will nourish your people with the food of the divine word, so that one day you may merit hearing the gentle words of the Lord: 'Well done, good and faithful servant, you have been faithful with a few things; I will put you in charge of many things' ${ }^{426}$. As for the remainder, our legates will inform you truly of our feelings and our more secret intentions".

Thus John received the apostolic legation, and with the mutual agreement of all the bishops of the province and the canons of this same church, gained the metropolitan seat ${ }^{427}$. He was of noble lineage and knowledgeable in the

421. Odo, bishop of Bayeux (c. 1049-1097), John, bishop of Avranches (1060-1067), Hugh of Lisieux (1049-1077), William, bishop of Évreux (1046-1066), Ivo, bishop of Sées (c. 1035-c. 1070), and Geoffrey, bishop of Coutances (1049-1093).

422. It is possible that an eleventh-/twelfth-century marginal note in the cathedral $A A R$, which reads Mihi autem, refers to the Introit antiphon of the same name, and is evidence that Maurilius was remembered within the cathedral community for having restored this particular rite.

423. Lanfranc, abbot of Caen (1066-1070), and archbishop of Canterbury (1070-1089).

424. Alexander II (1061-1073).

425. John (1067-1079).

426. Matthew 25:21.

427. The date of John's official translation to the archiepiscopal seat is unclear. For discussion, see VACANDARD, 1893, p. 117 n. 1. 
liberal arts. He was otherwise sufficiently active, but of a most impatient mind. This evil worsened, and it developed, so to speak, as much because of the nobility of his blood as the dignity of his prelacy. These two reasons have in fact regularly perverted those who are placed at the top with a flux of pride, the very height of power pandering to $i^{428}$, and thus forgetting the rule of justice, they pretend to ascribe their love of justice that which feeds in them, it seems, the madness of their hearts. However, it happens sometimes that such characters, who are not pastors but cruel supervisors ${ }^{429}$, are corrected by the secret judgement of God in front of those they wrongfully tormented. Thus corrected in an exemplary way, they are for those who would act similarly in the future an object of dread and for the humble an object of hope. Divine providence showed all that in the person of Archbishop John, of whom we are speaking, when, in the presence of the monks of Saint-Ouen, he inconsiderately provoked a commotion. What we have decided to write down is not in order to derogate, nor to insult, but as constructive criticism. First, because it is strange, incredible, and, so to speak, like an omen, that such a tumult, such an agitation, occurred on that day without bloodshed. Second, so that it might, for this most noble place, which through a charter of Charles the Great is free from the rights and customs of the archbishops of this city, be a record with which the monks might prove that they are bound in no way to their jurisdiction, even in the greatest extremes ${ }^{430}$.

The cause of this business was that William, glorious count of the Normans and king of the English, was delayed at Le Mans with his expedition. Archbishop John, a distinguished man of wise counsel, and Nicholas, worthy abbot of the above-mentioned monastery, were among the remaining nobles helping him ${ }^{431}$. The most celebrated anniversary of the death of the most venerated saint Ouen was imminent, and was being welcomed with prayers in all parts. And because it is custom for the archbishop to celebrate Mass in the abbey, not with the aim of receiving something in return, not even an early morning meal ${ }^{432}$, but as if in remembrance of his consecration, which he is not allowed to accept unless in the

428. Cf. “...in fluxum superbiae ipso potentiae fastigio lenocinante corrumpitur”, Gregory the Great, Liber pastoralis curae, Migne, $P L, 1844-1864$, lxxvi, col. 35.

429. Cf. “...tales non pastores, sed mercenarios”, Bede, Homilies, Migne, PL, 1844-1864, xciv, col. 217.

430. This charter either never existed or is now lost. It is not to be found in MüHLBACHER, 1906. It was not unknown, however, for the abbey to create false documents concerning their independence from archiepiscopal jurisdiction, Arch. dép. Seine-Maritime, G 1272 and 14 H 151.

431. Nicholas, abbot of Saint-Ouen (1042-1092), and cousin of Duke William.

432. Literally, this phrase reads "not on account of anyone [in particular] or the change of his early morning meal", but the translation above, which was suggested to me by an anonymous reviewer of this article, seems to make more sense, and might relate to some unease within the abbey over the agreement reached between Archbishop Maurilius and Abbot Nicholas, which guaranteed the archbishop of Rouen would receive from the abbot seven gold coins for performing the Mass, while the cathedral clerks would receive four swine, one boar, one cow hide, forty hens, one hundred eggs, one hundred and twenty loaves of bread, and a measure and a half of wine: “... abbas autem archiepiscopo septem solidos dare debet, et clericis.iiii. frescengas, et unum verrem, et unam vaccam cum corio, et xl. gallinas, et.c. ova et.cxx. panes, et unum modium et dimidium vini", Allen, 2009, ii, Appendix G, $\mathrm{n}^{\circ} .57$. 
seat of the aforesaid church ${ }^{43}$, he received permission from the king and was returning quickly, with the abbot remaining to discharge various tasks. What more? The venerable day arrived, and the clergy of the cathedral gathered, as they were accustomed ${ }^{434}$, and as the archbishop had sent word to say he would soon be there, the great Mass was postponed. After some time, and by mutual agreement, it was decided to begin the Mass so that, while the archbishop might come, it was not to be shortened on such a solemn day. This was being done with so much attention to detail and devotion, that it was not surprising that the enemy of mankind had burned up with all his might to upset this joy. He thought that he would act for the greatest profit for himself, and that he would pollute that time with venom of his own malice, because he felt pain in being utterly ruined.

And so with the Kyrie with two trope verses ${ }^{435}$ having been finished, this brought about the Gloria in excelsis, which was begun by Richard, abbot of Sées ${ }^{436}$. The choir was completing it with his praises, and it was being weighed out in full in expectation of the archbishop, who arrived like a storm disturbing the grace of this ceremony. Full of indignation because he had not been waited for, he cursed everyone with scowling eyes and a raging mouth. Turning around he excommunicated the monks themselves, and by his authority and that of God he put an end to the office in progress by placing it under an interdict, and by expelling the abbot from the altar he forbid the office of the divine ministry. To see the feast day of such joy full of grief and folly, the many and great voices proclaiming it suddenly fell silent. The archbishop prepared to complete the office himself, and ordered his clerks to complete it from the place where it had been interrupted. We think we will omit nothing here, lest it should appear that we want to support one side over the other. The truth does not require the testimony of falsehood. The brothers, although they grieved that the grace of their great joy had been seized away from them, yielded to pontifical authority. Having laid aside the ornaments with which they were covered, they left the church in a great confusion, dispersed from one side to the other, and complained in turns to themselves about such an affront.

When suddenly somebody impatient of the mourning-it is not known if it was one of the monks, or one of their servants, who was angrier and had less of a capacity for judgement-hurried to the tower and began to ring the church's large bell. From there he went swiftly to the square, and shouted that the archbishop wanted to take the body of St. Ouen to the cathedral church. Everyone rushed out of their houses with a sword, others with axes, while others grabbed the first objects at hand, and in anger they burst into the church. Some of them acted with curiosity and

433. For discussion of the archbishop being consecrated in Saint-Ouen, see Pommeraye, 1662, p. 164$165,171-174$.

434. For the arrangements of the feast day of St. Ouen, see Allen, 2009, ii, Appendix G, $\mathrm{n}^{\circ} .57$.

435. The term "rithmis" most likely refers to a trope composed of two verse lines, which were probably hexameters, since these are the most common in tropes. I owe these observations to Professor Susan Rankin, who graciously answered my queries regarding the use of this terminology, and how it might best be translated (pers. comm.).

436. The abbot of Sées at this time was actually Robert (1060-1089). For his career, see GAZEAU, 2007, ii, p. 353-355. 
climbed into the vaulted galleries, while others stole the wooden boarding; they rummaged about as wild people might wish to. The majority were of the intention that, because the great happiness might have been cut short for them, the archbishop should not be allowed to complete it. The archbishop, becoming frightened by the approaching rabble which surrounded him on all sides, and feeling more threatened by those who were above him, fled from the altar towards the double doors of the monastery. Having escaped with difficulty he placed himself in their vicinity, and as the doors themselves had previously been closed, grabbed chairs and stools and heaped them all around himself. Yet some of his party seized candelabras, and with the candles and rods attacked the monks wildly, who pushed them back vigorously. It is shameful to say that the matter had to be decided in such a way on that day.

It has been well enough agreed that the merit of the saint helped everyone that day; he who restrained those raging hands, who saved the archbishop and his men from such danger, and who was able to avert such a great sin by a miracle that to everyone seemed very great. Indeed, suddenly a misty cloud invaded the sanctuary where the coffins of the saints were being held, upon which even the most curious eyes had wrongly gazed. The miracle was in agreement with the event. In fact, in various passages of the Scriptures a cloud sometimes represents the blindness of error, or sometimes the protection of the Lord, and it was precisely this that was being predicted in this particular cloud ${ }^{437}$. Certainly, it is a fact that a cloud was formed by the raging, just as smoke ascends, and it disturbed the serenity of the divine grace, just as it is certain that St. Ouen restrained the hand of the Lord, which was encouraged by their fault to strike, and thus protected them by his merits. An opposing statement takes nothing away from what has been said: only reason itself, depending on the whole, supports it ${ }^{438}$. The archbishop might have been allowed to consider the patience the Almighty returns ${ }^{439}$, if, restraining in his obstinacy, and by consideration of reason, he had regained his right mind. But the monstrosity of his behaviour did not stop in him entirely, so that imposing itself, it came upon him. The vicomte of the city ${ }^{440}$, therefore, having heard that the archbishop was encircled on all sides, and fearing that he would be the target of an illconsidered act, and would himself be accused of a crime, rounded up a military gang, all of whom he placed under the royal ban, hastened to help, and with no one resisting, nor himself lacking in inner confidence, removed the danger.

It was these acts of insanity that passed on so great a day. Can it be conceived what the reaction of the celestial court might have been, and how difficult it was for them to believe that the day of celebration of their eminent citizen Ouen had become thus confused and defiled, with his ministration forestalled? Can it be

437. E.g. "cumque descendisset Dominus per nubem stetit Moses cum eo invocans nomen Domini”, Exodus 34:5.

438. Cf. “...; deinde, quia testimonium quod profertur, de contextione totius Psalmi debet habere suffragium ut certe nihil sit quod ei refragetur, si non omnia suffragantur,...", De civitate Dei, Liber XVII, caput XV, in Migne, PL, 1844-1864, xli, col. 548.

439. Cf. “... altissimus enim est patiens redditor", Ecclesiasticus 5:4.

440. The vicomte in question was most likely Ansfredus (1055 × 1066-1081), Bouvris, 1986, p. 161. 
conceived what a misfortune this was, for such a great patron to have received absolutely nothing on this day from his sons which he could offer to appease the face of the Lord. As we are ignorant of the secrets of divine wisdom we leave them aside, and as men consider the human aspect. Among such a multitude of various ages, sexes and orders, we believe there was no lack of people who, of a carnal spirit, regretted having done evil less than not having found any way of stopping themselves from being deprived of the joy of the festival, and that those who were of better judgement blamed this tumult on their sins, lamented over their broken vows, and sighing after the forgiveness of their patron saint, were embarrassed of their acts.

The following day the monks selected some of them through whom the abbot might know what had occurred, and to suggest that he approach the duke about this. But an envoy of the archbishop had preceded them, who had deferred all the dishonour on the monks, and thus they returned with the business unfinished. The king was extremely irritated with them because of the impressions that were made by the archbishop and certain courtiers, yet reconsidering the thing he gave greater account to the archbishop's immoderate arrogance, and the ill-considered tumult that he had caused. Therefore, he ordered the archbishop to reconcile himself at once with the church. But when with sufficient anger and a reluctant heart he refused, the king ordered Michael, bishop of Avranches ${ }^{441}$, to unite the places in reconciliation, and he ignored his humiliation, saving his vengeance for the future. Therefore, he sent four monks, whom he had heard to be the instigators of the tumult, to the abbots of other monasteries, so far as it might make amends with the archbishop, and in their travelling they might atone for their sins ${ }^{442}$.

Yet after $a$ while, with the event considered and the abbot petitioning for their return, he recalled them and restored them to their church. For in all these matters the duke was always known to be of the same concern, lest the archbishop haughtily claim something from him under the guise of ecclesiastical vigour regarding the rights of this church. Indeed, after he was satisfied with the exile of these same brothers, he put the issue to deliberation, and gathered a council. And because the archbishop had entered the abbey in rage, had been the cause of all the disorder, and had refused to reconcile himself with the place, he fined the archbishop, by the judgement of his magnates, three hundred livres. By this punishment John was sufficiently acquitted of the fault committed, if internally he repented, and

441. Michael, bishop of Avranches (1068-1094). Theoderic does not indicate why the king chose the bishop of Avranches as mediator. It is possible, however, that since Michael was an Italian, and therefore did not have any ties of kinship in the duchy, he was seen as the best person to reconcile two institutions that were governed by relatives (Archbishop John and Abbot Nicholas were first cousins twice removed).

442. The names of these monks are preserved in two sets of annals. The Annals of Rouen state that the monk Nomenarus was sent to Fécamp, Benedict to Saint-Wandrille, and Ralph to Jumièges, whereas those of Jumièges claim that Wynemarus was sent to Jumièges, Benedict to Saint-Wandrille and Ralph to Fécamp, Chronicon Rotomagense..., p. 367; Annales de Jumièges..., p. 56. It would be logical to assume that, since the latter of these institutions actually received one of the monks in question, the order preserved in its annals is correct. 
if he did not neglect the Lord's mercy. But he maintained rancour in his heart against the monks of Saint-Ouen, and by that he caused himself more grief than calm. Three years passed and this affair gnawed away at his insides, and to use an appropriate example, he was like the fig tree of the Gospel: "Three years having passed, it did not bear fruits" ${ }^{443}$.

John had been struck with paralysis a few months before when the same festival, with time, came about. Since, however, he was now recovering from this sickness he came to the service, although because he could not celebrate the Mass himself, he entrusted this responsibility to Gilbert, bishop of Evreux ${ }^{44}$. John placed himself in the middle of the cantors, opposite the precentor. But when the reading of the Gospel began, this is an horrible thing to say, he was suddenly overwhelmed by internal moods which ran in his private parts, so that urine quickly soaked his linen tunic, then his leather garment, which it saturated entirely, and drenched the floor where he was standing. Then after the offerings of the faithful, it was not possible to keep this secret much longer, leaving the church-it is not convenient to say at what point he was embarrassed-he withdrew himself to his home.

From the time that this rumour had arrived in the ears of the people, who could judge, or who had the ability to say, in which or how many voices it was spread? But all unanimously celebrated the magnificence of the Lord and the merit of St. Ouen. They exclaimed that it was justifiable that John had been excluded so ignominiously from the present celebration, he who had previously disturbed it. Nobody has the right to be angry against us if we speak the truth, because we know of the examination of the universal Judge, in whose hands it is dreadful to fall $^{445}$, and we fear to incur this punishment, having stated the fault of others. But in fact to marvel at the judgements of God, which are like the great deep ${ }^{446}$, and which are proclaimed in so holy a man, who with pious affection always surrounds those who serve him with devotion, it is more of a sacrilege to hide ungratefully silent, as it is said, of respect. In addition, it is a great invitation to piety to think that it is necessary to strive continuously to serve the Lord in fear, and to rejoice, but with trembling ${ }^{447}$. Ponder soberly what a resplendent temple we ought to present to Him in ourselves, if such zeal is expressed in external worship in visible temples ${ }^{448}$. The Lord does not choose the inhabitants because of the place, but the place because of its inhabitants ${ }^{449}$.

443. Luke 13:9.

444. Gilbert, bishop of Évreux (1071-1112). John suffered his attack of apoplexy in late July 1077, OV, iii, p. 16-18. The presence of the bishop of Évreux was already determined by the agreement concerning the feast day celebrations mentioned above in n. 432.

445. Cf. "horrendum est incidere in manus Dei viventis", Hebrews 10:31.

446. Cf. "iustitia tua sicut montes Dei iudicia tua abyssus multa homines et iumenta salvabis Domine", Psalms 35:7.

447. Cf. "servite Domino in timore et exultate ei in tremore", Psalms 2:11.

448. I have translated here the visibilibus, "visible", published incorrectly by Mabillon, rather than the invisibilibus, "invisible", which appears in the manuscript, and which only Martène printed correctly, as it is probably what the scribe meant.

449. Cf. "verum non propter locum gentem sed propter gentem locum Dominus elegit", Maccabees II $5: 19$. 
Therefore, to return to the issue at hand, John worked three more years in infirmity, so much so that he could no longer discharge the duties of his office. Therefore, by royal authority, all having been consulted, he yielded the episcopate and withdrew to one of his own lands, called Saint-Philbert ${ }^{450}$, where he lived for some time. In the twelfth year of his pontificate, entering the way where all flesh goes, he left this life. He was thereupon brought back to his own see, however, and was buried with honour in his own church on 9 September ${ }^{451}$.

He was succeeded, or rather preceded ${ }^{452}$, since two months before his death Dom William, abbot of the monastery of $\mathrm{Caen}^{453}$, was enthroned with apostolic authority ${ }^{454}$, then by royal investiture and then finally by common election. He is said to be a sound man and of a noble family, and to be distinguished in excellence of manners.

\section{Bibliography}

Allen, Richard, The Norman episcopate, 989-1110, unpublished PhD thesis, 2 vol., University of Glasgow, 2009, xvi-855 p. (dactyl.).

Allen, Richard, “'A proud and headstrong man': John of Ivry, bishop of Avranches and archbishop of Rouen, 1060-79", Historical Research, (forthcoming; early view).

ALLEN, Richard, "The Acta archiepiscoporum Rotomagensium and urban ecclesiastical rivalry in eleventh-century Normandy", in Cathedrals, communities and conflict, 1000-130o, Paul Dalton (dir.), (forthcoming).

Annalis historia brevis sive Chronica monasterii S. Stephani Cadomensis, in GILES, 1845, p. 161-174.

Annales Uticenses, in Le Prévost, 1838-1855, v, p. 139-173.

Arnoux, Mathieu, "Before the Gesta Normannorum and beyond Dudo: some evidence on early Norman historiography", Anglo-Norman Studies, 22, 1999, p. 29-48.

BATES, David, Odo, bishop of Bayeux, 1049-1097, unpublished PhD thesis, University of Exeter, 1970, v-344 p. (dactyl.).

BAtes, David, Normandy before 1066, London, Longman, 1982, xx-287 p.

BATES, David, (ed.), Regesta regum Anglo-Normannorum: the Acta of William I, 10661087, Oxford, Clarendon Press, 1998, xxxviii-1153 p.

450. Saint-Philbert-sur-Risle, Eure, cant. Montfort-sur-Risle. For discussion of John's inheritance, see Gazeau, 1995, p. 139-147.

451. He was buried in the baptistery of his cathedral, on the north side, in a tomb of white marble. Orderic Vitalis preserved his epitaph, which contradicts the AAR and says John died on 9 September, $O V$, iii, p. 22. A stone tomb was found in a chapel during nineteenth-century excavations that was believed to be John's, SAUVAGE, 1889, p. 22.

452. I have translated here the praecessit ("preceded") published incorrectly by Migne and Mabillon, rather than the processit ("proceeded") which appears in the manuscript, and which only Martène printed correctly, as it is likely what the scribe meant.

453. William Bona Anima (1079-1110).

454. William actually encountered resistance from the pope concerning his election, since he was the son of a priest, JAFFé, $1885-1888, \mathrm{i}, \mathrm{n}^{\circ}$. 380. The letter is dated 23 September 1079. 
BauduIn, Pierre, La première Normandie ( $X^{e}-X I^{e}$ siècles): sur les frontières de la haute Normandie, Caen, PUC, 2004, $469 \mathrm{p}$.

BAylé, Maylis, "Les évêques et l'architecture normande au XIe siècle", in Les évêques normands du XI siècle, 1995, Caen, PUC, Pierre Boukt et François NeveUx (dir.), p. 151-172.

Beaurepaire, François de, Les noms des communes et anciennes paroisses de la SeineMaritime, Paris, 1979, viii-18o p.

Bessin, Guillaume (ed.), Concilia Rotomagensis provinciae, Rouen, François Vaultier, 1717, [8], viii, 267, 632, 70, [2] p.

BoüArd, Michel de, "Sur les origines de la Trêve de Dieu en Normandie", Annales de Normandie, 9, 1959a, p. 169-189.

BoüARD, Michel de, "Notes et hypothèses sur Maurille, moine de Fécamp, et son élection au siège métropolitain de Rouen”, in L'abbaye bénédictine de Fécamp. Ouvrage scientifique du XIII centenaire (658-1958), 4 vol., Fécamp, 1959b, i, p. 81-92.

Bouvris, Jean-Michel, “Contribution à une étude de l'institution vicomtale en Normandie au $\mathrm{XI}^{\mathrm{e}}$ siècle. L'exemple de la partie orientale du duché: les vicomtes de Rouen et de Fécamp", in Autour du pouvoir ducal normand $X^{e}-X I I^{e}$ siècles, Cahier des Annales de Normandie, 17, Caen, 1985, p. 149-174.

Bouvris, Jean-Michel, "L'école capitulaire de Rouen au XI siècle”, Études normandes, 3,1986, p. 89-103.

Brinkworth, Anne, The archbishops of Rouen, 1037-1110, unpublished M.Litt. dissertation, University of Bristol, 1966, ii-389 p.

Burgess, Glynn (ed.), Wace. The Roman de Rou, St. Helier, Société Jersiaise, 2002, li$408 \mathrm{p}$.

Certain, Eugène de (ed.), Les miracles de Saint Benoît, Paris, Société de l'histoire de France, $1858, \mathrm{xl}-390 \mathrm{p}$.

Chenesseau, Georges, L'Abbaye de Fleury à Saint-Benoit-sur-Loire, son histoire, ses institutions, ses édifices, Paris, 1931, xi-243 p.

Chibnall, Marjorie (ed.), The Ecclesiastical History of Orderic Vitalis, 6 vol., Oxford, Clarendon Press, 1969-1980, xvi-386 p., xliii-409 p., xxviii-408 p., xliii-393 p., xix413 p. and xxvii-611 p. [ref. as OV]

Chronicon Rotomagense, in LABBÉ, 1657, i, p. 364-39o.

Constable, Giles (ed.) and Smith, Bernard (trans.), Three treatises from Bec on the nature of monastic life, Toronto, University of Toronto Press, 2008, x-179 p.

Cowdrey, Herbert E.J., "Bishop Ermenfrid of Sion and the penitential ordinance following the battle of Hastings", Journal of Ecclesiastical History, 20, 1969, p. 225242.

Delamare, René (ed.), Le De officiis ecclesiasticis de Jean d'Avranches, archevêque de Rouen (1067-1079), Paris, A. Picard, 1923, clii-83 p.

Delisle, Léopold, “Canons du concile tenu à Lisieux en 1064", Journal des Savants, 1901, p. 516-521.

Devos, Cédric, Miracles, images et espace sacré en Normandie du XI au milieu du $X I I^{e}$ siècle. Le culte marial: les Miracula ecclesiae Constantiensis, mémoire de maîtrise, Université Libre de Bruxelles, 2007 (dactyl.). 
DiARD, Olivier and GaZEAu, Véronique, "Histoire et chant liturgique en Normandie au XI ${ }^{\mathrm{e}}$ siècle: les offices propres particuliers des diocèses d'Évreux et de Rouen”, Annales de Normandie, 53, 2003, p. 195-223.

Divi Ioannis Chrysostomi, Archiepiscopi Constantinopolitani, in totum Geneseos librum homiliae sexagintasex, Basel, 1523.

Douglas, David, William the Conqueror: the Norman impact upon England, London, 1964, xii-476 p.

Duchesne, Louis, Fastes épiscopaux de l'ancienne Gaule, 3 vol., Paris, A. Fontemoing, 1907-1915, vii-376 p., 488 p. and 270 p.

Dudo of Saint-Quentin, De moribus et actis primorum Normanniae ducum, Jules LAIR (ed.), Mémoires de la Société des antiquaires de Normandie, 23, 1865, 317 p.

Dunbabin, Jean, "The Maccabees as exemplars in the tenth and eleventh centuries", The Bible in the medieval world: essays in memory of Beryl Smalley, Katherine WALsH and Diana Wood (dir.), Oxford, 1985, p. 31-41.

Fauroux, Marie (ed.), Recueil des actes des ducs de Normandie de 911 à 1066, Mémoires de la Société des antiquaires de Normandie, 36, 1961, 560 p.

Foreville, Raymonde, "The synod of the province of Rouen in the eleventh and twelfth centuries", in Church and government in the middle ages: essays presented to C.R. Cheney on his 7oth birthday, C.N.L. Brooke et al. (dir.), Cambridge, Cambridge University Press, 1976, p. 19-39.

Gallia Christiana in provincias ecclesiasticas distributa, 16 vol., Paris, Victor Palme, 1865-1870.

Gazeau, Véronique, "Le patrimoine d'Hugues de Bayeux (c. 1011-1049)", in Les évêques normands du XI siècle, 1995, Caen, PUC, Pierre Bouet et François Neveux (dir.), p. 139-147.

Gazeau, Véronique, Normannia monastica, 2 vol., Caen, Publications du CRAHM, 2007, xiii-492 p. and vi-403 p.

Gibson, Margaret (ed.), Vita Lanfranci, in Lanfranco di Pavia e l'Europa del secolo XI nel IX centenario della morte (1089-1989), Giulio D'OnOfrio (dir.), Rome, Herder, 1993, p. 659-715.

Giles, John (ed.), Beati Lanfranci archiepiscopi Cantuariensis opera, 2 vol., Oxford, 1844 .

Giles, John (ed.), Scriptores rerum Gestarum Willelmi Conquestoris, London, 1845, xiv-297 p.

Greenway, Diana (ed.), Fasti ecclesiae Anglicanae, 1066-130o. VI, York, London, Institute of Historical Research, 1999, xxxv-151 p.

Grotefend, Hermann (ed.), Taschenbuch der Zeitrechnung des Deutschen Mittelalters und der Neuzeit, 13th ed., Hanover, 1991, 222 p.

GuIllot, Olivier, "La conversion des Normands peu après 911: des reflets contemporains à l'historiographie ultérieure ( $\mathrm{X}^{\mathrm{e}}-\mathrm{XI}^{\mathrm{e}}$ siècles)", Cahiers de civilisation médiévale, 24, 1981, p. 101-116, 181-219.

Halphen, Louis (ed.), Recueil d'annales angevines et vendômoises, Paris, Alphonse Picard et fils, 1903, lxi-162 p. 
Herval, René, Origines chrétiennes. De la II Lyonnaise gallo-romaine à la Normandie ducale, $I V^{e}-X I^{e}$ siècles, Paris, A. et J. Picard et Cie, 1966, 157 p.

Hesbert, René-Jean (ed.), Antiphonale Missarum Sextuplex, Brussels, Vromant, 1935, cxxvi-256 p.

JACQUELINE, Bernard, "Institutions et état économico-social du diocèse de Coutances de 836 à 1093, d'après les Gesta Gaufridi du 'Livre noir' du chapitre coutançais", Revue historique de droit français et étranger, 58, 1980, p. 227-239.

JAFFÉ, Philip (ed.), Regesta pontificum Romanorum, 2 vol., Leipzig, 1885-1888, vol. 1, xxxi-919 p. ; vol. 2, viii-823 p.

Johnson, Charles and Cronne, Henry A. (eds.), Regesta regum Anglo-Normannorum, 1066-1154: Regesta Henrici Primi, 1066-1135, Oxford, Clarendon Press, 1956, xlvi-454 p.

Keats-Rohan, Katharine S.B. (ed.), The cartulary of the abbey of Mont-Saint-Michel, Donington, Shaun Tyas, 2006, xiii-319 p.

KRUSCH, Bruno (ed.), Gregory of Tours, Libri historiarum X, MGH: SS rer. Merov., 1.1, Hanover, 1937, xlii-641 p.

Kurze, Friedrich, (ed.), Annales regni Francorum inde ab a. 741 usque ad a. 829, MGH: SS rer. Germ., 6, Hanover, 1895, xx-204 p.

LaвbÉ, Philippe (ed.), Novae bibliothecae manuscriptorum librorum, 2 vol., Sebastien Cramoisy, Paris, 1657, [32]-808 [i.e. 788]-[43] p. ; [20]-820 [i.e. 824]-[56] p.

La cathédrale de Rouen, seize siècles d'histoire, J.-P. ChAline (dir.), Rouen, 1996, 280 p.

LAPORTE, Jean (ed.), Les annales de l'abbaye Saint-Pierre de Jumièges. Chronique universelle des origines au XIII ${ }^{e}$ siècle, Rouen, Imprimerie Lecerf, 1954, 128 p.

Le Cacheux, Marie-Josèphe, Histoire de l'Abbaye de Saint-Amand de Rouen: des origines à la fin du XVI siècle, Caen, Société d'impression de Basse-Normandie, 1937, $292 \mathrm{p}$.

LelÉGARD, Marcel, "La cathédrale et la tombe de Geoffroi d’après le Livre noir de Coutances", in Les évêques normands du XI $I^{e}$ siècle, Pierre Bouet and François Neveux (dir.), Caen, PUC, 1995, p. 295-301.

Le Maho, Jacques, "Victrice de Rouen et l'archéologie; quelques observations nouvelles sur la cathédrale et son environnement architectural au IV ${ }^{\mathrm{e}}$ siècle", Bulletin des amis des monuments rouennais, 1991, p. 7-19.

Le Maho, Jacques, "La production éditoriale à Jumièges vers le milieu du $\mathrm{X}^{\mathrm{e}}$ siècle", Tabularia 'Études', 1, 2001, p. 11-32.

Le Prévost, Auguste (ed.), Orderici Vitalis Angligenae, coenobii Uticensis monachi, Historiae ecclesiasticae libri tredecim, 5 vol., Paris, Société de l'histoire de FranceJ. Renouard, 1838-1855, 462 p., 476 p., 624 p., 500 p. and cviii-532 p.

Les évêques normands $d u X I^{e}$ siècle, Pierre Bouet et François Neveux (dir.), Caen, PUC, 1995, $330 \mathrm{p}$.

Lifshitz, Felice, The dossier of Romanus of Rouen: the political uses of hagiographical texts, unpublished $\mathrm{PhD}$ thesis, Columbia University, 1988, 516 p. (dactyl.). 
Lifshitz, Felice, "The Acta archiepiscoporum Rotomagensium: a monastery or cathedral product?", Analecta Bollandiana, 108, 1990, p. 337-347.

Lifshitz, Felice, The Norman conquest of pious Neustria: historiographic discourse and saintly relics, 684-109o, Toronto, Pontifical Institute of Mediaeval Studies, 1995a, xii-324 p.

Lifshitz, Felice, “The migration of Neustrian relics in the Viking Age: the myth of voluntary exodus, the reality of coercion and theft", Early Medieval Europe, 4, 1995b, p. 175-192.

Lifshitz, Felice, "La Normandie carolingienne: essai sur la continuité, avec utilisation de sources négligées", Annales de Normandie, 48, 1998, p. 505-524.

Mabillon, Jean (ed.), Veterum analectorum tomus I [-IV], 4 vol., Paris, Louis Billaine, $1675-1685,[16], 437,[10] ;[24], 694,[30] ;[20], 544,[38] ;[16], 648,[30] \mathrm{p}$.

Mabillon, Jean (ed.), Vetera analecta, Paris, Montalant, 1723, [63]-573-[17] p.

Mansi, Giovanni (ed.), Sacrorum conciliorum nova et amplissima collectio, 53 vol., Venice, $1757-1798$.

MARTÈne, Edmond (ed.), Veterum scriptorum collectio nova, Rouen, Guillaume Behourt, 1700, 328 p. and 344 p.

MARTÈne, Edmond (ed.), De antiquis ecclesiae ritibus, 4 vol., Bassan, 1788.

Martimort, Aimé-Georges, La documentation liturgique de dom Edmond Martène: étude codicologique, Studi e Testi 279, Vatican City, 1978, 696 p.

Migne, Jacques-Paul (ed.), Patrologia latina cursus completus, 221 vol., Paris, 18441864 .

Morlet, Marie-Thérèse (ed.), Les noms de personne sur le territoire de l'ancienne Gaule du VI $I^{e}$ au XII siècle, 3 vol., Paris, Éditions du CNRS, 1965-1987, 237 p., 203 p. and 563 p.

Mühlbacher, Engelbert (ed.), Die Urkunden Pippins, Karlmanns und Karls des Großen, MGH: DD Kar. 1, Hanover, 1906, xi-581 p.

Musset, Lucien, “Aux origines d'une classe dirigeante: les Tosny, grands barons normands du X' au XIII ${ }^{\mathrm{e}}$ siècle", Francia, 5, 1977, p. 45-80.

Nortier, Geneviève, Les bibliothèques médiévales des abbayes bénédictines de Normandie: Fécamp, Le Bec, Le Mont Saint-Michel, Saint-Évroul, Lyre, Jumièges, SaintWandrille, Saint-Ouen, Paris, P. Lethielleux, 1971, 252 p.

Pommeraye, Jean-François, Histoire de l'abbaye royale de S. Ouen de Rouen, Rouen, R. Lallemant \& L. du Mesnil, 1662, 500-96-100 p.

Poncelet, Albert, "Vita Sancti Gildardi episcopi Rothomagensis et ejusdem translatio Suessiones anno 838-840 facta", Analecta Bollandiana, 8, 1889, p. 389-406.

PoréE, Adolphe-André (ed.), Chronique du Bec et chronique de François Carré, Rouen, Société de l'histoire de Normandie, 1883, xxvii-287 p.

Pоттнаsт, August, Bibliotheca historica medii aevi: Wegweiser durch die Geschichtswerke des europäischen Mittelalters bis 1500, Berlin, W. Weber, 1896, cxlv-320 p.

http://www.unicaen.fr/mrsh/craham/revue/tabularia/print.php?dossier=sources\&file=09allen.xml 
Recueil des historiens des Gaules et de la France, 24 vol., Paris, Victor Palme, 18691904 .

Rivet de la Grange, Antoine et al. (eds.), Histoire littéraire de la France par des religieux bénédictins de la congrégation de S. Maur, 41 vol., Paris, 1733-

SAuvage, Eugène Paul, "Elenchi archiepiscoporum Rothomagensium”, Analecta Bollandiana, 8, 1891, p. 406-434.

Sauvage, Eugène Paul, Les Souterrains de la cathédrale de Rouen, Rouen, 1889, 24 p.

Sноркош, Leah, History and community: Norman historical writing in the eleventh and twelfth centuries, Washington, D.C., Catholic University Press, 1997, 327 p.

SociétÉ Des Bollandistes (ed.), Acta sanctorum quotquot toto orbe coluntur, 67 vol., 1863-1983. [ref. as AASS]

Somerville, Robert, “The case against Berengar of Tours - a new text”, Studi Gregoriani, 9,1972 , p. 55-75.

Sот, Michel, Gesta episcoporum, gesta abbatum, Brepols, Turnhout, 1981, 57 p.

Southern, Richard (ed.), Eadmeri monachi Cantuariensis vita sancti Anselmi archiepiscopi Cantuariensis, Oxford, Clarendon Press, 1972.

Spear, David (ed.), The personnel of the Norman cathedrals during the ducal period, 911-1204, London, Institute of Historical Research (coll. Fasti Ecclesiae Anglicanae. 1066-1300), 2006, xl-334 p.

Tessier, Georges, (ed.), Recueil des actes de Charles II le Chauve, roi de France, 3 vol., Paris, Imprimerie nationale, 1952, xiii-564, 672 and $423 \mathrm{p}$.

TrÂN-Duc, Lucile, "Les princes normands et les reliques ( $\mathrm{X}^{\mathrm{e}}-\mathrm{XI}{ }^{\mathrm{e}}$ siècles): contribution du culte des saints à la formation territoriale et identité d'une principauté", in Reliques et sainteté dans l'espace médiéval, Jean-Luc Deuffic (dir.), Saint-Denis, 2006 (Pecia: resources en médiévistique, v. 8-11), p. 525-561.

VACANDARD, Elphège, "Un essai d'histoire des archevêques de Rouen au XIe siècle”, Revue catholique de Normandie, 3, 1893, p. 117-127.

VACANDARD, Elphège, Vie de Saint Ouen, évêque de Rouen (641-684): étude d'histoire mérovingienne, Paris, 1902, xxi-394 p.

Van der Straeten, Joseph, "Vie inédite de saint Hugues, évêque de Rouen", Analecta Bollandiana, 87, 1969, p. 215-260.

Violette, Louis, L'église métropolitaine de Rouen pendant la première période normande ( $\mathrm{X}^{e}-\mathrm{XI} \mathrm{I}^{e}$ siècles), unpublished $\mathrm{PhD}$ thesis, 2 vol., Université de Paris-X, 1994, (dactyl.).

Violette, Louis, "Le problème de l'attribution d'un texte rouennais du XI' siècle: les Acta Archiepiscoporum Rothomagensium”, Analecta Bollandiana, 115, 1997a, p. 113-129.

Violette, Louis, “Une entreprise historiographique au temps de la réforme grégorienne: les Actes des archevêques de Rouen", Revue d'histoire de l'église de France, 83, 1997b, p. 343-365. 
Violette, Louis, "Une étape décisive dans l'éveil des activités historiographiques au service du siège de Rouen: l'épiscopat de Maurille, moine de Fécamp", Tabularia 'Études', 3, 2003, p. 57-67.

Violette, Louis, “Orderic Vital, historiographe des archevêques de Rouen”, in 3961996. XVI centenaire de la cathédrale Notre-Dame de Rouen: colloque international, 5,6, et 7 décembre 1996, Rouen, 2005, p. 74-85.

Williams, George, Norman Anonymous of 1100 A.D., Cambridge, MA, 1951, xiii-236 p.

Wilson, Henry (ed.), The Benedictional of archbishop Robert, Henry Bradshaw Society, London, 1903, xxii-210 p.

Yver, Jean, "Les premières institutions du duché de Normandie", in I normanni e la loro espansione in Europa nell'alto medioevo, Spoleto, 1969, p. 299-366.

http://www.unicaen.fr/mrsh/craham/revue/tabularia/print.php?dossier=sources\&file=09allen.xml 